I NTER NATIONAL MONETARY FUND

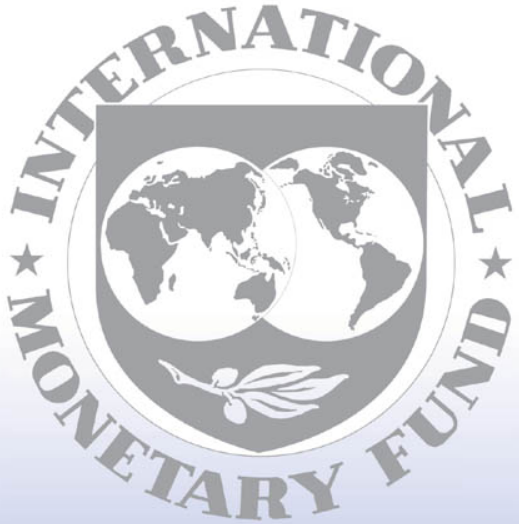

Staff

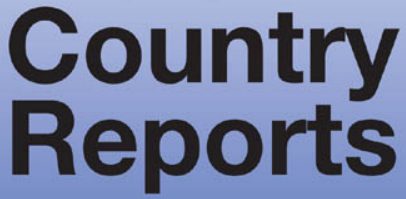




\section{Israel: Detailed Assessment of Observance of Basel Core Principles for Effective Banking Supervision}

This paper was prepared based on the information available at the time it was completed in March 2012. The views expressed in this document are those of the staff team and do not necessarily reflect the views of the government of Israel or the Executive Board of the IMF.

The policy of publication of staff reports and other documents by the IMF allows for the deletion of market-sensitive information.

Copies of this report are available to the public from

International Monetary Fund $\bullet$ Publication Services

700 19th Street, N.W. • Washington, D.C. 20431

Telephone: (202) 623-7430 • Telefax: (202) 623-7201

E-mail: publications@imf.org • Internet: http://www.imf.org

\section{International Monetary Fund Washington, D.C.}


FinANCIAL SECtor Assessment Program UpdATE

\section{ISRAEL}

BASEl Core PrinciPles For EFFECTIVE BANKING SUPERVISION

\section{DETAILED ASSESSMENT OF OBSERVANCE}

MARCH 2012

INTERNATIONAL MONETARY FUND

MONETARY AND CAPITAL MARKETS DEPARTMENT 
This page intentionally left blank

(C)International Monetary Fund. Not for Redistribution 


\section{Contents}

I. Summary, Key Findings, and Recommendations

$\underline{3}$

Introduction

.3

Information and methodology used for assessment.....

Institutional and Macro-Prudential Setting, and Market Structure

Preconditions for Effective Banking Supervision

Main findings

Recommended action plan and authorities' response

II. Detailed Assessment

Tables

1. Summary Compliance with the Basel Core Principles

2. Recommended Action Plan to Improve Compliance with the Basel Core Principles .........15

3. Detailed Assessment of Compliance with the Basel Core Principles. 


\section{SUMMARY, KEY FindingS, AND RECOMMENDATIONS}

\section{Banking sector regulation and supervision is generally in line with} international standards and stringent The authorities generally take a pro-active, stability-oriented approach. Regulations are generally up to date, a great deal of information is gathered and analyzed through on-site and off-site supervision, and the authorities demand prompt correction of any deficiencies detected in supervised institutions. In some areas, the authorities' regulation and practice goes well beyond the standard. Most remaining deficiencies relative to the standard are being addressed or are of relatively low materiality. Areas for improvement include the regulation and supervision of interest-rate risk, market risk, and liquidity risk; supervision of certain securities-related activities performed in Israel or abroad; and flexibility and autonomy in personnel management and budgets to attract and retain financial sector experts with the required skill mix.

\section{Introduction}

\section{The 2001 Israel FSAP undertook an assessment of compliance with the Basel} Core Principles for Effective Banking Supervision based on the 1999 methodology. Based on that methodology, it was judged that Israel was compliant with 17 of the 25 Core Principles, largely compliant with 6 (Objectives, autonomy and powers; investment criteria; loan evaluation; country and transfer risk; bank management; remedial issues), and materially noncompliant with two (CP15 on the prevention of money laundering and CP 24 on information sharing with foreign supervisors). One overriding feature of that assessment was that overall, the quality of implementation of supervision, both on-site and off-site, was good. The supervisors availed themselves of broad powers both to supervise and to set regulations, and to enforce them. The general recommendation was to make the legislation pertaining to banking more transparent.

\section{Since then, the Israeli banking system and the financial system more}

generally has been transformed (see below). Changes in the Israeli context, the external economy, and the international standards warrant the update.

\section{This Detailed Assessment of Observance Report was prepared as part of the}

FSAP Update mission to Israel, which took place November 6-21, 2011. The assessors were Thierry Bayle (Banque de France) and Joel Shapiro (formerly of the U.S. Federal Reserve). The FSAP Update conducted assessments of compliance with the International Association of Insurance Supervisors Insurance Core Principles (IAIS ICP); the International Organization of Securities Commissions and Overseers (IOSCO) Objectives and Principles of Securities Regulation; and the Committee on Payment and Settlement Systems (CPSS) Core Principles for Systemically Important Payment Systems. Extensive analysis was undertaken of vulnerabilities of the Israeli financial system following the 2008-09 global crises and the uncertain global environment at the time of the assessment; the development of macro-prudential oversight and policies; and the crisis management system. 


\section{Information and methodology used for assessment}

5. The assessment is based on several sources: (i) a comprehensive and critical self-assessment, received in October 2011; (ii) detailed interviews with staff from BOI and other government agencies on the current practice for on- and off-site supervision; (iii) reading of laws, regulations, and other documentation on the supervisory framework and on the structure and development of the Israeli financial sector, including a questionnaire response prepared by the authorities; (iv) reading of anonymous supervisory materials provided to the assessors during and after the fieldwork in Israel; (v) meetings with other authorities; and (vi) meetings with the banking industry as well as others such as academics and representatives of the accounting and audit profession. Specifically, the assessment team held extensive discussions with: staff from the BOI and in particular its Banking Supervision Department (BSD), the Ministry of Finance, other government agencies including the Capital Markets, Insurance and Savings Department (CMISD) of the MOF, the Israel Securities Authority (ISA), the Tel Aviv Stock Exchange (TASE), and the Israel Money Laundering and Terror Financing Prohibition Authority (IMPA), and private sector participants in the banking and financial markets.

\section{The assessors had the full cooperation from the Israeli authorities and} received all information necessary for the assessment. The team extends its thanks to the staff of the authorities for their participation in the process, their openness, and their hospitality, and to the private sector representatives with whom they had a chance to meet.

\section{The assessment has been conducted in accordance with the guidelines} described in the Core Principles (CP) Methodology published in October 2006 by the Basel Committee on Banking Supervision (BCBS). ${ }^{1}$ It assessed compliance with both the "essential" and the "additional" criteria, but the ratings assigned were based on compliance with the "essential" criteria only. The methodology requires that the assessment be based on (i) the legal and other documentary evidence; (ii) the work of the supervisory authority; as well as (iii) the implementation in the banking sector. Full compliance requires that all these three prerequisites are met. The guidelines allow that a country may fulfill the compliance criteria in a different manner from the ones suggested as long as it can prove that the overriding objectives of each $\mathrm{CP}$ are reached. Conversely, countries may sometimes be required to fulfill more than the minimum standards, e.g., due to structural weaknesses in that country. The Methodology also states that the assessment is to be made on the factual situation of the date when the assessment is completed. However, where applicable, the assessors made note of regulatory initiatives, which have yet to be completed or implemented.

8. The assessment of compliance of each principle should be made based on the following four-grade scale: compliant, largely compliant, materially noncompliant, and noncompliant. A "not applicable" grading can be used under certain circumstances.

\footnotetext{
${ }^{1}$ http://www.bis.org/publ/bcbs130.htm.
} 
- Compliant - A country will be considered compliant with a Principle when all essential criteria applicable for this country are met without any significant deficiencies. There may be instances, of course, where a country can demonstrate that the Principle has been achieved by other means. Conversely, due to the specific conditions in individual countries, the essential criteria may not always be sufficient to achieve the objective of the Principle, and therefore other measures may also be needed in order for the aspect of banking supervision addressed by the Principle to be considered effective.

- $\quad$ Largely compliant - A country will be considered largely compliant with a Principle whenever only minor shortcomings are observed which do not raise any concerns about the authority's ability and clear intent to achieve full compliance with the Principle within a prescribed period of time. The assessment "largely compliant" can be used when the system does not meet all essential criteria, but the overall effectiveness is sufficiently good, and no material risks are left unaddressed.

- Materially non-compliant - A country will be considered materially noncompliant with a Principle whenever there are severe shortcomings, despite the existence of formal rules, regulations and procedures, and there is evidence that supervision has clearly not been effective, that practical implementation is weak, or that the shortcomings are sufficient to raise doubts about the authority's ability to achieve compliance. It is acknowledged that the "gap" between "largely compliant" and "materially non-compliant" is wide, and that the choice may be difficult. On the other hand, the intention has been to force the assessors to make a clear statement.

- $\quad$ Noncompliant - A country will be considered non-compliant with a Principle whenever there has been no substantive implementation of the Principle, several essential criteria are not complied with or supervision is manifestly ineffective.

- In addition, a Principle will be considered not applicable when, in the view of the assessor, the Principle does not apply given the structural, legal and institutional features of a country.

9. An assessment of compliance with the BCPs is not, and is not intended to be, an exact science; reaching conclusions require judgments by the assessment team. Banking systems differ from one country to another, as do domestic circumstances. Also, banking activities are changing rapidly around the world after the crisis and theories, polices, and best practices are rapidly evolving. Nevertheless, by adhering to a common agreed methodology, the assessment should provide the Israeli authorities with an internationally consistent measure of quality of their banking supervision in relation to the 2006 Revision of the BCPs, ${ }^{2}$ which are internationally recognized as minimum standards.

\footnotetext{
${ }^{2}$ http://www.bis.org/publ/bcbs129.htm.
} 
10. For completeness' sake, it should be noted that the ratings assigned during this assessment are not necessarily directly comparable to the ones assigned in terms of an FSAP performed using the pre-2006 BCP Methodology. Differences may stem from the fact that the bar to measure the effectiveness of a supervisory framework was raised by the 2006 update of the BCP Methodology, as well as by lessons drawn from the financial crisis that may have a bearing on supervisory practices.

\section{Institutional and Macro-Prudential Setting, and Market Structure}

11. The main financial institutions are banks and insurance companies; there is a large and active market in shares, corporate bonds, and government bonds; savers have available a variety of pension, provident, and mutual funds. The Bachar reform that began in mid-2005 forced banks to divest most non-commercial banking activities, such as mutual funds, insurance, pension, and provident funds; the banks today focus on traditional banking business. As a result, the non-bank financial sector has grown rapidly, now playing a larger role in credit markets. Nonetheless, banks still play an important financial intermediary role, with their assets amounting to about 140 percent of GDP. Most banks have relatively little overseas activity; dollarization has been greatly reduced. Foreign institutions play a minor role, and with, a few exceptions, foreign ownership of Israeli institutions is limited. The banking and insurance sectors are concentrated.

\section{Financial supervision responsibilities in Israel are shared among several} agencies. The Bank of Israel (BOI) and specifically its Banking Supervision Department (BSD) supervises banks. BOI is responsible also for payments system oversight. The Israel Securities Authority (ISA) oversees the securities sector, while the Commissioner of Capital Markets, Insurance, and Savings (CCMIS) at the Ministry of Finance (MOF) mainly deals with the insurance and pension sector. The Tel Aviv Stock Exchange (TASE) has some supervisory responsibilities for its members.

13. The supervisors cooperate on a regular basis. There exists memorandum of understandings (MOUs) among BOI, ISA, and CCMIS, but it only outlines basic information sharing agreement without reference to specifics, and does not specify supervisory corporation arrangements more broadly. The practice of cooperation, for example seems to be broadly satisfactory for normal times, but may be over-stretched in times of crisis or weak in anticipating common vulnerabilities. Cooperation and information exchange were indeed intensified during the global crisis.

\section{Recent developments}

14. The global crisis affected Israel's economy, but no domestic financial institution got into serious difficulties during the crisis. Banks have weathered the storm of the global crisis, although profitability suffered. In part, this reflected the characteristics of Israel's banking system, namely, banks' conservative management; limited inter-connectedness due to the small interbank and wholesale funding markets; lack of complex asset and securitized markets; and strong and intrusive bank supervision. Some insurance companies made losses, as did many investors in the various funds. The 
corporate bond market suffered especially large falls in prices, and new issuance came to a halt.

15. The authorities preempted the spread of financial stress with a slew of crisisintervention measures. BOI aggressively cut its policy interest rates, and expanded liquidity facilities. BSD tightened bank supervisory measures in areas of reporting, capital, and liquidity. In areas of capital markets, the MOF established various back-stop mechanisms, such as a "safety net" program for provident fund savings, a guarantee program to banks for raising capital, and the creation of the government-established investment funds ("Manof" funds); the ISA set up a debt settlement framework.

Furthermore, this episode led to the establishment of the Hodek committee, which in February 2010 presented a set of recommendations to the government to improve market transparency, conduct, and the corporate government of institutional investors.

16. At the time of the mission, the health of the financial sector was generally satisfactory. The average capital ratio for major Israeli banks reached 14 percent, while the Tier 1 capital ratio stood at around 8.5 percent. Banks profitability declined sharply in 2008, but has since recovered as loan loss provisions have decreased and net interest income has increased. Banks remain mainly deposit-funded, with customer deposits exceeding loans. Financial soundness indicators for insurance companies are currently generally satisfactory.

\section{Preconditions for Effective Banking Supervision}

\section{Sound and sustainable macroeconomic policies}

\section{Israel has a solid institutional framework supporting the conduct of sound} macro-economic policies. Monetary policy is based on an inflation targeting framework, and the BOI's independence has been recently strengthened following the enactment of the 2010 BOI Law. Budgetary policy too has been strengthened in recent years, with the establishment of a fiscal rule that gives credibility to the authorities' fiscal consolidation plan.

\section{A well-developed public infrastructure}

18. The Israeli legal framework for the financial sector and more generally is comprehensive and regularly updated.

19. The auditing and accounting rules applicable to financial institutions generally comply with international standards. Listed companies and most nonbank financial institutions have applied International Financial Reporting Standards (IFRS) since 2008. The Israeli banking system reports under BSD's directives and Israeli General Accepted Accounting Principles (GAAP), which is close to U.S. GAAP, with some IFRS elements for non-core activities.

20. The Israeli legislative framework with regard to the audit profession requires internal and external auditors to be independent in both fact and appearance. The Banking Ordinance, 1941 requires the appointment of internal auditor in a banking 
corporation, and stipulates the governance of the internal auditor, who is subjected to specific sections of the Internal Audit Law. Furthermore, the Companies Law and the Accountants Law assure the independence of external auditors, including qualification requirements. However, the audit profession is self-regulating.

\section{The judicial system, including that for bankruptcy and the enforcement of} property rights, is well-developed. The Israeli legal tradition is based mostly on English common law, which is reflected both in the nature of its corporate legislation and the role of the judiciary. The legal background and regulatory and institutional framework dealing with weak banks are stipulated in the Banking Ordinance, 1941, although there is no legal provision dedicated to bank bankruptcy.

22. The payment and settlement system is reliable and efficient. The BOI regulates Israel's payment systems. It operates the Zahav system (a real time gross settlement system), which is considered to be secure and fast. The Zahav system is linked to banks' paper-based clearing house $(\mathrm{BCH})$, the automated clearing house (Masav), and the Tel Aviv Stock Exchange (TASE) clearing house.

\section{Effective market discipline}

23. Competition is encouraged and the market is open to foreign participation. There are no significant non-prudential barriers to entry by domestic or foreign firms.

24. A freeze in capital markets in late 2008 revealed weaknesses in disclosure and transparency in non-bank financial institutions. Efforts to improve the quality and timeliness of disclosure are underway, for example, through the amendments to the Companies Law in August 2011 that strengthens corporate governance requirements, aimed at enhancing bondholder protection. Also, the implementation of the "Hodek committee" recommendations (such as the imposition of minimum covenants for new bond issues), and of similar provisions that the ISA imposed on mutual fund managers, should have improved the resilience of new corporate bond issues.

25. The corporate governance of financial institutions in Israel is governed by the Companies Law and the Securities Law. In addition, sectoral legislation has been introduced to regulate the operation of each financial sector, such as banks (the Banking Licensing Law, the Banking Ordinance, 1941, the Banking (Service to Costumer) Law and the BOI Law), mutual funds (Joint Investment Trust Law), provident funds (Provident Funds), and pension funds (Pension Counseling and Pension Market Law).

26. The basic principles of financial reporting are laid out in the Securities Law. The law addresses the contest of a prospectus, the prohibition against the use of insider information, and the penalties applicable for the breach of the law. The law also sets out the contents of annual reporting requirements for non-bank listed companies. To facilitate the disclosure in line with those required by the Securities Law, the ISA provides an online filing system which is accessible to the public. The Banking Ordinance, 1941 and BSD directives set out the contents of annual and quarterly financial reporting by banks. 


\section{Public safety nets}

27. Israel does not have formal deposit insurance. However, in the past, the government and the BOI provided an extensive degree of de facto protection to depositors. For example, in response to the public's increasing concern about deposits during the latest global crisis, the MOF stated that the BOI and the government would protect depositors. For the non-systemic bank failure cases in 1985 and 2001, the BOI compensated depositors almost in full. In the severe financial crisis of the early $1980 \mathrm{~s}$, the government nationalized the entire system, and depositors did not suffer any losses.

\section{Legal framework for supervision}

\section{The Israeli legal framework for banking supervision comprises legislation} and regulation at various levels. The primary legislation that underpins the power of BOI Governor and Supervisor to supervise and regulate banks is the BOI law, the Banking Ordinance, 1941, the Banking Licensing Law, and the Banking Service to Customer Law. To implement prudential requirements, BOI Supervisor has the power to issue Proper Conduct of Banking Business Directives, instructions, and letters.

\section{Main findings}

29. Table 1 provides an overview of the assessment on a principle by principle basis.

30. Objectives, independence, powers, transparency, and cooperation (CP1): There is a comprehensive set of laws and directives governing the supervision of the banking industry, although some of the legislation is old. The BOI has a great deal of de jure and de facto independence, and accountability mechanisms are in place. The influence of the MOF in the salary scale of BOI employees compromises its independence and raises questions about the long term capacity of the banking supervision staff.

31. Licensing and structure (CPs 2-5): The legal framework is clear relative to the types of banking and non-banking activities in which banking corporations may engage. While there have been few license applications in recent years, the legal framework, policies and processes are in place to evaluate the application for a bank license. The transfer of ownership is well defined in the law, and there are explicit definitions for controlling interests, although these are contained in a policy rather than in law. The conditions for the acquisition of a non-bank financial institution in Israel could be set out more formally.

32. Prudential regulation and requirements (CPs 6-18): The regulatory framework is fairly comprehensive, but dense and complex. The capital adequacy framework is based on international standards for standardized approaches to credit, market and operational risk in Pillar I. Pillar II is a significant component of the capital adequacy requirements, though the process is somewhat informal. Credit and most other risks are subject to close and intensive scrutiny. BOI exerts close oversight of concentrations (single name, sectorial, geographic, collateral, and product). Areas for improvement 
include the regulation and supervision of interest-rate risk in the banking book, market risk, and liquidity risk.

33. Methods of ongoing banking supervision (CPs 19-21): BOI has implemented a risk-based approach to supervision, which is evolving as the supervisors gain experience with it. There is a mix of on-site and off-site supervision, with an extensive level of communication and cooperation between the two groups. There is an extensive array of reporting requirements for banks that provides a wide range of data and risk management information, both on a consolidated and unconsolidated basis. Appropriately, the information is used in the supervision process to evaluate risk and for other objectives.

34. Accounting and disclosure (CP 22): Disclosure requirements are very strict, and external auditors are employed to ensure that disclosure rules are adhered to. The authorities are planning to transition the banking system solely to IFRS standards by 2013 or later.

35. Corrective and remedial powers of supervisors (CP 23): At present there is a restrictive list of available remedies in the law, such as eliminating dividends, but the supervisor should be able to apply remedial measures that reflect the level and severity of the deficiencies. Expansion of powers and strategies concerning the resolution of a problem bank is under consideration, which would enable BOI to have the time and the power to develop more creative approaches to resolving a bank than exists in the law at present.

36. Consolidated and cross-border banking supervision (CPs 24-25): The BOI has developed an overall satisfactory program of consolidated supervision, but there is a gap in the supervision of certain securities-related activities engaged in by banking corporations. The BOI engages in host-home country relationships commensurate with the size and complexity of the operations of Israeli banks operating abroad. Foreign bank operations in Israel are at a relatively low level, and home-host relations are more ad hoc in nature, reflecting the size and materiality of these banking operations. 
Table 1. Israel: Summary Compliance with the Basel Core Principles

\begin{tabular}{|c|c|c|}
\hline Core Principle & Grading & Comments \\
\hline $\begin{array}{l}\text { 1. Objectives, } \\
\text { independence, } \\
\text { powers, } \\
\text { transparency, and } \\
\text { cooperation }\end{array}$ & Compliant & $\begin{array}{l}\text { There is a comprehensive set of laws and directives governing } \\
\text { the supervision of the banking industry. The legal framework } \\
\text { provides sufficient supervisory tools to require banking } \\
\text { corporations to comply with laws and directives, and there are } \\
\text { adequate provisions in the law to facilitate consolidated and } \\
\text { cross-border supervision. Certain provisions of the law should } \\
\text { be more flexible to enable the Supervisor of Banks to respond } \\
\text { in an appropriate manner, including provisions relating to the } \\
\text { expansion of permissible activities, developing appropriate } \\
\text { enforcement actions for deficiencies in banks, and responding } \\
\text { to the intervention in a problem bank. }\end{array}$ \\
\hline $\begin{array}{l}1.1 \\
\text { Responsibilities } \\
\text { and objectives }\end{array}$ & $\begin{array}{l}\text { Largely } \\
\text { Compliant }\end{array}$ & $\begin{array}{l}\text { The set of laws and regulations is comprehensive. However, } \\
\text { banking laws have not been amended as promptly as would be } \\
\text { desirable (e.g., regarding banks' engagement with certain } \\
\text { derivatives products). Decades of amendments have led to a } \\
\text { somewhat piecemeal set of provisions. }\end{array}$ \\
\hline $\begin{array}{l}1.2 \\
\text { Independence, } \\
\text { accountability and } \\
\text { transparency }\end{array}$ & $\begin{array}{l}\text { Largely } \\
\text { Compliant }\end{array}$ & $\begin{array}{l}\text { The BOI has a great deal of de jure and de facto } \\
\text { independence, and accountability mechanisms are in place. } \\
\text { The influence of the MOF in the salary scale of BOI employees } \\
\text { compromises its independence and raises questions about the } \\
\text { long term capacity of the banking supervision staff. }\end{array}$ \\
\hline $\begin{array}{l}1.3 \text { Legal } \\
\text { framework }\end{array}$ & Compliant & $\begin{array}{l}\text { The Banking Ordinance, } 1941 \text {, and the Banking (Licensing) } \\
\text { Law, } 5741 \text { - } 1981 \text { provide an overall satisfactory legal } \\
\text { framework for the supervision of banks, and are complemented } \\
\text { with a compendium of detailed directives. }\end{array}$ \\
\hline $1.4 \mathrm{~L}$ & Compliant & $\begin{array}{l}\text { The Supervisor of Banks has sufficient powers in the law, and } \\
\text { an appropriate range of tools, to require banks to comply with } \\
\text { banking laws and regulations. }\end{array}$ \\
\hline $\begin{array}{l}1.5 \text { Legal } \\
\text { protection }\end{array}$ & Compliant & $\begin{array}{l}\text { There are adequate protections in the law to indemnify bank } \\
\text { supervisors against litigation in the proper conduct and } \\
\text { execution of their responsibilities as bank supervisors. }\end{array}$ \\
\hline 1.6 Cooperation & Compliant & $\begin{array}{l}\text { A satisfactory framework for cooperation on supervisory issues } \\
\text { and the exchange of information exists between BOI and other } \\
\text { financial regulators in Israeli and important foreign supervisors. } \\
\text { Cooperative efforts and the exchange of information with other } \\
\text { Israeli financial regulators are maturing, as reflected in the } \\
\text { establishment of the Liaison Committee. }\end{array}$ \\
\hline $\begin{array}{l}\text { 2. Permissible } \\
\text { activities }\end{array}$ & $\begin{array}{l}\text { Largely } \\
\text { Compliant }\end{array}$ & $\begin{array}{l}\text { The legal framework is clear relative to the types of banking } \\
\text { and non-banking activities in which banking corporations may } \\
\text { engage. However, BOI must interpret the meaning of banking } \\
\text { activities very broadly in order to enable banking corporations } \\
\text { to engage in new products as they are introduced in the } \\
\text { market. The interpretation of the law enabling banks to engage } \\
\text { in derivative products is one such example of a broad } \\
\text { interpretation of the law. }\end{array}$ \\
\hline 3. Licensing criteria & Compliant & $\begin{array}{l}\text { The infrastructure is in place in terms of the legal framework, } \\
\text { policies and processes to evaluate such applications. }\end{array}$ \\
\hline
\end{tabular}




\begin{tabular}{|c|c|c|}
\hline Core Principle & Grading & Comments \\
\hline $\begin{array}{l}\text { 4. Transfer of } \\
\text { significant } \\
\text { ownership }\end{array}$ & Compliant & $\begin{array}{l}\text { The transfer of ownership is well defined in the law, and there } \\
\text { are explicit definitions for controlling interests, although these } \\
\text { are contained in a policy rather than in law. }\end{array}$ \\
\hline $\begin{array}{l}\text { 5. Major } \\
\text { acquisitions }\end{array}$ & $\begin{array}{l}\text { Largely } \\
\text { Compliant }\end{array}$ & $\begin{array}{l}\text { The law governing the acquisition of non-bank financial } \\
\text { companies is very restrictive, as it limits the type of such } \\
\text { companies in which a bank may operate. With the exception of } \\
\text { companies that may be engaged in permissible banking } \\
\text { activities, there are only three such activities permitted. The } \\
\text { limitations governing a bank's investment in shares of a non- } \\
\text { financial company, at } 15 \text { percent of equity capital is somewhat } \\
\text { generous; reducing the exposure to one such company relative } \\
\text { to a bank's capital would encourage greater diversity in the } \\
\text { investment portfolio and reduce risk. }\end{array}$ \\
\hline 6. Capital adequacy & $\begin{array}{l}\text { Largely } \\
\text { Compliant }\end{array}$ & $\begin{array}{l}\text { The capital adequacy framework is based on international } \\
\text { standards for standardized approaches to credit, market and } \\
\text { operational risk in Pillar I, with add-ons in some areas (such as } \\
\text { credit concentration risk) and an emphasis on core capital. } \\
\text { Pillar II is a significant component of the capital adequacy, } \\
\text { though the process is somewhat informal. } \\
\text { Banks use the "standardized approach" in determining risk } \\
\text { weights. Thus, risk weights do not vary greatly with economic } \\
\text { conditions. }\end{array}$ \\
\hline $\begin{array}{l}\text { 7. Risk } \\
\text { management } \\
\text { process }\end{array}$ & Compliant & $\begin{array}{l}\text { The regulatory framework is fairly comprehensive, but dense } \\
\text { and complex. BOI is commended for its current efforts towards } \\
\text { a more principles-based rulebook in this area. The upcoming } \\
\text { reform should be the opportunity to further specify the principle } \\
\text { of segregation of functions and to treat settlement risk. }\end{array}$ \\
\hline 8. Credit risk & Compliant & $\begin{array}{l}\text { Based on a large number of detailed directives and supervisory } \\
\text { guidance, credit risk is subject to close and intensive scrutiny. } \\
\text { The BOI is encouraged to move towards a more } \\
\text { comprehensive regulation of this risk, with a view to } \\
\text { incentivizing banks to develop and upgrade their internal } \\
\text { ratings systems. }\end{array}$ \\
\hline $\begin{array}{l}\text { 9. Problem assets, } \\
\text { provisions, and } \\
\text { reserves }\end{array}$ & Compliant & $\begin{array}{l}\text { Rules on problem assets, provisioning, and reserves are fully } \\
\text { adequate. Further harmonization of the rules relating to assets } \\
\text { classification and provisioning is under way. However, the } \\
\text { accounting definition of impaired debts does not allow one to } \\
\text { identify separately the debts to borrowers that are unlikely to } \\
\text { repay, regardless of any collateral recollection. }\end{array}$ \\
\hline $\begin{array}{l}\text { 10. Large exposure } \\
\text { limits }\end{array}$ & Compliant & $\begin{array}{l}\text { Based on comprehensive regulation, BSD makes sure that } \\
\text { management correctly defines, measures, monitors, and } \\
\text { controls large credit exposures or concentrations of other kinds } \\
\text { (by sectoral, by geographic area, by collateral and by product). } \\
\text { This oversight could helpfully be enhanced, at least in the Pillar } \\
\text { Il context, by paying more attention to the correlation of risks. }\end{array}$ \\
\hline $\begin{array}{l}\text { 11. Exposure to } \\
\text { related parties }\end{array}$ & Compliant & $\begin{array}{l}\text { The definition of related parties is strictly delineated, but does } \\
\text { not leave much discretion to the Supervisor. }\end{array}$ \\
\hline $\begin{array}{l}\text { 12. Country and } \\
\text { transfer risks }\end{array}$ & Compliant & BOI exerts fairly proactive oversight of these risks. \\
\hline
\end{tabular}




\begin{tabular}{|c|c|c|}
\hline Core Principle & Grading & Comments \\
\hline 13. Mark & $\begin{array}{l}\text { Materially } \\
\text { non } \\
\text { compliant }\end{array}$ & $\begin{array}{l}\text { For capital purposes, only standardized methods are allowed, } \\
\text { whereas for risk management purposes, value at Risk (VaR) } \\
\text { models-based and stress test methodologies are widespread. } \\
\text { Yet, BOI has not committed sufficient resources to challenge } \\
\text { the adequacy of banks' trading book eligibility policies, the } \\
\text { reliability of their data information systems, valuation } \\
\text { methodologies and internal models. It is strongly recommended } \\
\text { to get the independent capacity to do so. } \\
\text { Furthermore, the assessment of banks' exposure to market } \\
\text { risks is biased by the amalgamation thereof with exposure to } \\
\text { interest-rate risk in the banking book. }\end{array}$ \\
\hline 14. L & $\begin{array}{l}\text { Largely } \\
\text { compliant }\end{array}$ & $\begin{array}{l}\text { BOI performs intensive and on-going oversight of banks' } \\
\text { exposure to liquidity risk. However, this oversight is based on } \\
\text { information that is calculated on a solo basis only. Regulatory } \\
\text { limits apply only to overall liquidity, without breakdown by major } \\
\text { currencies, and only over a one-month horizon. BOI devotes } \\
\text { relatively few resources to on-site examination of the reliability } \\
\text { of information systems and models that banks use for } \\
\text { measuring liquidity risk. }\end{array}$ \\
\hline 15. Ope & $\begin{array}{l}\text { Largely } \\
\text { compliant }\end{array}$ & $\begin{array}{l}\text { The rules are scattered across a large number of directives, } \\
\text { which fail to provide a comprehensive view of the relevant } \\
\text { principles for assessing, monitoring and managing the } \\
\text { operational risk, and even result in some loopholes. } \\
\text { The compulsory reporting requirements currently focus on } \\
\text { events; do not include the related material losses. Relatively } \\
\text { few resources are allocated to on-site examination of this risk. }\end{array}$ \\
\hline $\begin{array}{l}\text { 16. Interest-rate } \\
\text { risk in the banking } \\
\text { book }\end{array}$ & $\begin{array}{c}\text { Non } \\
\text { compliant }\end{array}$ & $\begin{array}{l}\text { There are no specific regulatory provisions regarding the } \\
\text { interest-rate risk in the banking book, except that banks have to } \\
\text { measure it internally and to disclose it. BOI does not receive } \\
\text { any specific reporting on this risk. Rather, it performs an } \\
\text { assessment of a bank's exposure to interest-rate risk that } \\
\text { arises from its whole balance sheet, i.e. including its trading } \\
\text { book exposures. }\end{array}$ \\
\hline $\begin{array}{l}\text { 17. Internal control } \\
\text { and audit }\end{array}$ & $\begin{array}{l}\text { Largely } \\
\text { compliant }\end{array}$ & $\begin{array}{l}\text { The legal and regulatory framework is characterized by a } \\
\text { piecemeal approach to the regulation of internal control and } \\
\text { audit function, which does not ensure full consistency. Hence } \\
\text { BOl's initiative to make the rulebook comprehensive is highly } \\
\text { commended. Some gaps will need to be filled; in particular the } \\
\text { scope of compliance function will need to be expanded. }\end{array}$ \\
\hline
\end{tabular}




\begin{tabular}{|c|c|c|}
\hline Core Principle & Grading & Comments \\
\hline $\begin{array}{l}\text { 18. Abuse of } \\
\text { financial services }\end{array}$ & $\begin{array}{l}\text { Largely } \\
\text { Compliant }\end{array}$ & $\begin{array}{l}\text { Needed amendments to the legal framework are expected to } \\
\text { be passed shortly. } \\
\text { BOl's supervisory practice seems well-suited and has given } \\
\text { rise to sanctions due to breaches of the Law. However, } \\
\text { sanctioning breaches of BOl's directives has not yet been } \\
\text { demonstrated. } \\
\text { The intensity and depth of the information-sharing with foreign } \\
\text { supervisory authorities have not yet been tested. } \\
\text { Anti-money laundering/combating the financing of terrorism } \\
\text { (AML/CFT) provisions and practice are generally of a high } \\
\text { standard. A new regulation to complete and harmonize the } \\
\text { regulatory framework was in the process of being issued at the } \\
\text { time of the assessment. }\end{array}$ \\
\hline $\begin{array}{l}\text { 19. Supervisory } \\
\text { approach }\end{array}$ & Compliant & $\begin{array}{l}\text { BOI has implemented a risk-based approach to supervision, } \\
\text { which is evolving as the supervisors gain experience with it. A } \\
\text { critical component to its success is to make the process more } \\
\text { efficient so that it can be more pro-active and fully effective, an } \\
\text { issue well recognized by the authorities. }\end{array}$ \\
\hline $\begin{array}{l}\text { 20. Supervisory } \\
\text { techniques }\end{array}$ & Compliant & $\begin{array}{l}\text { There is a mix of on-site and off-site supervision, with an } \\
\text { extensive level of communication and cooperation between the } \\
\text { two groups. In that regard, the process is fully integrated. The } \\
\text { risk assessment products, both on-site and off-site are of high } \\
\text { caliber but are in some cases duplicative and need further } \\
\text { streamlining. }\end{array}$ \\
\hline $\begin{array}{l}\text { 21. Supervisory } \\
\text { reporting }\end{array}$ & Compliant & $\begin{array}{l}\text { There is an extensive array of reporting requirements for banks } \\
\text { that provides a wide range of data and risk management } \\
\text { information, both on a consolidated and unconsolidated basis. } \\
\text { Appropriately, the information is used in the supervision } \\
\text { process to evaluate risk and for other objectives. }\end{array}$ \\
\hline $\begin{array}{l}\text { 22. Accounting and } \\
\text { disclosure }\end{array}$ & Compliant & $\begin{array}{l}\text { Disclosure requirements are very strict, and external auditors } \\
\text { are employed to ensure that disclosure rules are adhered to. } \\
\text { Accounting standards require a combination of U.S. GAAP and } \\
\text { IFRS accounting standards. The preponderance of assets, } \\
\text { known as core assets, which are principally earning assets, is } \\
\text { accounted for under U.S. GAAP. The authorities are planning } \\
\text { to transition the banking system solely to IFRS standards by } \\
2013 \text { or later. }\end{array}$ \\
\hline $\begin{array}{l}\text { 23. Corrective and } \\
\text { remedial powers of } \\
\text { supervisors }\end{array}$ & $\begin{array}{l}\text { Largely } \\
\text { Compliant }\end{array}$ & $\begin{array}{l}\text { Remedial powers could be made more flexible relative to the } \\
\text { supervisory toolkit available for early intervention. At present } \\
\text { there is a restrictive list of available remedies in the law, such } \\
\text { as eliminating dividends, but the Supervisor should be able to } \\
\text { apply remedial measures that reflect the level and severity of } \\
\text { the deficiencies. Expansion of powers and strategies } \\
\text { concerning the resolution of a problem bank is under } \\
\text { consideration, which would enable BOI to have the time and } \\
\text { the power to develop more creative approaches to resolving a } \\
\text { bank than exists in the law at present. }\end{array}$ \\
\hline
\end{tabular}




\begin{tabular}{|l|l|l|}
\hline \multicolumn{1}{|c|}{ Core Principle } & Grading & \multicolumn{1}{c|}{ Comments } \\
\hline $\begin{array}{l}\text { 24. Consolidated } \\
\text { supervision }\end{array}$ & $\begin{array}{l}\text { Largely } \\
\text { Compliant } \\
\text { consolidated supervision. Nonetheless, there is a gap in the } \\
\text { supervision of certain securities activities engaged in by } \\
\text { banking corporations. The underwriting activities ostensibly are } \\
\text { under the supervision of the ISA, and an agreement needs to } \\
\text { be worked out on the approach to supervising these entities } \\
\text { more closely (notwithstanding their relatively low level of } \\
\text { activity). Also, closer scrutiny of intercompany and affiliated } \\
\text { company transactions would be valuable. }\end{array}$ \\
\hline $\begin{array}{l}\text { 25. Home-host } \\
\text { relationships }\end{array}$ & $\begin{array}{l}\text { BOl engages in host-home country relationships } \\
\text { commensurate with the size and complexity of the operations of } \\
\text { Israeli banks operating abroad. Formal written agreements } \\
\text { governing cooperation and information exchange are in effect } \\
\text { between BOI and the supervisors who host the preponderance } \\
\text { of Israeli bank activities, although the agreement with one of } \\
\text { the supervisors needs to be expanded to make it more } \\
\text { comprehensive. Foreign bank operations in Israel are at a } \\
\text { relatively low level, and home-host relations are more ad hoc in } \\
\text { nature, reflecting the size and materiality of these banking } \\
\text { operations. }\end{array}$ \\
\hline $\begin{array}{l}\text { Aggregate: Compliant (C) - 18, Largely compliant (LC) - 11, Materially noncompliant (MNC) - 1, } \\
\text { Noncompliant (NC) - 1, Not applicable (N/A) - 0 }\end{array}$ \\
\hline
\end{tabular}

\section{Recommended action plan and authorities' response}

\section{Recommended action plan}

37. Table 2 summarizes the recommendations formulated in the course of the assessment. Note that some recommendations are included under core principles that are rated as fully compliant.

\section{Table 2. Israel: Recommended Action Plan to Improve Compliance with the Basel Core Principles}

\begin{tabular}{|l|l|}
\hline Reference Principle & \multicolumn{1}{|c|}{ Recommended Action } \\
\hline $\begin{array}{l}\text { 1. Objectives, autonomy, } \\
\text { powers and resources }\end{array}$ & $\begin{array}{l}\text { The regulatory framework for risk management policies and } \\
\text { practices lend themselves to a generally more principles-based } \\
\text { approach rather than a rules-based approach. A somewhat more } \\
\text { principles-based approach in the directives that provide } \\
\text { guidance to the banking industry should be considered. }\end{array}$ \\
\hline $\begin{array}{l}\text { 1 (1). Responsibilities and } \\
\text { objectives }\end{array}$ & $\begin{array}{l}\text { A formalized periodic review of banking law and regulation would } \\
\text { ensure that the body of legislation and rulings remains up to } \\
\text { date. A reorganization of laws and directives into a } \\
\text { comprehensive banking law in connection with a review of the } \\
\text { body of legislation and directives should be considered. }\end{array}$ \\
\hline
\end{tabular}




\begin{tabular}{|c|c|}
\hline Reference Principle & Recommended Action \\
\hline $\begin{array}{l}1(2) . \text { Independence, } \\
\text { accountability and } \\
\text { transparency }\end{array}$ & $\begin{array}{l}\text { The influence of the MOF over BOl's salary scale presents some } \\
\text { challenges in recruiting and retaining staff. To counter the } \\
\text { ramifications of this issue, some new strategies will have to be } \\
\text { adopted. For example, the development of a comprehensive in- } \\
\text { house training program, programmed rotation of staff across the } \\
\text { BOI, seconding of staff to banking supervision agencies } \\
\text { overseas, cash bonuses, and the hiring of retired bankers at an } \\
\text { entry- or mid-level position. }\end{array}$ \\
\hline 2. Permissible activities & $\begin{array}{l}\text { A provision should be added to Section } 10 \text { of the Bank Licensing } \\
\text { Law that would enable BOI to approve the introduction of new } \\
\text { banking activities in which the industry may engage. Under } \\
\text { current practice, BOI must interpret the laws very broadly to } \\
\text { accommodate new activities in the market. }\end{array}$ \\
\hline 3. Licensing criteria & $\begin{array}{l}\text { At present, terms defining the control of a banking organization } \\
\text { are contained in a policy, and as a matter of best practice, such } \\
\text { issues typically are contained in laws or regulations. } \\
\text { A directive should be considered that would require a bank to } \\
\text { inform the Supervisor of Banks of a material fact that would } \\
\text { compromise the suitability of a controlling owner of a bank. }\end{array}$ \\
\hline $\begin{array}{l}\text { 4ransfer of Significant } \\
\text { Ownership }\end{array}$ & $\begin{array}{l}\text { Reducing the permissible investment in a non-financial } \\
\text { investment to } 5 \text { percent of a bank's capital should be considered, } \\
\text { to encourage further diversification and reduce risk. } \\
\text { The acquisition of non-bank financial companies located in Israel } \\
\text { should be subject to more formal criteria similar to those } \\
\text { established for the investment in a financial company located in } \\
\text { a foreign jurisdiction. }\end{array}$ \\
\hline 5. Major acquisitions & $\begin{array}{l}\text { More BSD resources should be dedicated to the independent } \\
\text { checking of properness of capital adequacy reporting. } \\
\text { The supervisory review and evaluation process (SREP) should } \\
\text { be strengthened to make it more forward-looking and } \\
\text { prescriptive, and ensure more timely response from banks, } \\
\text { especially when Internal Capital Adequacy Assessment Process } \\
\text { (ICAAP) is judged insufficiently prudent. } \\
\text { The Supervisor should be empowered to require the controlling } \\
\text { shareholders to increase banks' capital. }\end{array}$ \\
\hline 6. Capital adequacy & $\begin{array}{l}\text { The regulatory framework should be streamlined (move from a } \\
\text { piecemeal approach to a comprehensive one). }\end{array}$ \\
\hline $\begin{array}{l}\text { 7. Risk management } \\
\text { process }\end{array}$ & $\begin{array}{l}\text { Regulation concerning credit risk management should be } \\
\text { updated in the near term, with a view to making it more } \\
\text { comprehensive. } \\
\text { This opportunity should be taken to incorporate guidelines for } \\
\text { sound internal rating practices in order to upgrade the banks' } \\
\text { credit risk management practices, to strengthen BSD oversight of } \\
\text { credit risk and forward-looking capacity and, in the longer term, } \\
\text { pave the way for an implementation of advanced approaches for } \\
\text { capital purposes as well. }\end{array}$ \\
\hline
\end{tabular}




\begin{tabular}{|c|c|c|}
\hline & Reference Principle & Recommended Action \\
\hline & Credit risk & $\begin{array}{l}\text { The consistency of applicable rules should be ensured (Directive } \\
314 \text { and new Reporting to Public directives). } \\
\\
\text { The Supervisor should consider requiring banks to submit } \\
\text { information that will clearly single out the assessment of a } \\
\text { borrower's ability to repay from that of collateral collection. }\end{array}$ \\
\hline & $\begin{array}{l}\text { Problem assets, } \\
\text { provisions, and reserves }\end{array}$ & $\begin{array}{l}\text { The oversight of concentration risk should be enhanced by } \\
\text { assessing more systematically the potential concentration risk } \\
\text { that may arise from distinct but correlated exposures. } \\
\text { Banks should be incentivized to devote more attention to } \\
\text { concentration of risk factors, beyond single-name concentration, } \\
\text { and incorporate such analysis in the context of ICAAP/SREP } \\
\text { processes. }\end{array}$ \\
\hline & Large exposure limits & $\begin{array}{l}\text { BSD's powers should be extended in respect of exposures to } \\
\text { related parties by providing the Supervisor more discretion to } \\
\text { apply the definition of such parties, deduct from a bank's capital } \\
\text { such exposures, or require collateralization of them. }\end{array}$ \\
\hline & $\begin{array}{l}\text { Exposure to related } \\
\text { parties }\end{array}$ & $\begin{array}{l}\text { The resources devoted to market risk in on-site examination } \\
\text { should be increased in order to enhance the independent } \\
\text { assessment of the reliability of data processing, the adequacy of } \\
\text { the models' design and implementation, and the prudence of } \\
\text { valuation methodologies. } \\
\text { The off-site assessment of bank's exposure to market risks } \\
\text { should be disentangled from that of interest-rate risk in the } \\
\text { banking book, whether in the framework of the Risk-Based } \\
\text { Supervision (risk cards) or that of the SREP. }\end{array}$ \\
\hline & Country and transfer risks & $\begin{array}{l}\text { Current oversight is based on information that is calculated on a } \\
\text { solo basis only. The regulatory limits only apply to overall } \\
\text { liquidity, and could usefully be extended to breakdown by major } \\
\text { currencies, and with a longer time horizon. } \\
\text { The adequacy of this oversight is very conditional on the reliability } \\
\text { of reported information, which depends itself of banks data } \\
\text { processing and assumption-driven internal models. More } \\
\text { resources should be devoted to checking the quality of this } \\
\text { reported information that not only supports BSD's own oversight } \\
\text { but also is said to drive the bank's management of liquidity risk. }\end{array}$ \\
\hline & Market risks & $\begin{array}{l}\text { The regulatory framework on the basis of a Basel II-compliant } \\
\text { definition of operational risk should be streamlined. } \\
\text { This opportunity should be taken to draw more attention of banks } \\
\text { and BSD to all sources of operational risk, since current oversight } \\
\text { seems too much focused on operational risk relating to } \\
\text { information technology (IT) and/or internal control over financial } \\
\text { reporting. }\end{array}$ \\
\hline & Liquidity risk & $\begin{array}{l}\text { A specific regulation should be introduced regarding the } \\
\text { treatment of interest-rate risk in the banking book } \\
\text { The assessment of this risk should be disentangled from that of } \\
\text { market risk in the SREP framework (consider interest-rate risk in } \\
\text { the banking book on a stand-alone basis). }\end{array}$ \\
\hline
\end{tabular}




\begin{tabular}{|c|c|}
\hline Reference Principle & Recommended Action \\
\hline 15. Operational risk & $\begin{array}{l}\text { The legal and regulatory framework related to internal control and } \\
\text { audit could usefully be streamlined. } \\
\text { The opportunity of the upcoming revision of this regulatory } \\
\text { framework could be taken to fill the gaps in respect of: } \\
\text { - the organizational structure (segregation of critical functions, } \\
\text { such as business origination, payments and settlements, } \\
\text { reconciliation) } \\
\text { - the scope of the compliance function } \\
\text { - the ability of a bank's internal audit to access any outsourced } \\
\text { functions. }\end{array}$ \\
\hline $\begin{array}{l}\text { 16. Interest-rate risk in the } \\
\text { banking book }\end{array}$ & $\begin{array}{l}\text { The adequacy of policies and processes that banks have put in } \\
\text { place to meet high ethical and professional standards and } \\
\text { prevent them from being used for criminal activities should be } \\
\text { ensured on a consolidated basis. } \\
\text { The new AML/CFT regulation should be adopted and } \\
\text { implemented. }\end{array}$ \\
\hline 17. Internal control and audit & $\begin{array}{l}\text { Increased efficiency could be sought in the application of the } \\
\text { risk-based supervision program. Elimination of duplicative } \\
\text { processes and methods could be considered to streamline the } \\
\text { risk-based products that are produced. }\end{array}$ \\
\hline $\begin{array}{l}\text { 18. Abuse of financial } \\
\text { services }\end{array}$ & $\begin{array}{l}\text { While the supervisory process can be made more efficient, there } \\
\text { is a need to expand the staff so that full implementation of risk- } \\
\text { based supervision can be effected. Added staff also would } \\
\text { facilitate implementation of Basel II and other important } \\
\text { initiatives that have been undertaken. }\end{array}$ \\
\hline 19. Supervisory approach & $\begin{array}{l}\text { With the full conversion to IFRS under consideration, the } \\
\text { authorities should obtain plans and monitor the progress of the } \\
\text { banks during the conversion period to ensure that they will be } \\
\text { ready for the conversion on the designated date. }\end{array}$ \\
\hline 20. Supervisory techniques & $\begin{array}{l}\text { The rotation of external auditing firms has been under } \\
\text { consideration, but has not been acted upon. Such a requirement } \\
\text { could have the benefit of creating some competition in the } \\
\text { industry, as there are a minimal number of firms providing these } \\
\text { services at present. }\end{array}$ \\
\hline
\end{tabular}




\begin{tabular}{|c|c|}
\hline Reference Principle & Recommended Action \\
\hline 21. Supervisory reporting & $\begin{array}{l}\text { The powers granted with respect to supervisory actions under } \\
\text { Section } 8 \mathrm{C} \text { of the Ordinance are explicit and prescriptive with } \\
\text { respect to the application of supervisory actions. The provision } \\
\text { should be amended to enable the Supervisor of Banks to apply } \\
\text { supervisory actions commensurate with the deficiencies in the } \\
\text { bank. } \\
\text { While the Supervisor may take remedial actions against a bank's } \\
\text { affiliated companies, and there are various protections in the law } \\
\text { against abusive practices, there is no explicit power to ring-fence } \\
\text { a bank. A regulation that governs relations with affiliates and the } \\
\text { nature and type of intercompany transactions as well should be } \\
\text { considered. } \\
\text { The authority granted under Section } 8 D \text { of the Ordinance needs } \\
\text { to be expanded and strengthened to afford the Supervisor of } \\
\text { Banks with the flexibility to apply an appropriate strategy in the } \\
\text { event intervention in a problem bank is warranted. }\end{array}$ \\
\hline $\begin{array}{l}\text { 22. Accounting and } \\
\text { disclosure }\end{array}$ & $\begin{array}{l}\text { A more detailed and operational agreement should be reached } \\
\text { with the ISA on the supervisory approach to the securities- } \\
\text { related activities housed in nonbank subsidiaries (such as asset } \\
\text { management and underwriting). }\end{array}$ \\
\hline $\begin{array}{l}\text { 23. Corrective and remedial } \\
\text { powers of supervisors }\end{array}$ & $\begin{array}{l}\text { The regulatory framework for risk management policies and } \\
\text { practices lend themselves to a generally more principles-based } \\
\text { approach rather than a rules-based approach. A somewhat more } \\
\text { principles-based approach in the directives that provide } \\
\text { guidance to the banking industry should be considered. }\end{array}$ \\
\hline 24. Consolidated supervision & $\begin{array}{l}\text { A formalized periodic review of banking law and regulation would } \\
\text { ensure that the body of legislation and rulings remains up to } \\
\text { date. A reorganization of laws and directives into a } \\
\text { comprehensive banking law in connection with a review of the } \\
\text { body of legislation and directives should be considered. }\end{array}$ \\
\hline
\end{tabular}

\section{Authorities' response to the assessment}

38. The Israeli authorities want to express their appreciation to the IMF and the assessment team for their comprehensive work. The FSAP has been a useful exercise. The worldwide experience of the IMF and the use of a common methodology have delivered a useful insight into the current state of banking regulation and supervision of the banking sector in Israel.

\section{The authorities welcome the overall assessment that indicates a high level of} observance of the BCP in Israel. Notwithstanding this good result, the developments in the global financial sector, in general, and in the Israeli financial and banking sectors, in particular, continue to call for supervisory actions. The recommendations of the IMF are therefore well received and will be considered carefully by the authorities in their continuous efforts for strengthening supervision.

40. Generally, the authorities share the views expressed in the assessments of the BCP. With regard to market risk (CP 13) and interest-rate risk in the banking book (CP 16), the authorities acknowledge the gaps between Israeli regulatory practices in these 
risk areas and the Basel methodology and accept the recommendations. However, the authorities believe that their practices are effective and commensurate with the low volumes and the characteristic of the activity in the trading books of Israeli banks. It should be emphasized that the BSD covers interest-rate risk, though the coverage does not necessarily differentiate between the banking book and the trading book. The authorities will devote more supervisory attention to market risk and to interest-rate risk through the on-site process, and will issue a regulation specifically concerning interest-rate risk in the banking book.

\section{Furthermore there are a number of recommendations and comments where the authorities would like to respond as follows:}

- $\quad$ CP 1, regarding principle-based approach or rule-based approach; the authorities seek to reach a right balance between these approaches. Experience shows that the principle-based approach is not right in some areas as it leaves too much discretion to the banks. The authorities adopt the principle-based approach in all areas that are suitable to this approach.

- $\quad \mathrm{CP} 5$, regarding investment limitation in non-financial companies; the authorities will consider the recommendation to set a lower regulatory limit on the investment in one such company.

- $\quad$ CP 6, regarding capital adequacy; while authorities agree with the recommendations, they would like to respond that the Supervisor of Banks announced that he will adopt Basel III; even before the formal adoption, BSD required that hybrid instrument should already comply with Basel III. The work on Basel 2.5 is in process. Until now, BSD has preferred not to issue a formal request to a bank to strengthen its capital base following supervisory review of bank's internal assessment. However, following this supervisory review, BSD conducted a dialogue with some banks which resulted in strengthening the capital adequacy of those banks. The authorities feel comfortable from the capital adequacy perspective with the implementation of the standardized approach in pillar I calculation complemented by a rigorous implementation of risk sensitive forward-looking pillar II calculation. In addition, BSD encourages banks to continue their progress in implementing Basel II standards for internal rating systems.

- CPs 10, 11, 23, and 24, regarding intra-group transaction and related parties; the Supervisor is empowered to regulate such transactions. Furthermore, the current regulation and supervision covers these issues adequately, considering other limitations on banking groups' structure and ownership. Nevertheless, the authorities will consider strengthening the regulation in this area including relevant ring-fencing arrangements.

- $\quad$ CP 14, regarding liquidity risk; updating regulation will soon be issued and will refer to the issues raised in the assessment, although most of these issues are already covered by BSD's supervisory practices. In particular, BSD currently 
examines through the on-site process the quality of the data used by banks for their internal models, and checks their logic through off-site process. Moreover, BSD will devote more resources to the validation of reported data in the liquidity as well as in other areas.

- $\quad$ CP 15, regarding operational risk; shortly after the mission a new regulation concerning operational risk management was issued, implementing the recommendation to streamline the regulatory framework. However, even after issuing the new regulation, other regulations continue to include elements of operational risk due to the nature of these risks, and so will Basel's paper on this issue, as it refers to Basel's other documents. BSD covers various operational risk aspects through off-site and on-site processes. Moreover, staff from the designated operational risk on-site unit will strengthen its participation in other on-site units' examinations in order to cover operational risk aspects of these examinations.

- $\quad$ CP 23, regarding corrective and remedial powers of the Supervisor; the authorities share the assessors' recommendations and comments. The Supervisor operates under very old legislation that clearly needs to be updated to the best practice standards. BSD is in the process of preparing proposals to amend a legal framework for bank resolution, giving the BOI flexible resolution tools in dealing with banks that have reached a level of significant deterioration but are still solvent.

- $\quad$ CP 24, regarding consolidated supervision; the authorities accept the comments related to securities activities (those performed by asset management and underwriting subsidiaries). BSD will map the existing gaps and will act to close them in cooperation with the Israeli Security Authority.

\section{Detailed ASSESSMent}

\section{Table 3. Israel: Detailed Assessment of Compliance with the Basel Core Principles}

\begin{tabular}{|l|l|}
\hline Principle 1. & $\begin{array}{l}\text { Objectives, autonomy, powers, and resources. An effective system of banking } \\
\text { supervision will have clear responsibilities and objectives for each authority involved in } \\
\text { the supervision of banks. Each such authority should possess operational } \\
\text { independence, transparent processes, sound governance and adequate resources, } \\
\text { and be accountable for the discharge of its duties. A suitable legal framework for } \\
\text { banking supervision is also necessary, including provisions relating to authorization of } \\
\text { banking establishments and their ongoing supervision; powers to address compliance } \\
\text { with laws as well as safety and soundness concerns; and legal protection for } \\
\text { supervisors. Arrangements for sharing information between supervisors and } \\
\text { protecting the confidentiality of such information should be in place. }\end{array}$ \\
\hline Description & $\begin{array}{l}\text { BOI has clear responsibility for bank supervision under two specific laws: the Bank of } \\
\text { Israel Law, 5770 - 2010, and the Banking Ordinance, 1941. These laws explicitly } \\
\text { empower BOI to be the bank supervisor, with authority over commercial banks and } \\
\text { other specialized institutions regarded as banking corporations under the law. The } \\
\text { Ordinance empowers BOI with the power to carry out most supervisory functions. }\end{array}$ \\
\hline
\end{tabular}


Under the Ordinance, $\mathrm{BOI}$ is empowered to carry out all banking supervision activities, including on-site and off-site supervision, effecting corrective measures when appropriate, collecting financial and supervisory information through prudential returns, managing problem bank situations, and sanctioning banks for unsafe and unsound banking practices A third law, the Banking (Licensing) Law, 5741 - 1981, authorizes $\mathrm{BO}$ to license banks and revoke such licenses when appropriate, identifies permissible activities and governs the transfer of significant ownership and major acquisitions.

The legal framework provides supervisory tools that would require banking corporations to comply with laws and directives relating to safety and soundness issues. The tools range from routine measures requiring that corrective measures be taken to resolve deficiencies to the suspension or removal of officers and directors and the revocation of a banking license.

Under the law, $\mathrm{BO}$ is autonomous, but its independence is compromised by the authority of the Ministry of Finance to influence the salary scale of $\mathrm{BO}$ employees. Such influence ultimately could have an adverse effect on the ability of BOI to attract or retain sufficient qualified staff in banking supervision, and may inhibit the ability of the banking supervision function to achieve it mission and perform its responsibilities in a satisfactory manner. At present, the number of staff in the Banking Supervision Department may be already insufficient to carry out all of its bank supervision responsibilities.

An Advisory Committee, with membership including representatives from the banking industry, the ISA, the MOF, business and academia serves the Governor and the Supervisor of Banks in a consultative capacity. A Licensing Committee, drawn from the membership of the Advisory Committee but excluding bank representatives, serves in a similar role for licensing issues. There is otherwise no apparent influence from other governmental agencies in the conduct of BOl's routine supervisory responsibilities, nor do other agencies appear to influence BOl's decision making process relating to supervisory issues. Funding for bank supervisory activities is derived from the central bank budgetary process.

The legal framework indemnifies bank supervisors against damages resulting from the discharge of their responsibilities, and provides protection against the costs of defending acts of commission or omission in the discharge of their duties in good faith. Such indemnification has been upheld in the Israeli court system

The Ordinance mandates confidentiality of information obtained by $\mathrm{BOI}$ while carrying out its responsibilities, and provides exceptions in case of criminal proceedings or when authorized by the bank in question. There are exceptions for the exchange of information between Israeli authorities engaged in the supervision of the financial system, and for supervisory authorities overseas. Supervisory information may be sent to these authorities when such authorities need the information in carrying out their supervisory responsibilities, and there is certainty that the information will be treated in a confidential manner. BOI has established written protocols with two foreign bank supervisors to facilitate the sharing of information for supervisory purposes. In other cases, cooperative arrangements and the exchange of information are conducted on an informal basis.

\begin{tabular}{|l|l|}
\hline Assessment & Compliant \\
\hline Comments & $\begin{array}{l}\text { BOI has a comprehensive set of laws and directives governing the supervision of } \\
\text { banking corporations. The legal framework is principally rule-based, and possesses a } \\
\text { great deal of prescriptive detail. However, the emphasis on risk management policies }\end{array}$ \\
\hline
\end{tabular}


and practices and the introduction of risk-based supervision are principals-based processes. The authorities should consider a more principles-based approach in the directives relative to providing guidance to the banking industry on various policies and processes regarding risk management.

While the laws that establish $\mathrm{BO}$ as the supervisor of banks are reasonably comprehensive, there are areas of the law that should be strengthened to provide $\mathrm{BOI}$ with greater flexibility and to strengthen some aspects of the law, notably the provisions of Section $8 \mathrm{~A}$ and $8 \mathrm{C}$ of the Ordinance on powers in the event of a problem bank situation, and the directive governing relationships between affiliated entities in a banking corporation.

Principle 1(1). Responsibilities and objectives. An effective system of banking supervision will have clear responsibilities and objectives for each authority involved in the supervision of banks.

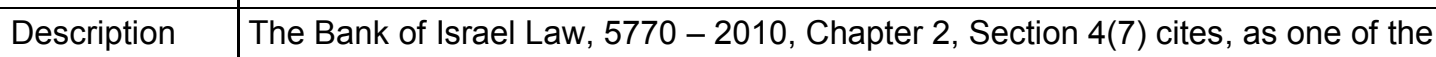
functions of the $\mathrm{BOI}$, the supervision and regulation of the banking system. The Banking Ordinance, 1941, establishes the supervisory framework with which banks must comply. It empowers the Governor of BOI to appoint a supervisor of banks, who is charged with the responsibility of, inter alia, examining banking corporations, establishing directives regulating the conduct of banking business in a safe and sound manner, imposing remedial actions, requiring the submission of prudential returns and resolving financially impaired banking institutions. The Banking (Licensing) Law, 5741 - 1981 defines the licensing powers of the Governor and the Supervisor of Banks, which include the granting of operating licenses to banking corporations such as, banks, mortgage banks and foreign banks. Additional legislation empowers the bank supervisor in specific activities, or imposes requirements on banks that are enforced by the bank supervisor, including prohibitions against money laundering and terrorism financing.

The objectives of the banking supervisory process are not explicitly stated in the law, but can be inferred from the purposes of directives issued under Section 5(c1) (the Proper Conduct of Banking Business Directives (PCBB Directives) adopted by the $\mathrm{BOI}$ to impose prudential and other requirements) and the bases for supervisory actions stated in Sections $8 \mathrm{~A}$ and $8 \mathrm{C}$ of the Banking Ordinance. PCBB directives are adopted to ensure sound management of a bank, the safeguarding of its customers' interests, and to avert impairment to its ability to meet its liabilities. Furthermore, the BOl's objective to "support the stability and orderly activity of the financial system" is stated in the BOI Law.

$\mathrm{BOI}$ is the sole supervisor of the banking system. However, the powers of authorities supervising other financial institutions and other components of the financial system may directly or indirectly affect the activities of the banking system. These institutions include the ISA, which regulates the securities market and the Ministry of Finance, which regulates insurance companies.

Section 5(c) 1 establishes the power of the bank supervisor to issue prudential standards that banks must meet. The standards are issued as Proper Conduct of Banking Business Directives and address a broad spectrum of safety and soundness and best practice issues, including risk management, the duties and responsibilities of boards of directors, the role and responsibilities of the external auditor, treatment of problem assets, and credit relationships with related parties and large exposures. Additional directives are under development or review for various banking risks, including operational risk and credit risk.

Banking laws and regulations, which are published in the form of directives, are revised or updated as necessary, but there is no formal review process. BOI may provide recommendations for amendments or revisions to existing laws. Such changes in law are subject to Parliamentary approval by the Knesset, but not for 


\begin{tabular}{|c|c|}
\hline & $\begin{array}{l}\text { changes to regulations. All new banking legislation and changes to existing banking } \\
\text { laws are subject to a public consultation process prior to enactment, after which they } \\
\text { are published. The introduction of new banking regulations in the form of directives } \\
\text { also are subject to public consultation. To react to an immediate need to issue a } \\
\text { directive or to inform the banking industry of important issues, the banking Supervisor } \\
\text { issues a supervisory letter. The supervisory letters, which address prudential issues, } \\
\text { are subject to the same approval procedures as directives. They are ancillary to and } \\
\text { supplement the directives. } \\
\text { Through an annual survey that is available to the public on BOl's website, BSD } \\
\text { provides detailed information on developments in the banking industry and on } \\
\text { supervisory and regulatory developments. Aggregate data on the banking system also } \\
\text { is presented on the website, with a link from the BOI website directly to each bank's } \\
\text { complete annual and quarterly financial information. Directive 309, "Controls and } \\
\text { Procedures Relating to Disclosure and Internal Control over Financial Reporting," } \\
\text { requires each banking corporation to publish "clear, exact and timely" information that } \\
\text { enables an accurate assessment of the banking corporation's financial condition. } \\
\text { Disclosure requirements are based on United States requirements related to the } \\
\text { enactment of the Sarbanes-Oxley Act. } \\
\text { With the introduction of a program of risk-based supervision, BOI is better able to } \\
\text { determine and prioritize risks for each banking institution, using financial information } \\
\text { derived from prudential returns and publicly available information in financial } \\
\text { statements as one source of information. A supervisory strategy, which takes the form } \\
\text { of a work plan, reflects the risk profile of the institution and influences the supervisory } \\
\text { attention and resource allocation for the individual banking corporation. }\end{array}$ \\
\hline Asses & Largely Compliant \\
\hline Comments & $\begin{array}{l}\text { Banking laws have not always been amended as promptly as would be desirable. For } \\
\text { example, laws have to be interpreted broadly to allow banks to engage in certain new } \\
\text { activities 9see CP2). } \\
\text { Decades of amendments have led to a somewhat confusing set of provisions. Several } \\
\text { laws have been subject to a number of amendments, such that issues related to a } \\
\text { particular activity or risk area may be found piecemeal in various laws and directives. } \\
\text { In particular, the Banking Ordinance, 1941, has been subject to a number of } \\
\text { amendments, and a number of sections or provisions of the law have been repealed. } \\
\text { There has not been a comprehensive review of the law since it was enacted. To } \\
\text { supplement the existing law, a series of directives addressing such issues as specific } \\
\text { risk areas, corporate governance and bank activities have been developed. The } \\
\text { Banking (Licensing) Law has some similar characteristics. To rectify this, the } \\
\text { authorities may wish to consider undertaking a comprehensive review of the laws and } \\
\text { directives pertaining to banking, which would be subject to periodic review. As part of } \\
\text { the review, directives related to risk management and corporate governance can be } \\
\text { established as part of the banking law, thereby closing a gap in the Ordinance. } \\
\text { Certain rules are more appropriately contained in the banking law. One such ruling, } \\
\text { which is communicated in the form of a directive, is the restriction on related party } \\
\text { lending. A provision in the law expressly addressing this issue should be developed. }\end{array}$ \\
\hline \begin{tabular}{|l|} 
Principle 1(2). \\
\end{tabular} & $\begin{array}{l}\text { Independence, accountability and transparency. Each such authority should } \\
\text { possess operational independence, transparent processes, sound governance and } \\
\text { adequate resources, and be accountable for the discharge of its duties. }\end{array}$ \\
\hline Description & $\begin{array}{l}\text { In law, BOI is an independent, autonomous organization. Section } 5 \text { of the Bank of } \\
\text { Israel Law, } 5770 \text { - } 2010 \text { states that to attain its objectives and discharge its function, } \\
\text { "the bank shall be autonomous in choosing its action and exercising its powers." The } \\
\text { Supervisor of Banks is appointed by the Governor of BOI, and in accordance with the } \\
\text { provisions of Section } 5 \text { of the Banking Ordinance, 1941, has a range of powers to } \\
\text { supervise banks. }\end{array}$ \\
\hline
\end{tabular}


There is no evidence of government or industry influence on routine supervisory decisions. There are a number of events under the law in which the Supervisor must gain the approval of the Governor prior to taking action. However, the Supervisor has, as a sounding board, an Advisory Committee, which acts on a consultative basis, on certain issues such as new directives, and a Licensing Committee for consultation on licensing matters. The Governor appoints the members of the Committee. A representative of the Ministry of Finance is a member of the Committee enabling him to provide some measure of influence over policy matters. The Chairman of the ISA also serves on the Committee, together with representatives from the private sector.

There are other events that precipitate involvement in the supervisory process by the Ministry of Finance. For example, while the Governor may determine a new permissible business activity for the banking industry, as a matter of practice the Ministry of Finance is consulted in connection with approval of the activity.

The Supervisor of Banks prepares an annual working plan based on at least a three year revolving plan, which states the objectives outlined for banking supervision. The plan, together with the annual budget for banking supervision, is presented to the senior management of BOI for approval. Semi-annually, the Supervisor of Banks reports to the Governor and BOI senior management on the execution of the work plan.

The Supervisor of Banks' operations are financed from the budget of $\mathrm{BOI}$, which is subject to parliamentary review annually.

In general the Supervisor of Banks has been able to attract and retain staff with the requisite skills to supervise the banking industry. There are some gaps, the most acute of which is a paucity of talent addressing quantitative modeling and issues related to Basel II, and the evaluation of market and interest-rate risk. The supervisory staff is well educated and the management cadre and mid-level staff possess a high degree of experience.

Since 1985, supervision of wages and accompanying benefits of BOl's employees, like those of other employees of the public sector, is the responsibility of the Minister of Finance. This has remained the situation under the new Bank of Israel Law enacted in 2010. However, BOI has been granted the right to appeal the decisions of the Minister of Finance to the Prime Minister. The new Law also determines that in making decisions regarding wages of BOl's employees, the Minister of Finance and the Prime Minister shall take into consideration the needs of the $\mathrm{BO}$ and its labor decisions.

In December 2007, a new collective wage agreement for BOl's employees was signed, with the approval of the Director of Wages at, the Ministry of Finance. Under the terms of the new agreement, the salary and accompanying benefits of the then existing BOl's employees (known as "first generation") were somewhat reduced and those of newly-hired employees (known as "second generation") were reduced, in most components, to equalize those of Government employees. This hinders the recruitment of new prospective employees, and precipitates an increase in turnover. There is a concern that, over time, the overall quality and skill levels of BOl's staff, including that of the banking supervision staff, will deteriorate, as BOI is finding it difficult not only to compete with the private sector, but also with the public sector. There may already be a shortage of qualified staff in banking supervision, which has impeded the full implementation of risk-based supervision and the Basel II and Basel III Accords.

The Governor is appointed for a five-year term by law, but the term of service for the Supervisor of Banks is not set in the law, nor is the circumstances under which the 


\begin{tabular}{|c|c|}
\hline & $\begin{array}{l}\text { Supervisor may be terminated. In practice, the Supervisor usually serves a four-year } \\
\text { term. Termination of the Supervisor would be subject to judicial review. }\end{array}$ \\
\hline Assessment & Largely Compliant \\
\hline Comments & $\begin{array}{l}\text { The influence of the Ministry of Finance over BOl's salary scale compromises the } \\
\text { independence of BOI, which may have to be creative in combating the ramifications of } \\
\text { the revised salary scale. Among other possibilities, BOI should consider the } \\
\text { development of a comprehensive in-house training program, rotation of staff to } \\
\text { different units in banking supervision, secondment of staff to banking supervisory } \\
\text { agencies overseas, cash bonuses, and the hiring of retired bankers at an entry- or } \\
\text { mid-level position. Such individuals typically would bring a wealth of experience, } \\
\text { knowledge and maturity to BOI, and are not ordinarily seeking a second career path. } \\
\text { Attrition has become a larger problem, although not yet a critical one. The Public } \\
\text { Service (Restriction after Retirement) Law, 5729-1969, which applies to BOI } \\
\text { employees, requires a one-year cooling off period for banking supervisors and other } \\
\text { employees. Where the provisions of this law do not apply, the Supervisor of Banks } \\
\text { requires from its employees, prior to moving to their new positions, if the candidates } \\
\text { are moving to the banking industry, a cooling-off period that ranges from three months } \\
\text { to one year, depending on the candidate's position in BSD. One possibility would to } \\
\text { require the cooling-off period to be one full supervision cycle. } \\
\text { The role of the Advisory Committee, although it has no decision-making authority, may } \\
\text { be influential in the decisions of the Supervisor of Banks in view of its composition. }\end{array}$ \\
\hline Principle 1(3). & $\begin{array}{l}\text { Legal framework. A suitable legal framework for banking supervision is also } \\
\text { necessary, including provisions relating to authorization of banking establishments } \\
\text { and their ongoing supervision. }\end{array}$ \\
\hline Des & $\begin{array}{l}\text { The Governor is empowered under Section } 4 \text { of the Banking (License) Law } 5741 \text { - } \\
1981 \text { to grant or revoke a banking license. The Supervisor is empowered, under } \\
\text { Section 5(c1) of the Banking Ordinance, 1941, to set prudential standards. The } \\
\text { standards are established in a series of directives addressing safety and soundness } \\
\text { issues and the conduct of bank directors, officers and employees. The directives } \\
\text { require consultation with the Advisory Committee and approval of the Governor prior } \\
\text { to their issuance to the public, including the banking industry, and have the force of } \\
\text { secondary law, as they are in effect, regulations. Additional provisions in Sections } 5 \\
\text { and } 8 \text { A-8D of the Banking Ordinance, } 1941 \text { enable the Supervisor of Banks to engage } \\
\text { in the supervision of the banking system by conducting examinations, collecting } \\
\text { prudential returns and imposing remedial action when warranted. Supervisory letters } \\
\text { complement the legal framework and address issues related to risks and activities } \\
\text { such as capital adequacy, corporate governance and risk management. These are } \\
\text { principally operational letters that complement the directives, but occasionally their } \\
\text { content may have instructions that will be converted to a directive at such time as the } \\
\text { directive is developed. } \\
\text { The Licensing Law also establishes a set of criteria that must be evaluated in } \\
\text { connection with granting of a license (Section } 6 \text { ), and also establishes minimum } \\
\text { capital requirements for a de novo operation (Section 7). Circumstances under which } \\
\text { a banking license may be revoked also are set in the Law (Section } 8 \text { ). } \\
\text { As a matter of practice, while not required in the law, BOI holds consultations with the } \\
\text { banking industry prior to the issuance of directives, providing a forum for the banking } \\
\text { industry to respond to proposed safety and soundness regulations. Such consultations } \\
\text { are also held with the Association of CPAs. [supervisory letters which deal with } \\
\text { material issues are subject to a similar consultation and approval process as are } \\
\text { directives]. }\end{array}$ \\
\hline Assessment & Compliant \\
\hline Comm & 51 \\
\hline
\end{tabular}




\begin{tabular}{|c|c|}
\hline & $\begin{array}{l}\text { necessarily provide the flexibility in all cases where it may be needed. Laws } \\
\text { addressing permissible activities and remedial actions are two such examples (CP } 2 \\
\text { and CP 23). There are also some gaps in the law. For example, while there are some } \\
\text { regulations addressing the nature and level of transactions between the entities } \\
\text { belonging to a banking corporation, there is no comprehensive law that addresses the } \\
\text { issue in its entirety, including relations with affiliated companies. }\end{array}$ \\
\hline Principle 1(4). & $\begin{array}{l}\text { Legal powers. A suitable legal framework for banking supervision is also necessary, } \\
\text { including powers to address compliance with laws as well as safety and soundness } \\
\text { concerns. }\end{array}$ \\
\hline Description & 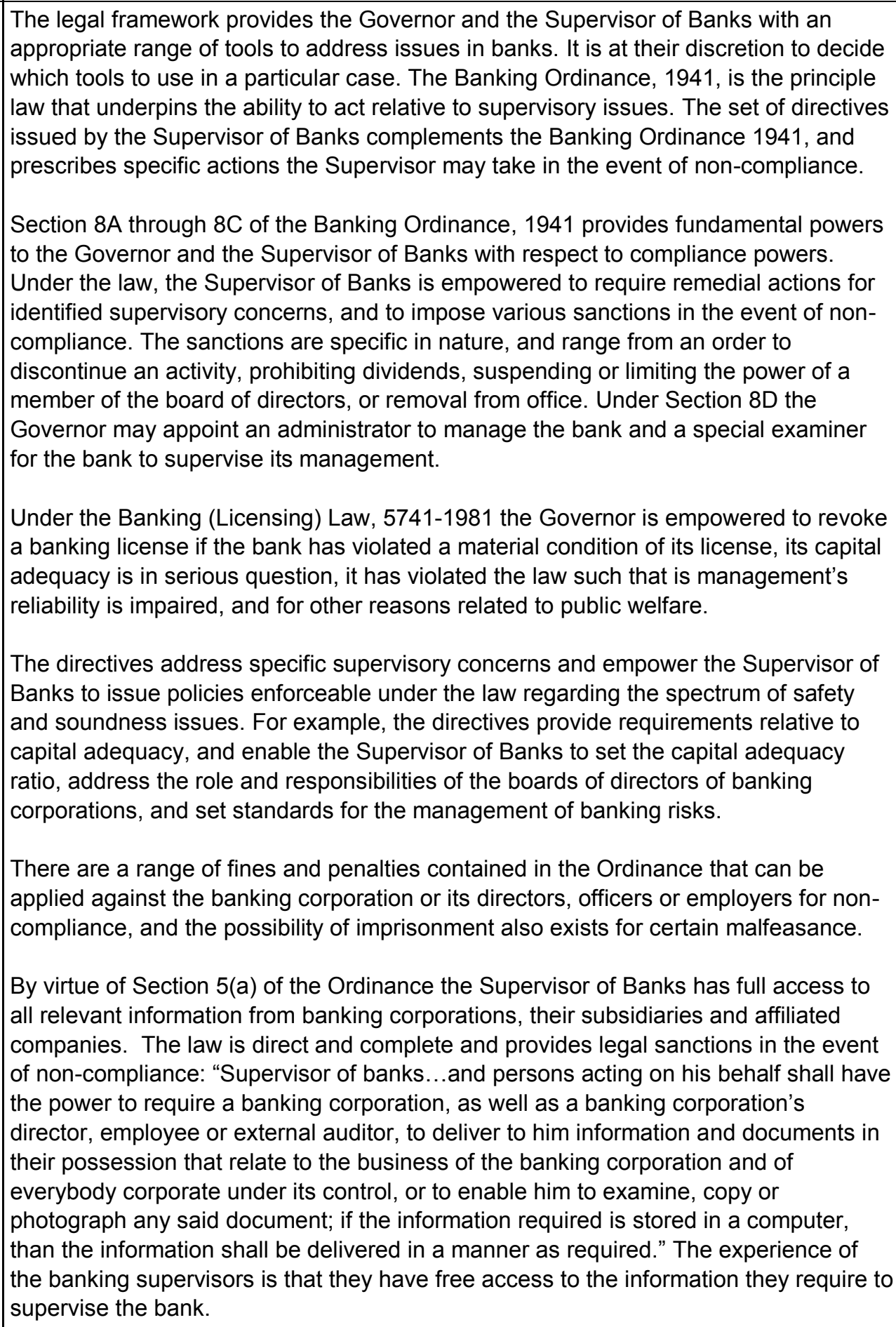 \\
\hline Assessment & Compliant \\
\hline Comments & Most laws and directives empower the Supervisor of Banks to apply discretion relative \\
\hline
\end{tabular}




\begin{tabular}{|c|c|}
\hline & $\begin{array}{l}\text { to the application of enforcement powers. Nevertheless, enforcement powers could be } \\
\text { enhanced by strengthening the provisions of Sections } 8 \mathrm{~A} \text { and } 8 \mathrm{C} \text { of the Ordinance } \\
\text { such that } \mathrm{BOI} \text { would have greater flexibility and more powers in the event of a problem } \\
\text { bank situation. (For example, Section } 8 \mathrm{~A} \text { could be enhanced by clarifying that the } \\
\text { section authorizes actions based on any violation of law or regulations and that the } \\
\mathrm{BOI} \text { may require affirmative remedial actions). Moreover, a ring-fencing mechanism } \\
\text { should be considered as a corrective measure in the event certain types of abusive } \\
\text { practices by affiliates of banking corporations occur. In practice, the more stringent } \\
\text { enforcement powers that are available to the authorities at present are rarely invoked. } \\
\text { Most such cases are handled on an informal basis and resolved satisfactorily in that } \\
\text { manner. }\end{array}$ \\
\hline Principle 1(5). & $\begin{array}{l}\text { Legal protection. A suitable legal framework for banking supervision is also } \\
\text { necessary, including legal protection for supervisors. }\end{array}$ \\
\hline Description & $\begin{array}{l}\text { Section 7A (a) of the Damages Ordinance provides that no liability shall attach to } \\
\text { public servants in their discharge of public duties. The Ordinance applies to both acts } \\
\text { of commission or omission in connection with the discharge of their duties, unless } \\
\text { such actions were taken knowingly with the intent of causing damage. }\end{array}$ \\
\hline Assessment & Compliant \\
\hline Comments & $\begin{array}{l}\text { This provision in the Ordinance has been tested in the judicial system and upheld by } \\
\text { the courts. }\end{array}$ \\
\hline Principle 1(6). & $\begin{array}{l}\text { Cooperation. Arrangements for sharing information between supervisors and } \\
\text { protecting the confidentiality of such information should be in place. }\end{array}$ \\
\hline ion & $\begin{array}{l}\text { BOI has arrangements, both formal and informal, with other Israeli supervisory } \\
\text { agencies to facilitate cooperation and the exchange of information. In } 2007 \text {, a } \\
\text { Memorandum of Understanding was executed to regulate the manner in which } \\
\text { cooperation, information sharing and coordination of enforcement actions would be } \\
\text { regulated. The signatories to the Memorandum are the Supervisor of Banks, the } \\
\text { Commissioner of the Capital Market, Insurance, and Savings Authority in the Ministry } \\
\text { of Finance, and the ISA. } \\
\text { Beginning in 2011, the three supervisors formed a Liaison Committee to hold joint } \\
\text { meetings monthly to promote and establish cooperation and information exchange } \\
\text { between the supervisors. The meetings provide a forum to discuss trends and } \\
\text { changes in the sectors they supervise and their implications and proposed legislative } \\
\text { and regulatory issues. To date they have issued a joint policy on a Fit and Proper } \\
\text { regimen for directors and officers of financial institutions, and have begun work on } \\
\text { anti-money laundering issues. } \\
\text { A fourth Israeli agency, the Israeli Antitrust Authority, has joined the monthly meetings, } \\
\text { but is not a signatory to the Memorandum. } \\
\text { Such arrangements exist with the foreign bank supervisors where Israeli operations } \\
\text { overseas or foreign banking activities in Israel are considered material. There is a } \\
\text { formal Memorandum of Understanding with the Federal Reserve and the FDIC in the } \\
\text { United States addressing the exchange of information and cooperative arrangements. } \\
\text { The agreement covers, inter alia, examination results, licensing issues, and } \\
\text { cooperative efforts on anti-money laundering and terrorist financing issues. With the } \\
\text { FSA in the United Kingdom, the Supervisor of Banks has an agreement pertaining to } \\
\text { the exchange of information and a cooperative framework relative to liquidity positions } \\
\text { and liquidity issues. As a result of these arrangements, Bank of Israel receives } \\
\text { supervisory information from the US and UK regulators. } \\
\text { Informal mechanisms exist with other supervisors, with FINMA in Switzerland the most } \\
\text { prominent. Communication and cooperative efforts are maintained through meetings } \\
\text { and formal visits to Switzerland to exchange information and to facilitate cooperative }\end{array}$ \\
\hline
\end{tabular}




\begin{tabular}{|c|c|}
\hline & $\begin{array}{l}\text { arrangements; FINMA sends representative to BOI as well. The results of the } \\
\text { relationship were on exhibit with the recent acquisition of a Swiss bank by a large } \\
\text { Israeli banking corporation. } \\
\text { The power to exchange information with other regulatory authorities is found in } \\
\text { Sections 15A.1 and 15A.2 of the Banking Ordinance, 1941, notwithstanding the } \\
\text { secrecy provisions of Section 15A of the Ordinance. Section 15A stipulates that } \\
\text { information covered under the Ordinance or the Banking (Licensing) Law, } 5741 \text { - } \\
1981 \text {, cannot be divulged or shared unless it is in connection with a criminal } \\
\text { investigation or the banking corporation consents to its disclosure. } \\
\text { Section 15A.1 of the Ordinance provides an exception to a supervisory authority in a } \\
\text { foreign country under two specific circumstances: (a) the information is needed for the } \\
\text { discharge of the foreign authority's responsibilities in the supervision of the banking } \\
\text { institution, and (b) the foreign supervisor confirms that confidentiality requirements } \\
\text { similar to Section } 15 \mathrm{~A} \text { applies to it or it will not forward the information to a third party. } \\
\text { Section } 15 \mathrm{~A} .2 \text { of the Ordinance provides an exception to other supervisory authorities } \\
\text { in Israel, specifically the ISA and the Commissioner of the Capital Markets, Insurance } \\
\text { and Savings at the Ministry of Finance. In accordance with the provision, the } \\
\text { Supervisor of Banks may divulge information to representatives of these authorities if } \\
\text { he is aware that the information is required in the discharge of the authority's } \\
\text { functions. The existing MOU between the three domestic authorities establishes the } \\
\text { framework under which information may be exchanged. }\end{array}$ \\
\hline Assessment & Compliant \\
\hline Comments & $\begin{array}{l}\text { With the exception of the United States and United Kingdom, cooperative } \\
\text { arrangements with other foreign supervisors generally are the same as with } \\
\text { Switzerland, but on a scale commensurate with the operations of banking corporations } \\
\text { in the home or host country venue. }\end{array}$ \\
\hline Principle 2. & $\begin{array}{l}\text { Permissible activities. The permissible activities of institutions that are licensed and } \\
\text { subject to supervision as banks must be clearly defined and the use of the word } \\
\text { "bank" in names should be controlled as far as possible. }\end{array}$ \\
\hline Desc & $\begin{array}{l}\text { The term "bank," or banking corporation as it appears in Israeli law, is defined in the } \\
\text { Banking (Licensing) Law, } 5741-1981 \text {, but it comprises several financial institutions } \\
\text { that are empowered to accept deposits and grant loans (except for a joint service } \\
\text { company).. Section } 1 \text { of the Law defines a banking corporation as a commercial bank, } \\
\text { a foreign bank, a mortgage bank, an investment finance bank, a business promotion } \\
\text { bank, a financial institution or a joint service company. Section } 21 \text { of the Law prohibits } \\
\text { institutions that are not defined as banking corporations from accepting deposits from } \\
30 \text { or more persons and granting credit at the same time. Section } 13 \text { further prohibits } \\
\text { institutions that are neither banks nor foreign banks from accepting and maintaining } \\
\text { demand deposits payable by check. } \\
\text { In practice there are no investment finance banks or business promotion banks } \\
\text { operating at present, and only one financial institution as defined in the law continues } \\
\text { to operate. } \\
\text { The Banking Ordinance, } 1941 \text { restricts the use of the word "bank" to a commercial } \\
\text { bank, a foreign bank, a mortgage bank, an investment finance bank, and a business } \\
\text { promotion bank. The Governor is empowered to force an institution that uses the word } \\
\text { bank but is not licensed as such to discontinue using the term, or to no longer use an } \\
\text { expression as to suggest that it is engaging in a banking business. } \\
\text { The Banking (Licensing) Law, } 5741 \text { - } 1981 \text { explicitly lists the permissible activities of } \\
\text { each type of a bank. Section } 10 \text { applies to commercial banks, and separate sections } \\
\text { identify the activities in which more specialized institutions such as foreign banks, }\end{array}$ \\
\hline
\end{tabular}




\begin{tabular}{|c|c|}
\hline & $\begin{array}{l}\text { mortgage banks and business promotion banks are permitted to engage. The deposit } \\
\text { taking activity of specialized banks, particularly mortgage banks and investment } \\
\text { finance banks, are related specifically to the permissible activities of these institutions } \\
\text { and acceptance of any other kind of deposits must be approved by the Supervisor of } \\
\text { Banks. As a result, these institutions do not have broad deposit gathering powers. } \\
\text { Foreign banks have deposit gathering powers similar to commercial banks. } \\
\text { The permissible activities of joint service companies are restricted to services to banks } \\
\text { or their customers. (Joint service companies comprise an ATM operator and a check } \\
\text { clearing company.) } \\
\text { The BOI website maintains the list of all institutions defined as banking corporations } \\
\text { operating in Israel, with contact information and a link to their websites. }\end{array}$ \\
\hline Assessment & Largely Compliant \\
\hline Comments & $\begin{array}{l}\text { A provision should be added to Section } 10 \text { of the Banking (Licensing) Law, } 5741 \text { - } \\
1981 \text { that would enable the Governor, after consultation with the Supervisor of Banks } \\
\text { and the Advisory Committee, to approve the introduction of new banking activities in } \\
\text { which the industry may engage. Under current practice, BOI must interpret the laws } \\
\text { very broadly to accommodate new activities in the market. } \\
\text { The Law provides BOI with the authority to prevent abuses in the use of the word } \\
\text { "bank", but it needs to be tightened. There is a less than complete prohibition in } \\
\text { accepting deposits by non-banking institutions, and there are some loopholes or } \\
\text { inconsistencies that should be addressed in the law. For example, non-bank } \\
\text { institutions are permitted to accept cash deposits. The Post Office can accept } \\
\text { deposits, and engage in other activities similar to the banking powers granted under } \\
\text { Section 10, and it calls itself a bank, acting under a special law which defines the } \\
\text { activities it may engage in and it is not allowed to issue credit. While Section } 13 \text { of the } \\
\text { Banking (Licensing) Law, } 5741 \text { - } 1981 \text { prohibits the acceptance of demand deposits } \\
\text { by non-bank entities, there is no prohibition on the acceptance of other types of } \\
\text { deposits. Certain institutions defined in the law as banks no longer exist and should be } \\
\text { removed from the legislation. }\end{array}$ \\
\hline Princ & $\begin{array}{l}\text { Licensing criteria. The licensing authority must have the power to set criteria and } \\
\text { reject applications for establishments that do not meet the standards set. The } \\
\text { licensing process, at a minimum, should consist of an assessment of the ownership } \\
\text { structure and governance of the bank and its wider group, including the fitness and } \\
\text { propriety of Board members and senior management, its strategic and operating plan, } \\
\text { internal controls and risk management, and its projected financial condition, including } \\
\text { its capital base. Where the proposed owner or parent organization is a foreign bank, } \\
\text { the prior consent of its home country supervisor should be obtained. }\end{array}$ \\
\hline Des & $\begin{array}{l}\text { The Governor has the power to license banks, and there is no other regulatory agency } \\
\text { in Israel with this authority. The Licensing Committee, comprised of five } \\
\text { representatives from the Advisory Committee, acts as a consultative body to the } \\
\text { Governor on licensing issues. Section } 6 \text { of the Banking (Licensing) Law } 5741 \text { - } 1981 \\
\text { establishes the criteria for the licensing of banks. The criteria include the financial } \\
\text { strength and quality and reasonableness of strategic and business plans of the } \\
\text { applicant, the suitability of prospective officers and directors under a "fit and proper" } \\
\text { regimen, competitive factors and the contribution to the level of service in the banking } \\
\text { system, and the public good. For a foreign bank, there must be reciprocity in the } \\
\text { granting of licenses between Israel and the home country. } \\
\\
\text { The Supervisor of Banks has established a policy and operating procedures that } \\
\text { reflect the criteria contained in the law that are utilized in assessing prospective } \\
\text { licensing applications. In accordance with the policy, supervisors evaluate the } \\
\text { proposed strategic and operating plans of the bank, information regarding risk } \\
\text { management and internal control processes, projections and budgets relative to the }\end{array}$ \\
\hline
\end{tabular}


business plan, and the financial strength of the applicant. In connection with a review of the applicant's financial strength, supervisors assess the capacity of the owners to contribute additional capital, although there is nothing in the law that necessarily sets as a condition for granting the license a requirement for the owners to contribute additional capital.

The Governor, at his discretion may refuse to issue a license if the criteria are not met by the applicant, information provided is inadequate or for other valid reasons. Such decisions are subject to judicial review.

The assessment process for the review of a licensing application includes an investigation and evaluation of ultimate ownership and control of the licensed institution and its management structure on both a solo and consolidated basis. Ultimate owners are considered, as a matter of policy, to be those individuals who own the bank directly or indirectly through other corporate holdings and regardless of the configuration of their equity interest. The ownership structure cannot be changed once the license is granted without prior permission from the Governor.

The ultimate owners of the institution, including all shareholders with an ownership interest of 5 percent or more, are subject to the fit and proper regimen to determine their suitability as owners or holders of means of control. As a result, owners who hold their interest indirectly are also subject to fit and proper considerations. Prospective directors, executive officers and the internal auditor also must undergo the fit and proper test. For directors, their suitability includes knowledge on a broad basis of material banking activities and risks. In accordance with a directive, at least 20 percent of the board must have proven banking experience, and at least 20 percent must have expertise in accounting and finance. If the shares of the institution are widely held and there is no controlling owner ( 20 percent or more, depending on the size of the bank for the purposes of licensing activities), only the officers and directors are subject to the suitability test. The suitability test includes a review of the integrity of the individuals, both personally and in business relationships, experience and education in disciplines relevant to banking, and an investigation of possible conflicts of interest. A criminal background check also is conducted.

Section 7 of the Banking (Licensing) Law 5741 -1981 requires a minimum paid-in capital of NIS 10 million, although in practice the Governor requires US\$150 million at present. This requirement is not codified in the law. The source of the capital contribution is traced and carefully examined to determine ultimate owners. No license will be granted if the Governor is not comfortable with the ownership structure or the ultimate owner cannot be identified.

In the event a foreign bank intends to establish a branch or subsidiary in Israel, the Supervisor of Banks seeks a written confirmation from the home country supervisor that there is no objection to the proposed establishment. The Supervisor of Banks also will seek to verify that the home country supervisor practices consolidated supervision and meets international supervisory standards to a reasonable degree based on the Basel Core Principles. The World Bank and IMF websites are sources used to make this evaluation.

In the event a license was obtained under false pretenses, such as providing false or misleading information, or new information is obtained that would have adversely influenced the granting of the license, there are grounds for revoking it under Section 8(c) of the Banking (Licensing) Law, 5741-1981. Under this Section, the Governor may revoke the license if there has been a breach in its material terms. This power has been used. 


\begin{tabular}{|c|c|}
\hline & $\begin{array}{l}\text { As a matter of practice, newly licensed banking corporations would receive intensive } \\
\text { off-site attention in their formative years, and on-site examinations would be more } \\
\text { frequent. An important aspect of this scrutiny is to determine whether the bank is } \\
\text { meeting strategic goals and projections and is complying with the terms of the license. }\end{array}$ \\
\hline Assessment & Compliant \\
\hline Comments & $\begin{array}{l}\text { The authorities have reconsidered the policy of insisting that a banking corporation } \\
\text { have a controlling owner. As a practical matter, in a small economy, the number of } \\
\text { applicants who could have a controlling interest is comparatively small. There are } \\
\text { disadvantages to having a controlling owner from a safety and soundness perspective } \\
\text { as well. One such problem is that the controlling owners may not provide strength to } \\
\text { the bank, either financially or managerially. In the Israeli experience, there has been } \\
\text { an issue with controlling groups related to the raising of additional capital. To avoid } \\
\text { diluting their ownership interests, they issued Tier II capital instruments to meet capital } \\
\text { requirements rather than equity capital. } \\
\text { The "Marani" legislation addresses the issue of a banking corporation possessing a } \\
\text { widely held ownership. To reduce the possibility that sitting directors or senior } \\
\text { management may be in a position to appoint new directors, there are provisions in the } \\
\text { law that would enable a Committee to nominate new directors. In this connection, the } \\
\text { influence of the government on the appointment of directors under such } \\
\text { circumstances should be minimized. In a proposed amendment, the Committee would } \\
\text { be appointed by the Governor of the BOI, and only the Chairman of this Committee, } \\
\text { who must be a judge emeritus, would be appointed by the Minister of Finance after } \\
\text { consultation with the Chief Justice of the Supreme Court. } \\
\text { In practice, license applications have been limited, but the infrastructure to evaluate } \\
\text { and process applications is in place, including established procedures and criteria to } \\
\text { evaluate proposals. There has not been an application by investors to establish a de } \\
\text { novo bank in many years. The most recent licensing case is the application by a large } \\
\text { Israeli bank to acquire a bank abroad. As a condition for approval, the Governor will } \\
\text { require, inter alia, that the Israeli bank ensure that the risk management and internal } \\
\text { control systems in the foreign bank, including those for anti-money laundering, will be } \\
\text { improved to a level satisfactory to the Supervisor of Banks. A reporting system will be } \\
\text { instituted to inform the Supervisor of progress made in that regard. }\end{array}$ \\
\hline Principle 4. & $\begin{array}{l}\text { Transfer of significant ownership. The Supervisor has the power to review and } \\
\text { reject any proposals to transfer significant ownership or controlling interests held } \\
\text { directly or indirectly in existing banks to other parties. }\end{array}$ \\
\hline Descr & $\begin{array}{l}\text { The Banking (Licensing) Law, } 5741 \text { - } 1981 \text { governs the transfer of significant } \\
\text { ownership, and authorizes the Governor to reject a proposed transfer. The Law } \\
\text { defines significant ownership and controlling interest as "control" and "means of } \\
\text { control." Control is the ability, singly or in conjunction with others, to direct the activity } \\
\text { of a corporation, and sets specific conditions under which control would be construed. } \\
\text { One of four conditions must be met for means of control: (a) voting rights; (b) the } \\
\text { power to appoint a director; (c) the right to receive dividends; and (d) the ability to } \\
\text { assert claims on remaining assets of the bank, if any, when liquidated. } \\
\text { Section } 34 \text { (a) of the Banking (Licensing) Law, } 5741 \text { - } 1981 \text { stipulates that the } \\
\text { acquisition of more than } 5 \text { percent of means of control in a bank or bank holding } \\
\text { company must receive the permit of the Governor prior to the acquisition. } \\
\text { Section } 34 \text { (b) of the Banking (Licensing) Law, } 5741 \text { - } 1981 \text { stipulates that the } \\
\text { acquisition of control in a bank or a bank holding company must receive the permit of } \\
\text { the Governor prior to the acquisition. The Governor must consult with the Licensing } \\
\text { Committee prior to granting approval for the acquisition of more than } 5 \text { percent of } \\
\text { means of control and for transfer of ownership or acquisition of control. The scrutiny } \\
\text { involved in such an acquisition would depend on whether the purchase represented }\end{array}$ \\
\hline
\end{tabular}




\begin{tabular}{|c|c|}
\hline & $\begin{array}{l}\text { an increase in an existing owner's interest in the bank or a new shareholder. } \\
\text { The Governor also has the discretion, under Sections } 34 \text { a and } 35 \text { of the Banking } \\
\text { (Licensing) Law, } 5741 \text { - 1981, to force divestment of the interest if acquired without } \\
\text { prior approval or to revoke the permit of ownership under specified circumstances, } \\
\text { such as submission of false information. Under Section 35, the Governor has the } \\
\text { power to nullify any votes cast by an owner who has not sought approval for an } \\
\text { acquisition and been granted a permit, prohibit the appointment of directors by the } \\
\text { owner of the shares, and to require the divestiture of the ownership interest. } \\
\text { Transfer of ownership proposals may be rejected as well, if the ownership criteria are } \\
\text { not met. As stipulated in Section } 34 \text { (b1), the criteria are similar to the establishment of } \\
\text { a de novo bank, and include an assessment of financial strength, the identification of } \\
\text { the source of funding for the acquisition, undergoing the fit and proper test for the new } \\
\text { owners, and the identification of the ownership structure. } \\
\text { On an annual basis, any person holding more than a } 5 \text { percent interest in a bank } \\
\text { where there is a controlling shareholder, or any person possessing more than } 2.5 \\
\text { percent of a bank where the shares are widely held and there is no controlling } \\
\text { shareholder, must file a report stating the amount of shares held, whether held directly } \\
\text { or indirectly, the ultimate or beneficial owner and the structure of ownership, such as } \\
\text { holdings through a trustee or nominee. The report must be filed as well when there is } \\
\text { a change in the shares held by a controlling owner. } \\
\text { At present, banks are not required to inform the Supervisor of Banks of material } \\
\text { information that could affect the suitability of a controlling shareholder. }\end{array}$ \\
\hline Asses & Compliant \\
\hline Comments & $\begin{array}{l}\text { As a matter of policy, BOI considers a controlling interest of a bank to be } 20 \text { percent or } \\
\text { greater for one of the five large banking groups, and } 50 \text { percent or more for other } \\
\text { banks. The controlling shareholders are defined as the ultimate owners of the bank } \\
\text { irrespective of the complexity of the ownership structure. No other ownership interest } \\
\text { can exceed } 5 \text { percent of the shares in a bank, with the exception of institutional } \\
\text { investors, such as mutual funds and provident funds, who are permitted to hold } 10 \\
\text { percent of the shares. The intent of the policy is to prevent large blocks of shares to } \\
\text { be owned by competing stakeholders in the same banking corporation, which has } \\
\text { been viewed as deleterious to its welfare. The rationale underpinning this philosophy } \\
\text { is that one strong ownership group best serves the bank. } \\
\text { As a matter of best practice, terms defining control of a banking organization normally } \\
\text { are contained in the law rather than communicated as a policy. A law or directive } \\
\text { reflecting the definitions of controlling interests is warranted. Moreover, a directive } \\
\text { should be considered that would require a bank to inform the Supervisor of Banks of a } \\
\text { material fact or condition that would compromise the suitability of a controlling owner } \\
\text { of a bank. }\end{array}$ \\
\hline Princ & $\begin{array}{l}\text { Major acquisitions. The Supervisor has the power to review major acquisitions or } \\
\text { investments by a bank, against prescribed criteria, including the establishment of } \\
\text { cross-border operations, and confirming that corporate affiliations or structures do not } \\
\text { expose the bank to undue risks or hinder effective supervision. }\end{array}$ \\
\hline Description & $\begin{array}{l}\text { Section } 20 \text { (a) } 2 \text { of the Licensing Law permits a bank to acquire another bank, either in } \\
\text { Israel or abroad, subject to certain criteria; Section } 32 \text { lists the criteria for the issuance } \\
\text { of a permit to acquire an interest in a foreign bank (see also BCP } 4 \text { above), These } \\
\text { criteria are designed to ensure that corporate affiliations or structures do not expose } \\
\text { the bank to undue risks or hinder effective supervision. The BSD does in practice } \\
\text { assess whether criteria are met, and also reviews each application for its wider } \\
\text { implications in terms of stability, effective supervision, and other objectives such as } \\
\text { conduct of business. }\end{array}$ \\
\hline
\end{tabular}


The Banking (Licensing) Law, 5741 - 1981, governs the acquisition of non-bank investments by a banking corporation, both financial and non-financial. Section 10 of the Law establishes the list of permissible activities in which banks are allowed to engage. Section 11 specifies the non-bank financial investments that a bank may control or in which it may have an investment. It is a restrictive list; aside from bank service companies, permitted investments include non-bank subsidiaries that engage in a permitted banking business, foreign corporation that, were it to conduct business in Israel, would require a license under the Banking (Licensing) Law, 5741 - 1981, underwriting and asset management activities, and companies engaged in the sale of homeowners insurance while serving in the capacity of an agent.

The Law requires a bank to obtain approval from the Supervisor of Banks prior to acquiring a non-bank financial subsidiary whose activities fall within the permissible activities articulated in Section 10 of the Law, ISA

Underwriting and asset management activities are licensed by the ISA (ISA), but they operate under a permit granted by the Supervisor of Banks. The supervision of these entities is the responsibility of the ISA.

Under Section 11, a bank also may gain a controlling interest in a foreign non-bank financial subsidiary that engages in a Section 10 activity. Directive 306 also addresses investments in such companies located overseas. BOI must be notified at least 45 days prior to the investment, and in connection with the notification the bank must submit a strategic and business plan for the company, information describing the manner in which it will manage and monitor the affairs of the foreign institution, its plan of risk management and internal controls, and the organizational and ownership structure relative to the banking corporation. The financial condition of the parent bank also is assessed in connection with the proposed investment. Management of the entity is not subjected to a suitability test, as the host country supervisor typically performs background investigations. Sources of information for BOl's evaluation of the host country supervisor include data and assessments contained on the websites of the World Bank, the IMF and the OECD.

There are no criteria established formally in the law governing the approval of nonbank financial companies located in Israel that will engage in Article 10 powers, but the approval process follows closely the criteria required of a de novo bank or foreign bank subsidiary. The rationale for differences in treatment between foreign and Israeli non-bank financial institutions is that regulations related to banks cover also these Israeli subsidiaries.

A controlling interest in other types of non-bank financial companies not specified in the Law, in accordance with Section 11 (a) (5), must receive the prior approval of the Supervisor of Banks subject to consultation with the Licensing Committee. These are rare cases. An example is the holding of shares in a non-financial company whose exposure, because of the buy-back of shares by the investee, exceeds the permissible equity interest. Such ownership interests would be permitted for a defined period of time. Insurance companies are not permitted to be acquired by banks.

Investments in non-financial companies do not require the approval of $\mathrm{BOI}$, but aggregate exposure to such companies is limited to 25 percent of the bank's capital. Investments in non-financial companies are permitted such that the exposure equals no more than 15 percent of equity capital for investment in one Israeli corporation. Section $23 \mathrm{~A}$ allows a bank to invest up to 20 percent of its capital in non-financial companies, only if it does not hold more than 5 percent of the means of control in each company and has no right to nominate a director. The remaining 5 percent can be invested in the equity of foreign non-financial companies with virtually no presence in Israel. 


\begin{tabular}{|c|c|}
\hline Comments & $\begin{array}{l}\text { As a matter of prudential supervision, the acquisition of non-bank financial companies } \\
\text { located in Israel should be subject to more formal criteria similar to those established } \\
\text { for the investment in a financial company located in a foreign jurisdiction. } \\
\\
\text { While the overall investment limitation in non-financial companies is reasonable, to } \\
\text { prevent an undue concentration in one investment, the limitation on the investment in } \\
\text { Israeli companies could be further granulated by limiting the investment in one such } \\
\text { company to } 5 \text { percent of capital. }\end{array}$ \\
\hline Principle 6. & $\begin{array}{l}\text { Capital adequacy. Supervisors must set prudent and appropriate minimum capital } \\
\text { adequacy requirements for banks that reflect the risks that the bank undertakes, and } \\
\text { must define the components of capital, bearing in mind its ability to absorb losses. At } \\
\text { least for internationally active banks, these requirements must not be less than those } \\
\text { established in the applicable Basel requirement. }\end{array}$ \\
\hline Description & 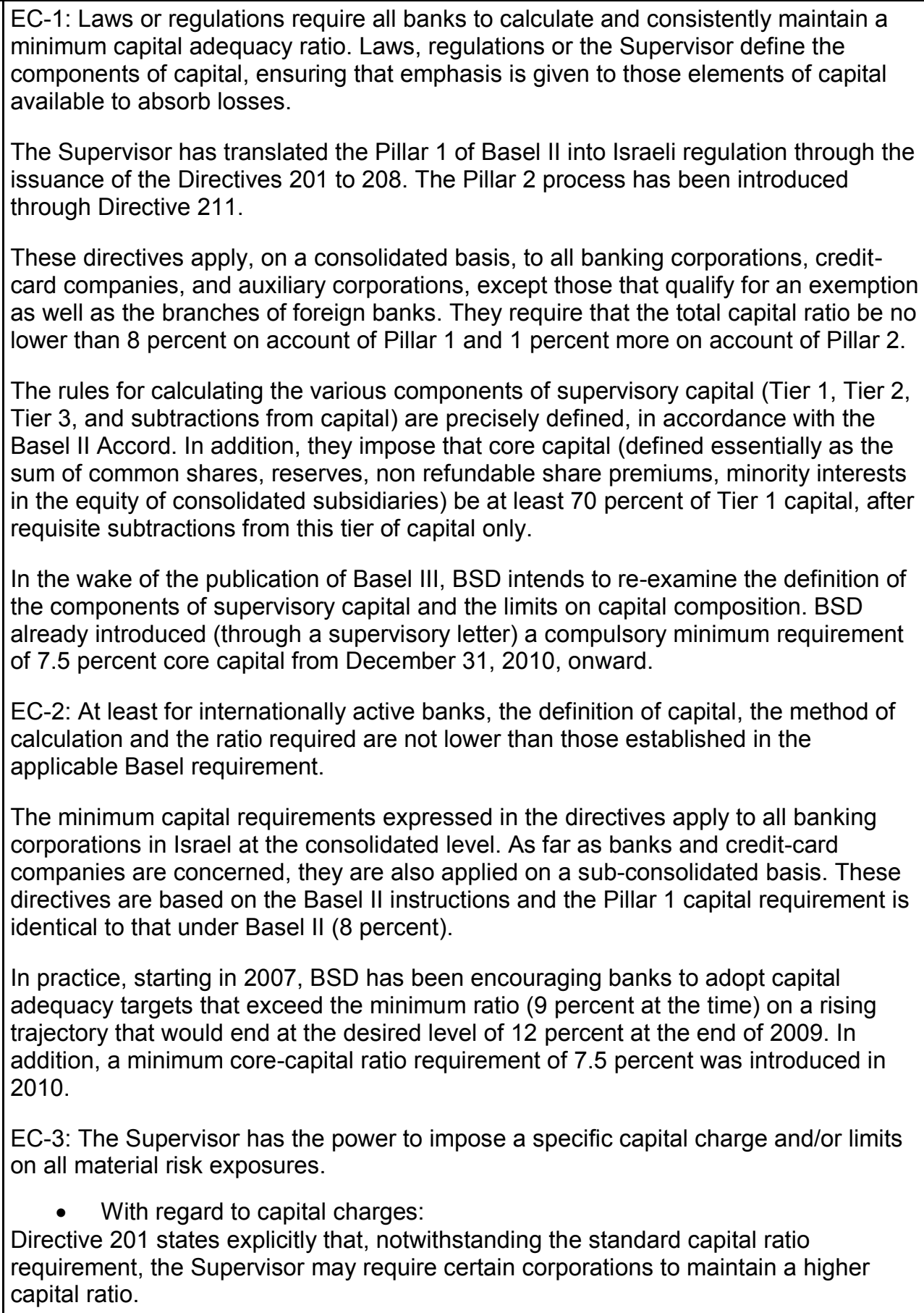 \\
\hline
\end{tabular}


Furthermore, the Supervisor has in the wake of the increase in risk during the global financial crisis published a number of supervisory letters that address specific aspects of credit-risk management, some of which introduce a stricter capital treatment for some risk exposures. Such has been the case for loans extended to a Purchasing group for the construction of ten dwelling units or more (Letter March, 2010) and for (relatively large) housing loans with more than 60 percent LTV and an adjustable-rate portion equal to or greater than 25 percent (Letter October, 2010).

Likewise, as far as the trading book is concerned, the Supervisor is empowered (Directive 211) to impose additional capital requirements for the market risk arising from less well diversified portfolios, and/or portfolios containing less liquid instruments, and/or portfolios with concentrations in relation to market turnover and/or portfolios which contain large numbers of positions that are marked-to-model. Yet no cases have happened so far.

- With regard to limits:

The Supervisor has issued directives that prescribe limits on material exposures, e.g., on borrower and borrower-group indebtedness (Directive 313). Besides, the

Supervisor may also impose limits on material exposures on a specific corporation or in specific areas of activity, even if such limits are not specified in directives (e.g., the prohibition against issuing a housing loan if the adjustable-rate proportion of the loan surpasses 33.3 percent of the total loan, in the Supervisor's letter of May 3, 2011).

EC-4: The required capital ratio reflects the risk profile of individual banks. Both onbalance sheet and off-balance sheet risks are included.

Directives 201-211, concerning capital measurement and adequacy, are based on the Basel II framework - Pillars I and II. The directives relating to Pillar 1 cover credit risk (Directive 203), market risk (Directive 208), and operational risk (Directive 206), and they take both on-balance-sheet and off-balance-sheet activity into account.

Directive 211 also deals with capital adequacy assessment, but with a view to addressing additional risks. This principles-based directive thus includes general capital requirements in support of all risks and guidelines to encourage banking corporations to develop and use enhanced risk-management techniques. In accordance with Basel II, the directive relates to risks that, among others, were included in Pillar 1 but were not fully treated within that framework (e.g. credit concentration risk) and risks not taken into account in Pillar 1 (e.g. interest-rate risk in the banking-book, and business and strategic risk). In June 2010, BSD published a document on the supervisory review process that complements Directive 211 in respect of the adoption of Pillar 2 of Basel II. The document includes the main principles for supervisory review and specific issues that need to be treated as part of the supervisory review process, e.g. interest-rate risk in the banking-book, credit risk (residual risk, credit concentration risk and counterparty credit risk), market risk, and the supervisory review process as it applies to securitization transactions. Directive 211 states that the Supervisor expects banking corporations to operate at capital ratios exceeding the minimum supervisory ratios and may order them to retain capital beyond said minimum.

The evaluation of the adequacy of the capital tailored to an individual bank is a practice that has taken shape over the past two years on the basis of the supervisory review and evaluation process (SREP). This process includes a comprehensive evaluation of the risk profile of each bank that heads a banking group and of independent banks, as a matter of fact the eight largest banks. This process is conducted each year by the off-site examination units.

The evaluation is derived from Risk Based Supervision (RBS) and "risk cards" for main risks. For each of these risks, the evaluation is broken down into the assessment of both inherent risk and risk management quality. Besides, the level and quality of capital as well as the appropriateness of the internal capital adequacy assessment process (ICAAP) are subject to an evaluation. If the capital ratio derived from ICAAP is lower than that obtained via SREP, BSD enters into a dialogue with the bank. But to date, no bank has been asked formally to maintain a capital ratio other than the one 
that it determined.

EC-5: Capital adequacy requirements take into account the conditions under which the banking system operates. Consequently, laws and regulations in a particular jurisdiction may set higher capital adequacy standards than the applicable Basel requirement.

The Supervisor's directives concerning capital measurement and adequacy are based on Basel II. When the latter has been translated into Israeli regulation, a number of options and national discretions have been used in a conservative way (e.g., weighting of claims on domestic securities firms, rejection of 0 percent credit conversion factor for off-balance sheet commitments, conditions for implementing the preferential risk-weighting of claims secured by residential property), in order to take into consideration Israel's statutory and economic particulars.

Further examples of the application of tougher rules relate to the non-recognition of innovative capital instruments issued through an SPV structure in the capital base. Recent developments, notably in the housing market, have led the Supervisor to impose higher capital requirements for some specific credit exposures.

More broadly, the Supervisor requires the bank to comply with a 9 percent minimum capital requirement (see EC1).

EC-6: Laws or regulations clearly give the Supervisor authority to take measures should a bank fall below the minimum capital ratio.

The Banking Ordinance, 1941 provides the Supervisor with a range of tools to deal with a bank that its capital ratio fell (or about to fall) below the regulatory minimum, insofar as such an event could be considered as impairing the bank's ability to meet its obligations or the proper conduct of its business.

As a matter of practice, the Supervisor takes milder and preemptive measures to prevent a bank from reaching the point where its capital adequacy slips under the minimum. This kind of treatment takes place in accordance with Directive 211 which instructs the Supervisor to consider a series of measures if $s /$ he fears that a certain banking corporation is not meeting the requirements implied by the supervisory principles for capital adequacy assessment. These measures may include heightened monitoring of the banking corporation, limiting the distribution of dividends, demanding that the banking corporation formulate and implement an appropriate plan for the recovery of capital adequacy, and ordering the banking corporation to raise additional capital at once. The Supervisor is given the discretion to invoke the tools best suited to the banking corporation's circumstances and activity environment.

EC-7: Where the Supervisor permits banks to use internal assessments of risk as inputs to the calculation of regulatory capital, such assessments must adhere to rigorous qualifying standards and be subject to the approval of the Supervisor. If banks do not continue to meet these qualifying standards on an ongoing basis, the Supervisor may revoke its approval of the internal assessments.

BSD issued guidelines in regard to the advanced approaches to the estimation of credit risk (Directive 204), but the use of this approach entails explicit BSD approval (Directive 203) for which no banking corporation has applied. Where market and operational risks are concerned, BSD has not yet issued guidelines relating to advanced approaches.

The Supervisor has not issued explicit guidelines either, about the methods to be used in calculating Pillar 2 risks

AC-1: For non-internationally active banks, the definition of capital, the method of calculation and the capital required are broadly consistent with the principles of applicable Basel requirements relevant to internationally active banks. 
AC-2: For non-internationally active banks and their holding companies, capital adequacy ratios are calculated and applied in a manner generally consistent with the applicable Basel requirement, as set forth in the footnote to the Principle.

BSD directives relating to capital measurements and adequacy (Pillar 1) apply uniformly to all banking corporations that operate in Israel. There is no distinction between internationally active banks and non-internationally active ones, including in the definition of capital, the computation methods, and the minimum capital requirements.

Yet, one bank has been allowed to deduct only 50 percent of its share holdings in another bank from its core capital, in the context of a divestment plan

AC-3: The Supervisor has the power to require banks to adopt a forward-looking approach to capital management and set capital levels in anticipation of possible events or changes in market conditions that could have an adverse effect.

The Supervisor has the power to set a capital ratio for banks that exceeds the minimum set in the directives at $\mathrm{h} / \mathrm{her}$ discretion.

In the context of their ICAAP, banks are required (Directive 211) to examine their capital adequacy under other macroeconomic and internal conditions and make sure that appropriate capital for the support of activity is on hand. More specifically, these requirements are directed at two main processes, capital planning as part of strategic planning and strict forward-looking stress tests.

As it examines the banks' ICAAP reports, BSD also examines the capital planning. The stress tests should include reference to management's contingency plans for the treatment of capital write-off in extreme situations. The Supervisor has advised banks individually of his expectations regarding the design and implementation of these stress tests, notably that the capital ratio shall not fall below 9 percent after the stress scenarios are applied.

The banks were requested in the SREP letters, to submit by 31.12 .11 , an updated capital plan that will specify a solidified detailed trajectory and modified targets that will take into account the Basel III guidelines and the global developments pertaining to the capital levels and quality.

AC-4: The Supervisor requires adequate distribution of capital within different entities of a banking group according to the allocation of risks.

The Supervisor's directives concerning capital measurement and adequacy apply not only to every banking corporation (excluding foreign branches and joint services companies) on a consolidated basis, but also to Israeli banking corporations that belong to a banking group and auxiliary corporations that are credit-card companies (Directive 201). Those directives also apply to (Israeli) corporations, which are controlled by a banking corporation or a credit card company and (i) involved in underwriting or management of investment portfolios or (ii) are auxiliary corporations, unless those corporations meet the conditions for an exemption. The conditions for an exemption are immateriality, or full and exercisable backing by the controlling bank (indemnification, lack of restrictions on capital and liquidity transfer, and consolidated risk management).

This incidence, coupled with other limits on corporate shareholdings that apply to banks (a prohibition against holding corporations such as insurance companies, institutional entities, and real corporations beyond a predetermined stake) aim to ensure that every main constituent of the banking group (in terms of exposure to risks) holds capital against its own risks and that the bank that heads the group holds capital against the risks of the group at large. BSD does not require calculation of capital adequacy on a solo basis, but on a sub-consolidated one.

As part of the SREP, a policy was adopted that subsidiaries to which the directives in this matter apply, must maintain capital adequacy at the target rate that the parent 


\begin{tabular}{|c|c|}
\hline & $\begin{array}{l}\text { bank set for the entire group (beyond the minimum). Subsidiaries that have an } \\
\text { aberrant risk profile or engage in activity of a different nature than that of the parent } \\
\text { company are examined in a separate SREP and required to present BSD with an } \\
\text { ICAAP report. } \\
\text { AC-5: The Supervisor may require an individual bank or banking group to maintain } \\
\text { capital above the minimum to ensure that individual banks or banking groups are } \\
\text { operating with the appropriate level of capital } \\
\\
\text { The Supervisor has the power to demand an above-minimum capital ratio (see EC-3). } \\
\text { At the system level, it requires a } 9 \text { percent minimum capital requirement (see EC-2). } \\
\text { At the level of individual banks, the Supervisor conveys its expectations in the course } \\
\text { of the dialogue that follows the SREP (see EC-4). However, under the Basel II regime, } \\
\text { there has been no formal demand for specific capital targets }\end{array}$ \\
\hline Assessment & Largely compliant \\
\hline Comments & 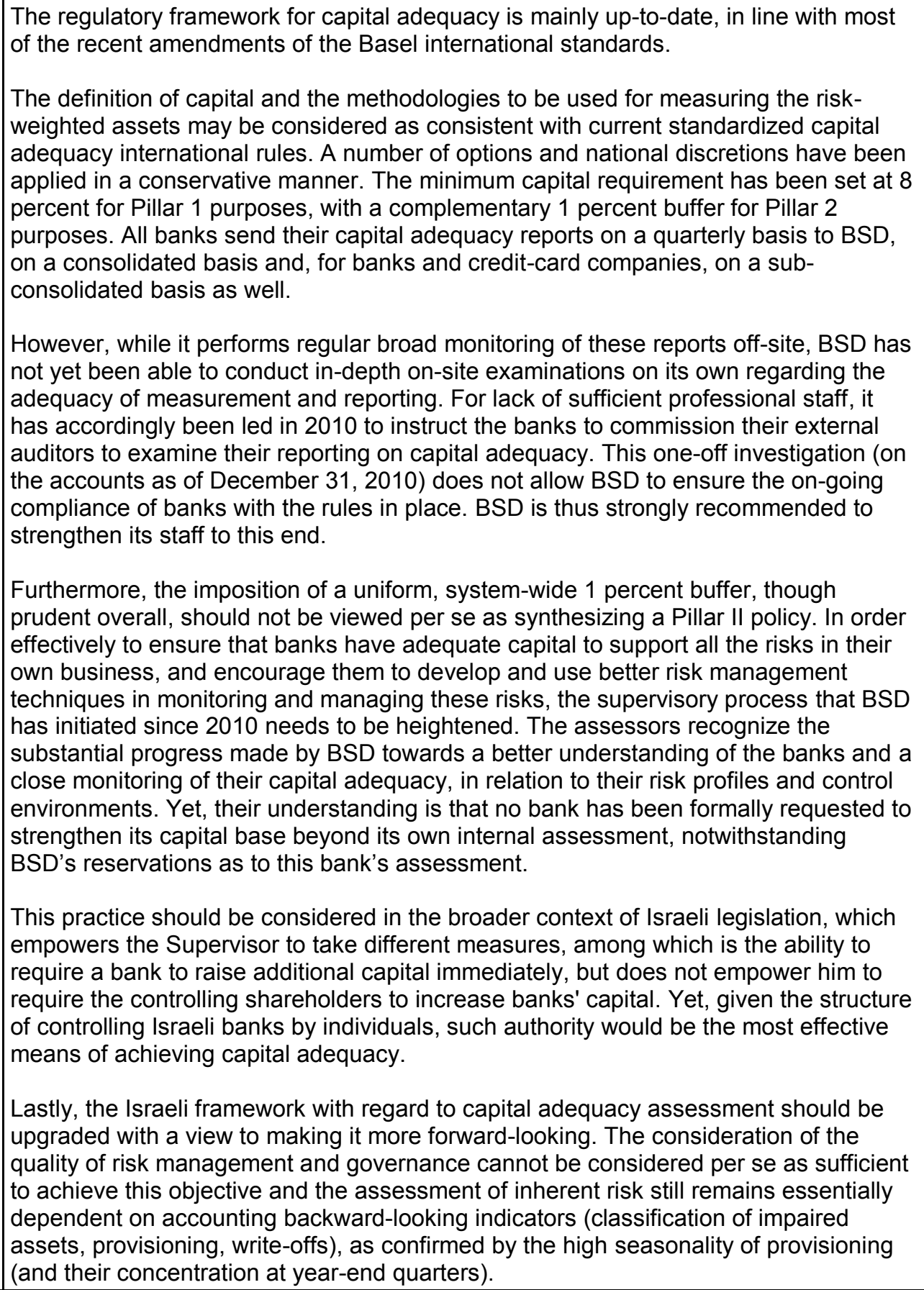 \\
\hline
\end{tabular}


It is worth noting that the regulatory framework does not yet incorporate all of advanced methodologies for measuring risks for capital purposes, neither the amendments relating to Basel 2.5 (applicable by year-end 2011), nor Basel 3 (applicable from 1 January 2013, with transitional and phase-in arrangements).

Principle 7. $\quad$ Risk management process. Supervisors must be satisfied that banks and banking groups have in place a comprehensive risk management process (including Board and senior management oversight) to identify, evaluate, monitor and control or mitigate all material risks and to assess their overall capital adequacy in relation to their risk profile. These processes should be commensurate with the size and complexity of the institution.

Description

EC-1: Individual banks and banking groups are required to have in place comprehensive risk management policies and processes to identify, evaluate, monitor and control or mitigate material risks. The supervisor determines that these processes are adequate for the size and nature of the activities of the bank and banking group and are periodically adjusted in the light of the changing risk profile of the bank or banking group and external market developments. If the supervisor determines that the risk management processes are inadequate, it has the power to require a bank or banking group to strengthen them.

BSD issued several directives that deal with risk-management requirements in a general way, and a large number of directives that address certain aspects of specific risks such as credit, market, liquidity, and operational risk.

The general framework for risk management relies on Directive 301 (for the definition of responsibilities and duties of the board of directors in risk management, the existence of audit and control functions, the channels of reporting and compulsory reporting to management and the board of directors about the bank's exposure to various risks), Directive 339 (for the general requirement for implementation of clear principles and rules for the identification, management, monitoring, and control of risk exposure on a consolidated basis, the approval process in respect of new products and/or activities) and Directive 211 (for the definition of risk management as a vital element in the capital adequacy assessment process).

BSD devotes a lot of work to the assessment of risk-management processes in on-site and off-site examinations. On the one hand, the On-Site Division has teams that specialize in specific risks (credit risk, market and liquidity risks, operational risk and compliance risk), and examine the risk-management processes in their respective risk areas. In addition, a dedicated on-site team for corporate governance reviews various aspects of examination proceedings, including latitudinal processes associated with risk management. On the other hand, the assessment of risk management processes is an important component of off-site ongoing surveillance, in particular in the ICAAPSREP framework. In the context of such assessments, the principle of proportionality is applied, so that the procedures and processes in place are suited to the perceived risk profile of the bank.

EC-2: The supervisor confirms that banks and banking groups have appropriate risk management strategies that have been approved by the board. The supervisor also confirms that the board ensures that policies and processes for risk-taking are developed, appropriate limits are established, and senior management takes the steps necessary to monitor and control all material risks consistent with the approved strategies.

The BSD directives hold the board of directors responsible for approving the overall strategy, including principles for action and risk appetite, and require board approval of overall risk-management policy and of specific risk policies. The board of directors oversees management's actions and is responsible for assuring that the bank has an 
appropriate internal control system.

BSD's directives define management's duties in applying the risk-management policy.

EC-3: The supervisor determines that risk management strategies, policies, processes and limits are properly documented, reviewed and updated, communicated within the bank and banking group, and adhered to in practice. The supervisor determines that exceptions to established policies, processes and limits receive the prompt attention of and authorization by the appropriate level of management and the board where necessary.

The BSD directives specify that the risk-management policy must be worded specifically and should include, among other things, risk-management limits and processes. The board of directors must discuss and approve the corporation's overall risk-management and credit policies at least once a year (directive 301).

The BSD directives specified at EC-1 include a minimum requirement for reporting to management and the board of directors on risk-exposure topics. Thus, it has been determined that the information about a bank's existing exposures to the various market risks, credit risk, and liquidity risk must be presented in a concise manner in the comprehensive "exposures document" (directive 339). This document must be placed before the board of directors and management. It should include a description of the entire set of risks to which the banking corporation is exposed and should present information about the development of the exposures, the officials authorized to manage each exposure and their authorities, data on activities and exposure limits that the board of directors and management have set, etc. Furthermore, management must present the board with monthly reports on the bank's business condition, including the exposures to the various forms of risk (directive 301).

Directive 301 also establishes certain requirements relating to limits' breaches. In regard to credit in particular, it states that the policy must include the definition of authorities for the approval of exceptions. It requires management to report to the board of directors about exceptional transactions and events.

BSD, in both its on-site and off-site examinations, checks for compliance with policy and absence of deviation from the limits established and examines the means that the board of directors and management use to enforce the policies set forth.

EC-4: The supervisor determines that senior management and the board understand the nature and level of risk being taken by the bank and how this risk relates to adequate capital levels. The supervisor also determines that senior management ensures that the risk management policies and processes are appropriate in the light of the bank's risk profile and business plan and that they are implemented effectively. This includes a requirement that senior management regularly reviews and understands the implications (and limitations) of the risk management information that it receives. The same requirement applies to the board in relation to risk management information presented to it in a format suitable for board oversight.

Directives 339 and 301 respectively require that the board of directors and management understand the risks being taken and their implications for the banking corporation. They set forth information requirements allowing the board of directors and senior executives to understand the risk, e.g. requiring concise and clear information in the "exposures document" (see EC3 above) and business reporting. Directive 301 requires the establishment of a board of directors' committee for risk management that shall discuss and recommend to the board policies on the bank's exposure to the various risks and shall oversee the implementation of the policies set. A risk management function must also be established to support management and the 
board in this matter.

Implementation of these requirements is routinely and extensively checked by on-site units, each in its area of expertise (e.g. risk types) and in the course of dedicated examinations that probes the effectiveness of the board of directors' work. This matter is also regularly examined in the off-site proceedings (notably based on the quarterly "exposures documents" that are presented to the board).

EC-5: The supervisor determines that banks have an internal process for assessing their overall capital adequacy in relation to their risk profile, and reviews and evaluates banks' internal capital adequacy assessments and strategies. The nature of the specific methodology used for this assessment will depend on the size, complexity and business strategy of a bank. Non-complex banks may opt for a more qualitative approach to capital planning.

Directive 211 has translated Pillar 2 of Basel II into the Israeli framework.

Accordingly, banks must carry out a comprehensive and detailed Internal Capital Adequacy Assessment Process (ICAAP) and present BSD with annual ICAAP report that summarizes it.

The off-site division is in charge of checking ICAAP reports and of conducting SREP process. The process includes, among other things, filling out "risk cards" (see CP 19), drawing up a comprehensive internal assessment, meetings with the bank, including a meeting between the Supervisor and the board of directors and ends up with an external letter that summarizes the SREP and a letter of response to the ICAAP report.

In practice, the ICAAP reports of the five large banking groups and the three independent banks have been checked in each of the three years since Pillar II was implemented.

EC-6: Where banks and banking groups use models to measure components of risk, the supervisor determines that banks perform periodic and independent validation and testing of the models and systems.

BSD has adopted the standardized approach to the estimation of risks for capital measurement and adequacy purposes. Therefore, banks in Israel do not use internal models for supervisory capital adequacy.

When banks however use models for risk management purposes, BSD requires them to independently validate their risk-measurement models, both at the initial implementation and on a regular basis (directive 339). In the course of its on-site processes, the BSD does not perform a quantitative assessment of these models' adequacy, but focuses on their governance, by examining the function in charge of validating models, the existence of validation procedures, the feasibility of the models and their uses.

EC-7: The supervisor determines that banks and banking groups have adequate information systems for measuring, assessing and reporting on the size, composition and quality of exposures. It is satisfied that these reports are provided on a timely basis to the board or senior management and reflect the bank's risk profile and capital needs.

Directive 339 requires a bank's risk-management system to be based on a computerized management information system that provides comprehensive information about activities, the levels of the risk and the extent to which the activity corresponds to approved policies and exposure limits. 
The Reporting to Public and Reporting to BSD directives require banks to report their risk exposures and capital adequacy on a quarterly basis, accordingly to management and the board of directors. The BSD directives also require the board and management to maintain and check the effectiveness of the internal control of financial reporting and the effectiveness of internal controls and procedures of disclosure of information. The external auditor is asked to express the opinion that the financial statements were drawn up in accordance with BSD's directives.

In the on-site proceedings and off-site processes, the quality of information given to the board of directors is one of the topics examined.

EC-8: The supervisor determines that banks have policies and processes in place to ensure that new products and major risk management initiatives are approved by the board or a specific committee of the board.

Directive 339 requires the board of directors to approve a new activity after it has considered all the risks involved, examined the mechanisms that will be used to manage, measure, and control these risks, and after it has verified that the bank has the personnel, financial resources, and computer infrastructure to assure that the activity will be accommodated and managed appropriately.

The risk-management function must be involved, from the early stages on, in identifying and analyzing risks in a new activity and in extraordinary transactions.

Within the framework of relations with the banking system, it is the banks' practice to keep BSD up-to-date on significant new activities before they take place. In any new activity that requires the Supervisor's approval, before approval is given the BSD makes sure, inter alia, that the activity was approved by the board of directors and also examines the quality of the discussion.

EC-9: The supervisor determines that banks and banking groups have risk evaluation, monitoring, and control or mitigation functions with duties clearly segregated from risktaking functions in the bank, and which report on risk exposures directly to senior management and the board.

BSD requires banks to maintain certain control functions (namely loan review, market risk and liquidity risk control, compliance officer, AML/CFT officer) and also a riskmanagement function headed by a Chief Risk Officer. BSD's directives specify the main duties of these functions, their status in the organization so as to assure their independence and the compulsory reports that they forward to management and/or the board of directors.

The control units usually cover the banking corporation itself; the risk-management function and the CRO cover the banking corporation at the consolidated level.

Supervisory activity in this matter takes place in both off-site and on-site examinations.

EC-10: The supervisor issues standards related to, in particular, credit risk, market risk, liquidity risk, interest rate risk in the banking book, and operational risk.

The Supervisor's directives, guidelines, and publications cover the risks that banking corporations face, focusing on material risks: credit risk, market and liquidity risks, and operational risks (see CP 8 to CP 16). However, no guidelines address directly management of interest rate risk in the banking book.

In his directives on capital measurement and adequacy, the Supervisor requires a 
capital charge against Pillar 1 risks. Directive 211 (relating to Pillar 2) also includes qualitative requirements relating to comprehensive risk assessment and the requirement of an appropriate capital charge in support of all risks inherent to the bank's business.

BSD examines banks' compliance with supervisory requirements in both its on-site and its off-site proceedings.

AC-1: The supervisor requires larger and more complex banks to have a dedicated unit(s) responsible for risk evaluation, monitoring, and control or mitigation for material risk areas. The supervisor confirms that this unit (these units) is (are) subject to periodic review by the internal audit function.

BSD's requirements in regard to control and management functions are specified at EC-9. As a rule, the requirements apply to all banking corporations (and, where relevant, to credit-card companies). However, BSD gives small banks some leeway in implementing the requirements. For example, the risk-control unit is compulsory only to a banking corporation that has activity exposed to market risks that are not negligible.

Directive 339 states that the risk-management and risk-control functions should be subject to auditing by an internal-audit function.

AC-2: The supervisor requires banks to conduct rigorous, forward-looking stress testing that identifies possible events or changes in market conditions that could adversely impact the bank.

Directive 211 set forth a general requirement that banks should conduct periodic reviews of their risk management processes, including stress testing and analysis of assumptions and inputs used for the assessment of their internal capital adequacy assessment. Directive 339 further specifies the need for stress testing or the use of scenario analysis in the specific area of market risk.

Within the ICAAP framework, banking corporations are required to perform vigorous but plausible stress-scenario testing, according to guidance provided by BSD. When it reviews the banks' ICAAP reports, BSD examines the stress scenarios that the banks ran, including their underlying assumptions, the severity of the results, and the actions that each bank intends to take if they materialize.

AC-3: The supervisor requires banks and banking groups to have in place appropriate policies and processes for assessing other material risks not directly addressed in the subsequent $\mathrm{CPs}$, such as reputational and strategic risks.

The BSD directives relating to risk management are said to capture the entire set of risks to which banking corporations are exposed. Thus far, BSD has covered the main risks in specific directives and has not related to reputational risk or strategic risk specifically. However, in regard to the adoption of Pillar 2 of Basel II, directive 211 states explicitly that a capital adequacy assessment should relate to all material risks that the banking corporation faces and that even though "other" risks, such as reputational risk or strategic risk, are not easily measurable, the banking system should continue developing additional techniques for the management of these risks.

When it reviews the ICAAP reports, BSD examines how the bank evaluates the other risks. BSD also evaluates strategic risk and reputational risk (inherent risk and quality of risk management) in the SREP by means of "risk cards" (see CP 19). 


\begin{tabular}{|c|c|}
\hline Comments & $\begin{array}{l}\text { The regulatory framework, though reasonably comprehensive, appears to be dense } \\
\text { and complex insofar as the relevant requirements are scattered across a large } \\
\text { number of rules, enshrined in directives, supervisory letters or circulars. This clearly } \\
\text { raises a challenge in terms of consistency of the regulation, hence of its clarity and } \\
\text { enforceability: yet, the review of supervisory practices in this field seems to confirm } \\
\text { that the quality of risk management in banks is one of the top priorities of BSD and, as } \\
\text { such, is subject to very proactive oversight and monitoring. } \\
\text { In this context, BSD is encouraged to continue in the direction it is now taking, i.e. the } \\
\text { overhaul of its rulebook towards a comprehensive and more principles-based } \\
\text { approach in respect of such a cross-cutting area. This upcoming reform should be the } \\
\text { opportunity further to specify the principle of segregation of functions, not only those in } \\
\text { charge of risk management but also those in charge of monitoring, control and } \\
\text { mitigation functions (e.g. for payments, settlements, reconciliation), from the risk- } \\
\text { taking functions. Also, settlement risk should be allowed for specifically. }\end{array}$ \\
\hline Principle 8. & $\begin{array}{l}\text { Credit risk. Supervisors must be satisfied that banks have a credit risk management } \\
\text { process that takes into account the risk profile of the institution, with prudent policies } \\
\text { and processes to identify, measure, monitor and control credit risk (including } \\
\text { counterparty risk). This would include the granting of loans and making of } \\
\text { investments, the evaluation of the quality of such loans and investments, and the } \\
\text { ongoing management of the loan and investment portfolios. }\end{array}$ \\
\hline Des & 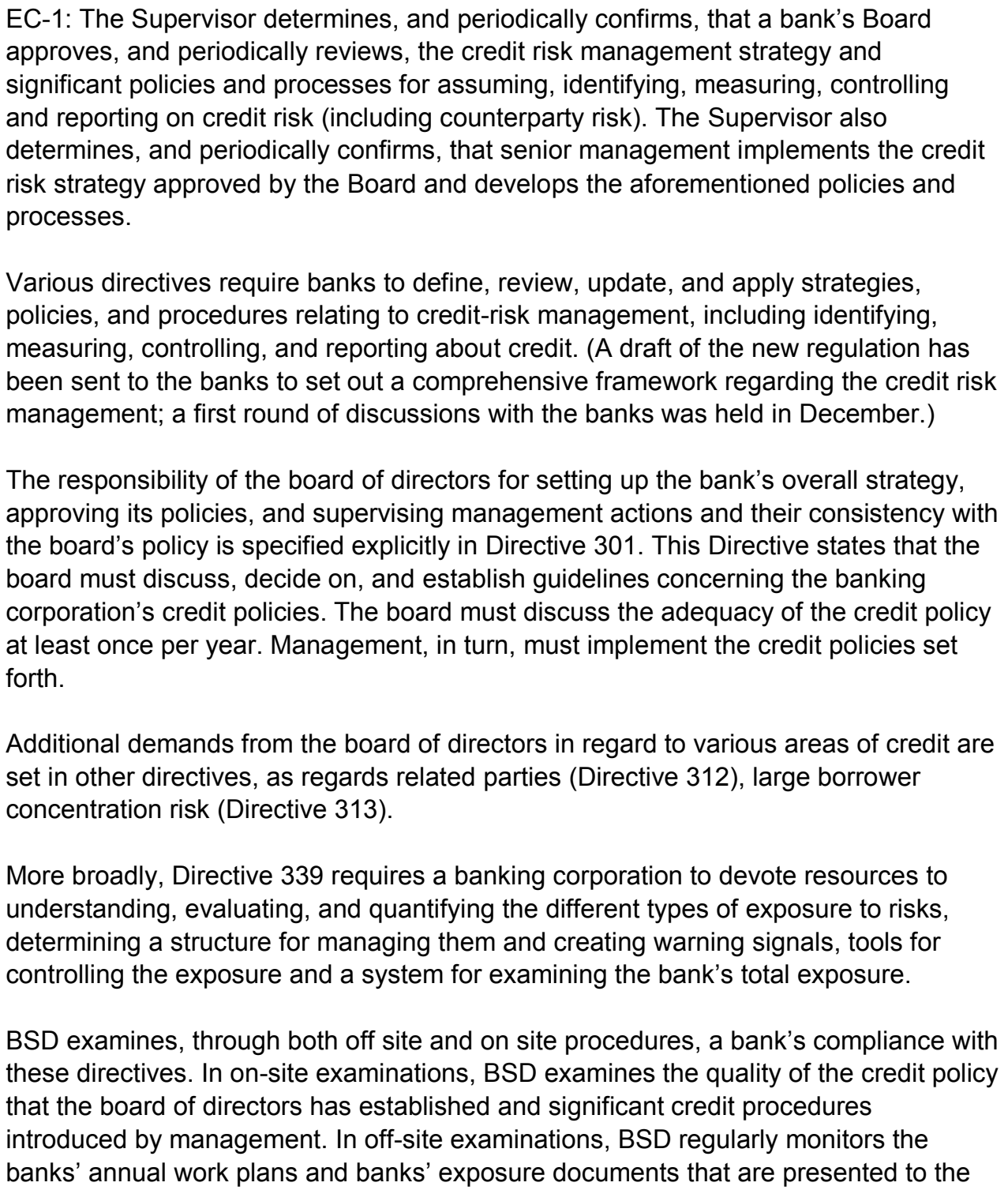 \\
\hline
\end{tabular}


board on a quarterly basis. In addition, through the 'risk matrix' processes, BSD offsite divisions also assess, on a quarterly basis, the quality of credit risk management in each of the bank's material business lines. In this context, the risk-management policies, procedures and strategies are examined, including the processes used for board of directors' approval and ongoing management of this risk by senior management and the risk-management functions.

Within the framework of the SREP (see CP-19), the quality of credit-risk management is also examined (by means of "risk cards") at the levels of the board of directors, management, the $\mathrm{CRO}$, and ongoing management of risk-takers.

EC-2: The Supervisor requires, and periodically confirms, that such policies and processes establish an appropriate and properly controlled credit risk environment, including:

- a well documented strategy and sound policies and processes for assuming credit risk;

- $\quad$ well defined criteria and policies and processes for approving new exposures as well as renewing and refinancing existing exposures, identifying the appropriate approval authority for the size and complexity of the exposures;

- effective credit administration policies and processes, including continued analysis of a borrower's ability and willingness to repay under the terms of the debt, monitoring of documentation, legal covenants, contractual requirements and collateral, and a classification system that is consistent with the nature, size and complexity of the bank's activities or, at the least, with the asset grading system prescribed by the Supervisor;

- comprehensive policies and processes for reporting exposures on an ongoing basis;

- comprehensive policies and processes for identifying problem assets; and prudent lending controls and limits, including policies and processes for monitoring exposures in relation to limits, approvals and exceptions to limits.

The Supervisor's expectations of policies and processes that underlie an appropriate and controlled credit-risk environment are set forth in a large number of directives.

Well documented strategy and sound policies and processes for assuming credit risk:

Banks are required to have well documented strategies and policies (Directive 301), as well as procedures (Directive 316) for the assumption of credit risks, the treatment of collateral, the documentation to be placed in a borrower's file and in the collateral file, and the credit rating to be determined. Directive 317 requires banks to rely on updated financial information for the decision-making in extending or renewing credit. Directive 318 requires them to maintain an up-to-date database of collateral received and its value.

Well defined criteria and policies and processes for approving new exposures as well as renewing and refinancing existing exposures, identifying the appropriate approval authority for the size and complexity of the exposures:

Credit policy should relate to a hierarchy of credit authorities, including approvals of exceptions (see EC-1). Whenever a credit activity is defined as a new product, Directive 339 states that the board of directors shall approve it after having considered all the inherent risks.

Effective credit administration policies and processes, including continued analysis of a borrower's ability and willingness to repay under the terms of the debt, monitoring of documentation, legal covenants, contractual requirements and collateral, and a classification system that is consistent with the nature, size and complexity of the 
bank's activities or, at the least, with the asset classification system prescribed by the Supervisor.

BSD's requirements concerning credit operation and on-going rating of borrowers are anchored mainly in Directive 316 . The internal ratings assigned to problematic borrowers have to be in accordance with the Directive concerning the classification of problem debts (i.e. from January 1, 2011, the classification set forth in the Reporting to Public Directive concerning impaired loans).

In addition, Directive 319 requires examination and/or control of the reliability of the credit ratings to be performed by a dedicated Loan Review Unit. This function should evaluate specific borrower and credit portfolio quality, and provide a basis for the classification of borrowers in accordance with the Supervisor's directives.

\section{Comprehensive policies and processes for reporting exposures on an ongoing basis:}

The requirements are spread across various directives. The reporting to the board of directors is dealt with in Directive 301 (in terms of frequency and content) and Directive 339 (regarding one component of the quarterly reporting, namely the exposures document). The latter Directive also requires a bank to base its risk management system on a computerized management information system which provides comprehensive information on activities and risks.

\section{Comprehensive policies and processes for identifying problem assets:}

The Supervisor has issued directives concerning the treatment of problematic debts from both governance standpoints (Directive 301) and accounting ones (Directive 314 until year-end 2010, and since January 1, 2011, the Reporting to Public Directives concerning impaired loans).

While specifying the accounting rules for financial reporting, BSD has defined precise rules that banks must use in classifying problem assets. (Directive 698A,

Measurement and Detection of Impaired Loans, Credit Risk, and Provision for Credit Losses; the directive was integrated into a detailed directive, No. 660, concerning the annual financial statements.) The framework of the accounting principles was also expanded to include qualitative requirements relating to the process of determining and documenting the credit loss provision (Reporting to Public Directives-Annual Financial Statements). The requirements include the retention of written documentation, the maintenance of an internal control array, the inclusion of a well defined loan review process, the performance of a validation check for the consistency of the method used to estimate the credit loss provision.

\section{Prudent lending controls and limits, including policies and processes for monitoring exposures in relation to limits, approvals and exceptions to limits.}

Directive 301 holds the board of directors responsible for determining risk appetite and desired limits on risk exposure in the credit portfolio. Additional directives $(313,323)$ as well as a large number of supervisory letters pertaining to specific areas of credit and credit risk present further requirements in reference to the setting of limits, a mechanism for the monitoring of limits, and reporting.

For example, due to the financial crisis, BSD instructed the banks to apply greater strictness in examining their risks, including credit risks, with special emphasis on sensitive borrower groups (see Supervisor's letters in 2008 and 2009). A letter from the Deputy Supervisor of Banks in 2009 emphasized certain topics in credit policy and credit operation relating to financing high leverage transactions. Following a sharp increase in mortgage loans and especially adjustable-rate mortgage loans, BSD issued a series of letters that reflected tougher measures with regard to adjustable- 
rate mortgage loans (2009), set out instructions on the management of risks in housing loans and the creation of a supplemental provision (2010), required a larger capital charge for (relatively large) housing loans with more than 60 percent LTV and an adjustable-rate portion equal to or greater than 25 percent (2010), required broader disclosure to the public with regard to exposure to credit risk in housing loans (2011) and prohibited granting housing loans in which the adjustable-rate portion exceeds one third of the loan balance (2011).

In the on-site examinations, the adequacy of credit policies and procedures and the quality of the processes used in credit-risk management and management of controls are examined. The implementation of the Supervisor's directives is also examined. The off-site procedures also include regular review of credit policies and strategies. The quarterly exposure documents provide a snapshot of the exposures, the development of problem debts or the rating of borrowers, and compliance with limits.

EC-3: The Supervisor requires, and periodically confirms, that banks make credit decisions free of conflicts of interest and on an arm's length basis.

The Companies Law establishes arrangements for certain transactions that have the potential of being tainted with conflict of interest. Such types of transactions are those with controlling principals, with other principals, and in which an officer of the corporation has a personal interest.

Directives 312, concerning banking corporation business with related parties, and 301 , concerning the board of directors, augment the general provisions of the law by requiring the banks to conduct business clear of conflict of interest and under market conditions (see CP-11).

EC-4: The Supervisor has full access to information in the credit and investment portfolios and to the bank officers involved in assuming, managing, controlling and reporting on credit risk.

The Banking Ordinance, 1941 empowers the Supervisor and persons acting on $\mathrm{h} / \mathrm{her}$ behalf to require a banking corporation and a director, employee, or external auditor of a banking corporation to present $\mathrm{h} / \mathrm{her}$ with information and documents in their possession relating to the business of the banking corporation and any corporation that it controls, or to allow them to examine, copy, or photocopy any such document. If information is stored in a computer, it must be provided in the manner required.

Banks are required to present BSD with the set of reports set forth in the Reporting to BSD Directives. The set includes regular reports (monthly, quarterly, biannual, annual) in a regular format that contain, among other things, extensive information about credit and securities portfolios—size, return, loss provisions, etc

AC-1: The Supervisor requires that the credit policy prescribes that major credit risk exposures exceeding a certain amount or percentage of the bank's capital are to be decided by the bank's senior management. The same applies to credit risk exposures that are especially risky or otherwise not in line with the mainstream of the bank's activities.

There is no explicit requirement in BSD's regulations that the senior management must approve credit that exceeds a certain amount or exceptionally risky exposures. (This requirement is included in the credit risk management draft directives.)

New products entail a process of approval by the board of directors after the board considered all the risks involved in it, examines the mechanism that the bank will use to manage, measure, and control the risks, and sets quantitative limits commensurate 


\begin{tabular}{|c|c|}
\hline & 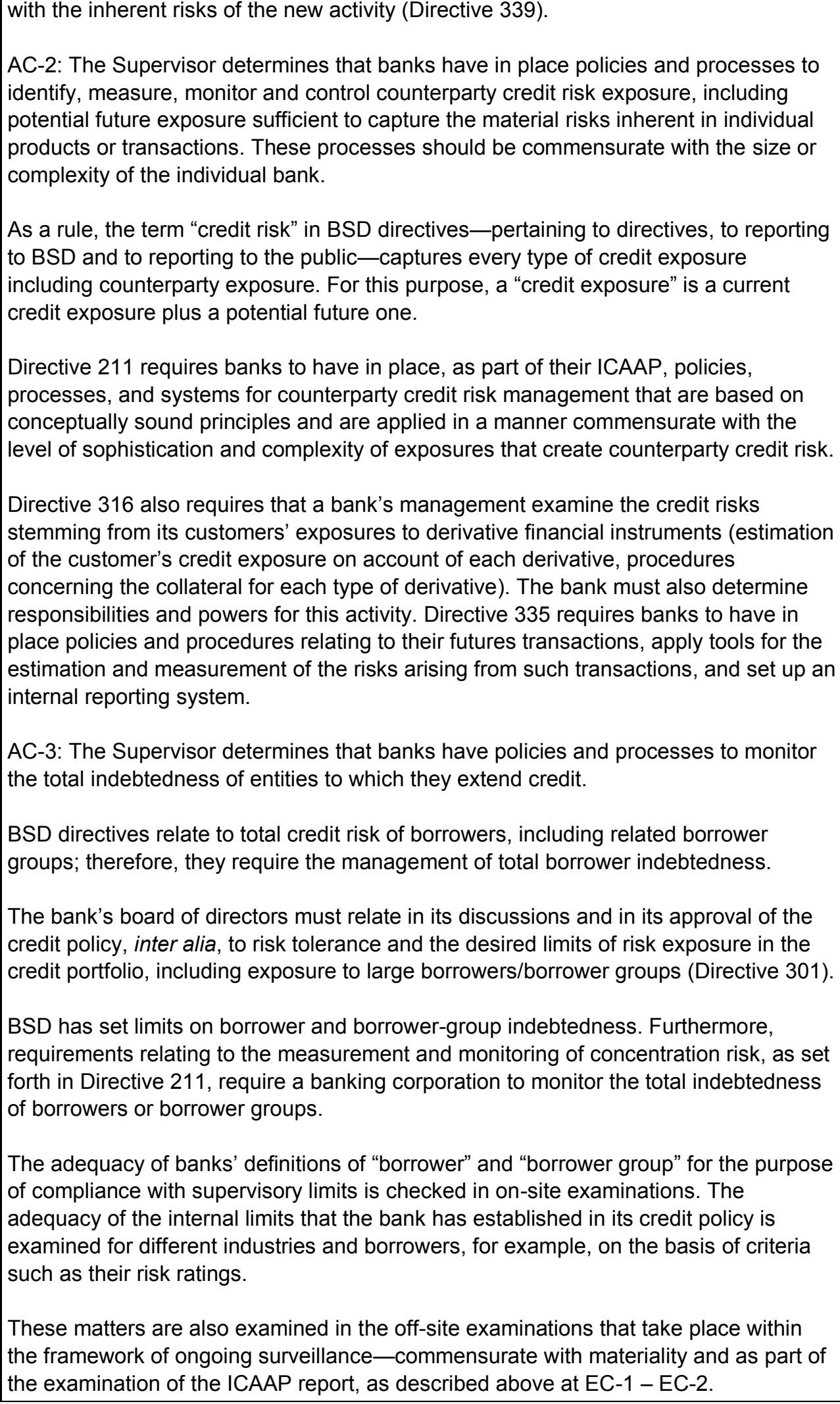 \\
\hline Assessment & Compliant \\
\hline Comments & $\begin{array}{l}\text { Over time, in the wake of the on-site examinations and the release international } \\
\text { standards, the Supervisor has issued a large number of detailed directives concerning } \\
\text { credit risk management processes which include risk appetite and credit policy, } \\
\text { related parties, monitoring mechanisms by various organs in a bank, evaluation of } \\
\text { quality of loans and investments, and ongoing management of loan and investment }\end{array}$ \\
\hline
\end{tabular}


portfolios. Only recently has BSD started a process of forming an updated and comprehensive regulation concerning credit risk management. BSD is commended for this recent initiative and, going forward, is encouraged to ensure that this new regulatory rulebook will be maintained in a comprehensive manner.

BSD performs an intensive oversight of the credit risk borne by banks. This is done both from an off-site perspective, based on very detailed and frequent reporting, and from an on-site standpoint. 41 examinations have been conducted in respect of credit risk since 2006, with a twofold objective, namely the assessment of policies and procedures and the checking of specific transactions. Thematic examinations have been performed in a range of credit-related fields, such as large borrowers in the banking system, mortgage lending, leveraged credit, problem debt detection and classification processes.

BSD should take the opportunity of the upcoming overhaul of its regulation regarding risk management to incorporate guidelines for sound internal rating practices. The current guidance in this field is very limited, so that the banks may not necessarily feel incentivized to upgrade their practices and BSD may lack a regulatory basis to request them to do so. Accordingly, there seems to be a strong case for initiating an iterative process, whereby BSD would prescribe guidelines for sound internal rating systems, on the basis of which it could, first, benchmark and assess the banks' practices and, second, use the outputs of internal-ratings based information for the purpose of a more forward-looking supervision. In the longer term, such improvements in the banks' practices and BSD's knowledge in this area could pave the way for an implementation of advanced approaches for capital purposes as well.

Regulation should require senior management to approve credit that exceeds a certain amount or exceptionally risky exposures.

Principle 9. $\quad$ Problem assets, provisions and reserves. Supervisors must be satisfied that banks establish and adhere to adequate policies and processes for managing problem assets and evaluating the adequacy of provisions and reserves.

Description

EC-1: Laws, regulations or the Supervisor require banks to formulate specific policies and processes for identifying and managing problem assets. In addition, laws, regulations or the Supervisor require periodic review by banks of their problem assets (at an individual level or at a portfolio level for credits with homogenous characteristics) and asset classification, provisioning and write-offs.

Reporting to Public and Proper Conduct of Business Directives determine the processes that banks must apply in identifying, classifying, and managing problem debts, recording interest revenues on account of problem debts, writing off debts, and making credit loss provisions. On January 1, 2011, substantial changes relating to the classification of problem debts (Reporting to Public), including nonaccrual impaired debts and debts to be written off, have been introduced.

Banks must grade their exposures or borrower, on an ongoing basis (Directive 316) and a Loan Review function must review credit and ensure the appropriateness of its rating and the methods used to rate borrowers who are not examined on an individual item basis (Directive 319). Further, Directive 301 states that the management and board of directors of every bank must make sure that the bank has a set of effective controls for credit control and that debts are written off as soon as information verifying that they are uncollectible becomes available. The board must review and approve, on a quarterly basis, the balance of the credit loss provision and credit loss expenditure that are reported in the financial statements. When the board discusses credit policy, it must address provisioning and debt classification policy

Reporting to Public directives state, inter alia, that banks must apply a well defined process of credit control review, must consistently apply an effective credit rating 
system that identifies various risk characteristics and credit quality problems in an accurate and timely manner and requires rapid and appropriate managerial actions. They also state a bank must maintain a credit loss provision that adequately covers estimated credit losses relating to its credit portfolio.

(A draft of a new regulation has been sent to the banks to set out a comprehensive framework regarding the credit risk management, including the Processes of classification and provisioning, and will ensure full consistency of the relevant rules in this area.)

EC-2: The Supervisor confirms the adequacy of the classification and provisioning policies and processes of a bank and their implementation; the reviews supporting this opinion may be conducted by external experts.

The classification and provisioning processes are reviewed in on-site examinations. These examinations, performed at the banks' business and control departments, cover aspects of adequacy and deficiencies and inspect specific borrowers via a sample of borrower files. In addition, BSD uses the SREP framework to assess banks' inherent risk and the quality of control with regard to credit, by assessing the bank's material processes, including those relating to the extension, classification, and provisioning of credit, the assessment of the bank's asset quality, and the appropriateness of classification and credit loss provisioning. BSD also assesses the quality of a bank's credit processes on the basis of external auditors' work.

EC-3: The system for classification and provisioning takes into account off-balance sheet exposures.

Reporting to Public Directives, concerning credit loss provisioning on account of offbalance-sheet credit instruments, explicitly state that banks must maintain an appropriate provision to cover expected credit losses on account of off-balance-sheet credit instruments, such as credit commitments and guarantee contracts, in accordance with the rules set forth in FAS 5 . A banking corporation may not wait until the off-balance-sheet credit instruments are realized to recognize the loss [...].

EC-4: The Supervisor determines that banks have appropriate policies and processes to ensure that provisions and write-offs reflect realistic repayment and recovery expectations.

According to the new Reporting to Public directives, irrespective of the method that it uses to determine a credit loss provision, a bank must develop and document a consistent method for the determination of credit loss expense and the balance of the credit loss provision on any reporting date. It must ensure that the total balance of the credit loss provision appropriately covers the risk in a conservative and prudent way. Banks must especially pay attention to debts that are analyzed on an individual item basis and that were assigned provisions lower than previously accepted levels for groups of similar debts.

The Reporting to Public directives require the write-off of debts that are so unlikely to be recovered that it becomes inappropriate to recognize them as assets-even if some recovery will occur at some future time. The directives include detailed guidance on write-off of small homogeneous debts on the basis of the duration of their arrears and detailed guidance on the write-off of large debts, including those whose recovery is conditioned on collateral.

BSD requires banks to assess the size of their credit loss provision as of the end of each quarter. The provision should be based on the bank's current assessment of the credit quality of its loan portfolio and should take into account the relevant external 
and internal variables that affect the recoverability of the debt.

EC-5: The Supervisor determines that banks have appropriate policies and processes, and organizational resources for the early identification of deteriorating assets, for ongoing oversight of problem assets, and for collecting on past due obligations.

Reporting to Public directives set out compulsory principles for the classification and identification of problem debts. In addition, Directive 316 requires ongoing rating of debts. Directive 319 instructs the credit control function to perform loan review, make sure that debts are rated appropriately, and review the rating methods for borrowers not examined on an individual item basis.

BSD uses on-site and off-site examinations to inspect policies and processes, the quality and quantity of the resources that a bank invests in complying with the aforementioned directives, the bank's use of credit rating systems, and the functioning of loan review.

EC-6: The Supervisor is informed on a periodic basis, and in relevant detail, or has access to information concerning the classification of credits and assets and provisioning.

The Reporting to Public Directives define the financial information that must be made publicly available on a quarterly/annually basis. This information includes, among other things, detailed quarterly information about classifications of debt, arrears, reorganization of problem debt, write-offs, and credit loss provisioning. In addition, the Reporting to BSD directives require more detailed quarterly information about classifications of debts, arrears, reorganization of problem debt, write-offs and credit loss provisioning, and similar information about large borrowers and large borrower groups.

Immediate report to BSD is required whenever all or a part of a debt that exceeds 5 percent of the banking corporation's capital is classified as doubtful (Directive 301).

As examinations are being performed, the examiners enjoy full access to all bank data and staff, including individual credit portfolios of private and corporate borrowers, borrowers' personal wealth statements, internal and external audit reports, minutes of management and board meetings, and reports presented to these organs.

EC-7: The Supervisor has the power to require a bank to increase its levels of provisions and reserves and/or overall financial strength if it deems the level of problem assets to be of concern.

If BSD believes that a bank's provisions-for specific customers and for credit portfolio risks-are inadequate, it has the power to require the bank to increase them (Banking Ordinance, 1941).

The Reporting to Public directives prescribe the way in which credit loss provisions and write-offs of problem debts must be made, on an individual basis.

BSD is in the process of issuing guidelines for group provisions. But it already requires banks to make appropriate provisions at the portfolio level whenever it finds the lack of adequate consideration of a material risk in provisioning, e.g. for housing loans (based on a formula determined by the Supervisor according to the depth of delinquency).

BSD may also assign a higher capital charge on certain assets (e.g. MBS exposures) if it believes that the extent of these assets is troubling or if it considers the level of risk undesirably high. 
EC-8: The Supervisor assesses whether the classification of the credits and assets and the provisioning is adequate for prudential purposes. If provisions are deemed to be inadequate, the Supervisor has the power to require additional provisions or to impose other remedial measures.

The Supervisor is empowered to demand remedial measures in the event of inadequate provisions or inappropriate classifications (see EC-7). In its off-site and onsite activities, BSD assesses the adequacy of the classification and provisioning processes.

EC-9: The Supervisor requires banks to have appropriate mechanisms in place for periodically assessing the value of risk mitigants, including guarantees and collateral. The valuation of collateral is required to reflect the net realizable value.

Directive 316 requires banks to have a procedure for the treatment of collateral, e.g. intake, documentation, assessment, inspection, and revaluation. Also, they must have an up-to-date information system about collateral obtained and its value (Directive 318).

BSD's Reporting to Public Directives set out additional rules in this matter.

EC-10: Laws, regulations or the Supervisor establish criteria for assets to be identified as impaired, e.g., loans are identified as impaired when there is reason to believe that all amounts due (including principal and interest) will not be collected in accordance with the contractual terms of the loan agreement.

According to the Reporting to Public Directives, a debt is identified as impaired when, based on updated information and events, it is probable that the bank will be unable to collect all the amounts owing to it under the contractual terms of the debt agreement.

In any case, it will be classified as such when the payment of its principal or interest is overdue by 90 days or more, unless it is well-secured and also in the process of collection. A debt is considered to be well-secured if it is secured by collateral or a guarantee of a financial responsible party. It is considered to be in the process of collection if its collection is being carried out in due course through a legal proceeding or collection efforts are expected to lead to the redemption of the debt in the near future, in general within 30 days, unless there is reasonable certainty regarding the date and amount of collection.

BSD examines the booking of specific loans in accordance with its directives.

EC-11: The Supervisor determines that the Board receives timely and appropriate information on the condition of the bank's asset portfolio, including classification of credits, the level of provisioning and major problem assets.

BSD directives include various reporting requirements to the board of directors and management. According to Directive 301, the board of directors must receive monthly reports about the treatment of hard-to-collect debts of material size and, in the quarterly report, to obtain details about loan-loss provisions. Under Directive 339, the "exposures document," which relates to credit risks among other things, must be placed before the board of directors and management in any discussion where decisions are made and changes in the desired composition of the banking corporation's risks are determined. This "exposures document" is discussed at least once every quarter. According to Directive 319 , the head of the loan review function sends a report to the board of directors at least once a year. 


\begin{tabular}{|c|c|}
\hline & 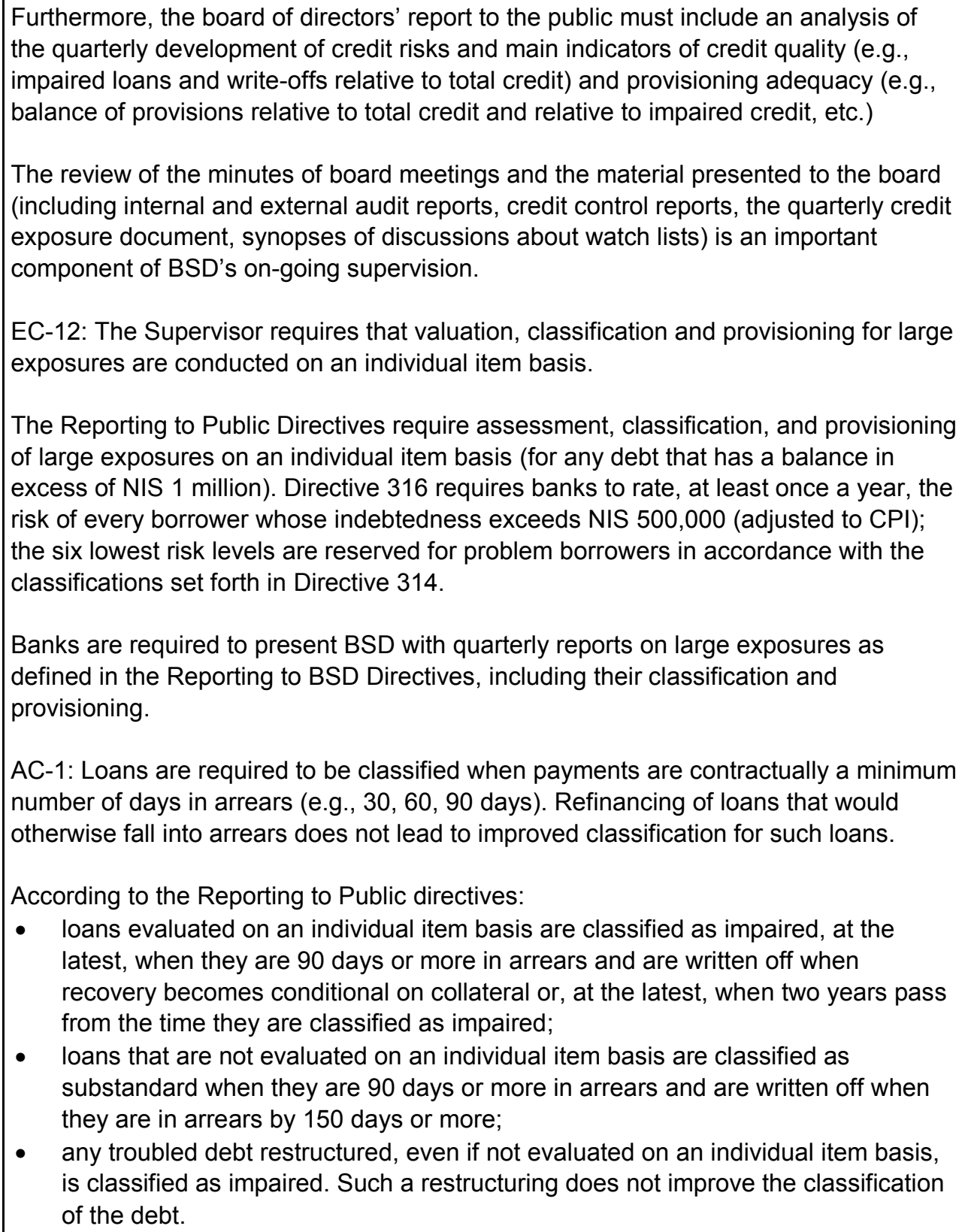 \\
\hline Assessment & Compliant \\
\hline Cor & $\begin{array}{l}\text { The implementation of the new rules regarding problem debt classification and } \\
\text { provisioning dates back to January } 2011 \text {, based on Reporting to Public directives. Yet, } \\
\text { the regulatory framework still needs a comprehensive review, in order to ensure full } \\
\text { consistency of the relevant rules in this field, especially in respect of Directive } 314 \text {. } \\
\text { The current classification of past due debt (defined as when the payment of principal } \\
\text { or interest is overdue by } 90 \text { days or more, unless it is well-secured and in the process } \\
\text { of collection) as impaired is still biased by the allowance for collateral realization. Even } \\
\text { though some criteria are set forth in order to allow acknowledgement of a process of } \\
\text { collection, the present wording of the definition still leaves much room for discretion to } \\
\text { assess criteria such as an expected recollection "in due course through a legal } \\
\text { proceeding", "collection efforts expected to lead to the redemption of the debt in the } \\
\text { near future", in general within } 30 \text { days, unless there is "reasonable certainty" regarding } \\
\text { the date and amount of collection. } \\
\text { Accordingly, the classification as impaired of past due debts is unlikely to include all } \\
\text { the debts where there is reason to believe that all amounts due will not be collected in }\end{array}$ \\
\hline
\end{tabular}


accordance with the contractual terms of the loan agreement, in view only of the borrower's creditworthiness and regardless of collateral.

Against this background, BSD is invited to consider fine-tuning the classification regime, in order to single out, within the category of impaired debts, those debts which are unlikely to be collected in view only of the borrower's creditworthiness, before allowing for collateral realization.

Fine-tuning the definition of impaired debts as suggested should help banks to ensure convergence of the accounting classification and the Basel II internal ratings-based definition of borrowers in default. Accordingly, it would facilitate their move to IRB for regulatory capital purposes in the longer term.

Principle 10. $\quad$ Large exposure limits. Supervisors must be satisfied that banks have policies and processes that enable management to identify and manage concentrations within the portfolio, and supervisors must set prudential limits to restrict bank exposures to single counterparties or groups of connected counterparties.

\begin{tabular}{l|l} 
Description & BSD directives set prudential limits on large exposures, both on and off-balance
\end{tabular} sheet. They require banks to identify large exposures, including connected counterparties, to set internal limits on them, to establish effective controls, clear responsibility, and reporting channels. They also require banks to report large exposures to BSD. In the course of off and on-site examinations, BSD reviews the banks compliance with these directives.

EC-1: Laws or regulations explicitly define, or the Supervisor has the power to define, a "group of connected counterparties" to reflect actual risk exposure. The Supervisor may exercise discretion in applying this definition on a case-by-case basis.

Directive 313 deals with limits to borrower and borrower-group indebtedness. Within this framework, the following terms are defined: "borrower", "a group of borrowers", "a banking group of borrowers" and "a controlled group of borrowers". These definitions rely on criteria that relate either to control of ownership or to the existence of economic or financial interconnections. They allow some discretion in placing borrowers in a group or treating several legal entities as a solo borrower, but Directive 313 also gives the Supervisor general power to define a borrower as part of a borrower group and to leave a borrower out of a borrower group.

The limits established in the directive apply to the total indebtedness of a borrower and a borrower group to a banking corporation and to all corporations, in Israel and abroad, whose financial statements are consolidated with the financial statements of the banking corporation.

The directive applies to all banks. It was updated in 2011, among other things, to subject indebtedness of banks to regulatory limits, to make the limit on cumulative exposure to large borrowers more stringent (see EC-2) and revise the rules for calculating indebtedness on account of over-the counter (OTC) derivatives.

EC-2: Laws, regulations or the Supervisor set prudent limits on large exposures to a single counterparty or a group of connected counterparties. "Exposures" include all claims and transactions, on-balance sheet as well as off-balance sheet. The Supervisor confirms that senior management monitors these limits and that they are not exceeded on a solo or consolidated basis.

The regulatory limits (set forth by Directive 313) on borrower and borrower-group indebtedness to a banking corporation are minimum rules. The bank must discuss and set internal limits in view of, inter alia, its own characteristics, those of its exposures, credit rating levels, and the extent of correlation between the borrowers included in a borrower group and the total level of credit concentration at the bank and the banking 
group.

Various regulatory limits on large exposures have been in force for some time. Amended regulatory limits (in force from January 2012 but phased in over two years) are set as follows:

- A (non-banking) borrower's net indebtedness shall not exceed 15 percent of the bank's capital.

- A borrower group's net indebtedness shall not exceed 25 percent of the bank's capital.

- A banking borrower group's net indebtedness shall not exceed (1) 25 percent of the bank's capital or (2) NIS 250 million, whichever is greater.

- A controlled borrower group's net indebtedness shall not exceed 50 percent of the bank's capital.

- The total net indebtedness of all "borrowers", "groups of borrowers", and "banking group of borrowers", whose net indebtedness exceeds 10 percent of the bank's capital, shall not exceed 120 percent of the bank's capital. (Previously, the sum of the six largest exposures to nonbank borrowers could not exceed 130 percent of capital.)

The Supervisor is empowered to set limits on intra-group exposures, though currently there are no such limits (this is based on the general powers of the Supervisor to issue prudential standards that banks must meet, which were exercised, for example, in issuing Directives 312 and 313).

The indebtedness includes, inter alia, credit, investment in a borrower's securities, commitments to pay money on a customer's account, transactions in OTC derivatives, commitments to extend credit or issue a guarantee, commitments to the "Maof" Clearinghouse and 50 percent of some other off-balance sheet commitments. The indebtedness does not include sums for which an accounting write-off has been performed or a credit-loss provision on individual basis has been made. The indebtedness of a banking borrower group does not include banks' overnight deposits and settlement balances.

The net indebtedness is defined as indebtedness less permissible deductions (deposits recognized as collateral - without any maturity mismatch, indemnifications by the State of Israel or multilateral financial institutions, guarantees from Israel Export Insurance Company or public sector entities weighted at 0 percent for capital adequacy purposes, 90 percent of the market value of traded debt securities issued by the State of Israel or sovereigns weighted at 0 percent for capital adequacy purposes).

The Supervisor may approve exceptions to the limits.

A banking corporation's management must establish, with approval of the board of directors, written procedures for the monitoring of large-borrower concentration risk, which includes at least the existence of a data-collection system, an internal control system for the identification of connections among borrowers and a monitoring of the development of large borrowers' indebtedness, including periodic reporting to the board of directors even when indebtedness does not exceed the limit. These procedures should determine the authority required to increase borrowers' indebtedness and the threshold of indebtedness requiring monitoring.

Banks must report to the Supervisor every three months, on both a consolidated and a solo basis (but the limits apply on a consolidated basis only). Borrower indebtedness that exceeds the limits should be reported within seven days. Banks must also report to the Supervisor semi-annual information on intra-group exposures (see CP-11). 
In the course of its off-site examination, BSD verifies the governance of the limits policy (approval by the senior management, compliance with the requirement to discuss and, if need be, set more stringent internal limits). In its on-site examinations, BSD makes sure that the bank monitors its exposures and has appropriate controls and a management information system in place to avoid infringements. BSD examines whether the bank's loan issuing policies and processes comply with directives and demands corrective action if faults are found in policies, processes, working methods, or internal control.

EC-3: The Supervisor determines that a bank's management information systems identify and aggregate on a timely basis exposure to individual counterparties and groups of connected counterparties.

The requirement to have a management information system for the identification and aggregation of exposures is anchored in Directive 313.

Banks report their large exposures to BSD (see EC-5), which performs logical checks on the composition of the groups (including comparison of different banks' definition of groups) and compliance with limits. In its on-site examinations, BSD also checks whether the banks' reports on lending to groups are credible and whether the reporting process is well defined.

EC-4: The Supervisor confirms that a bank's risk management policies and processes establish thresholds for acceptable concentrations of credit and require that all material concentrations be reviewed and reported periodically to the Board.

Directive 301 requires the board to discuss and approve, within the framework of credit policy, risk tolerance and desired limits to the level of exposure to risk in the credit portfolio, including exposure on account of sectoral concentration, largeborrower and borrower-group exposure, exposure by credit-rating groups, exposure by target markets; geographic exposure; currency exposures; and exposure by maturity, and concentration of collateral.

Directive 211 requires that banks, as part of their capital adequacy assessment, address the management of credit concentration risk. Thus, banks should have documented and effective policies, systems, and internal controls in place for the identification, measurement, monitoring, and control of credit risk concentrations. These policies should cover and define the different forms of credit risk concentrations to which a banking corporation may be exposed. The limits must be defined relative to the bank's capital, total assets, or, where adequate measures exist, its total level of risk. Furthermore, the bank should act in a manner that will assure compliance with the supervisory guidelines relating to credit risk concentrations, including those specified in the Basel document Principles for the Management of Credit Risk (September 2000).

Additionally, where borrower concentration is concerned, the regulatory limits set out by Directive 313 should be considered as minimum rules. This directive requires banks to set more stringent limits, if appropriate (see EC2), and maintain ongoing monitoring, at the management and board of directors' levels, of compliance with the limits and the development of the bank's exposure to large borrowers, even when indebtedness does not exceed limits.

As for sectoral concentration of indebtedness, effective January 1, 2011, the Reporting to Public Directives require a bank must to take into account, when calculating group credit loss provisions, the effects of changes in credit concentration among other factors. The requirement to make a supplemental provision, including 
one on account of sectoral concentration of indebtedness, has become a minimum floor for the calculation of the collective provision.

BSD reviews banks' policies, the minutes of board and board committee meetings, and background material for the discussions, including quarterly "exposures documents". In the course of its on-site examinations, BSD demands and makes sure that a qualitative control process concerning concentration is applied commensurate with the complexity of the bank's credit activity, its risk appetite, and its level of capital, including processes for the approval of exceptions to the policies.

EC-5: The Supervisor regularly obtains information that enables concentrations within a bank's portfolio, including sectoral, geographical and currency exposures, to be reviewed. The Supervisor has the power to require banks to take remedial actions in cases where concentrations appear to present significant risks.

BSD receives quarterly reports on large credit exposures (within the meaning of Directive 313), on revenues, net earnings, and assets, parsed by operating sectors and geographical regions, on credit for financing of the acquisition of control or means of control in corporations, on credit risk according to industry sectors, on exposure to foreign financial institutions, on exposure to foreign countries, on borrowers who have credit risk in foreign currency. On a monthly basis, it receives reports on lending to the construction and real-estate industry and on assets and liabilities (including credit) by types of indexation.

The banks' public financial statements include, in accordance with BSD's directives, information about concentrations of exposures in the banks' portfolios.

BSD may request any additional information that it needs to analyze and evaluate credit concentrations at an individual bank or in the banking system. The Supervisor is empowered to order banks to take corrective measures when he considers an excessive concentration as likely to impair the bank's ability to meet its obligations or the proper conduct of its business.

BSD performs quarterly monitoring of banks' exposure to large borrowers by means of a data-analysis system. Banks' exposures to large borrowers in foreign currency and their concentration in specific industries (e.g. real estate) are also monitored on a quarterly basis. In its examination of the ICAAP reports, BSD reviews the internal models that the banks use to estimate concentration in their credit portfolio. Where necessary, the banks are advised (in the letter concerning the ICAAP report) that the model underestimates the concentration or is faulty. Within the SREP framework, BSD examines, by means of a "risk card," indicators of the following kinds of credit concentration: sectoral, borrower, products (foreign financial institutions, means of control, and mortgage-loan indebtedness), and geographic. In this context, BSD requires a supplemental capital charge in case of aberrant concentration in the credit portfolio or even a reduction of excessive exposure. At the system level, in the field of mortgage loans, BSD recently ordered the banks to reduce their exposure to adjustable-rate mortgage lending and ordered new loans that include an adjustable rate component not to exceed one-third of the total mortgage balance.

AC-1: Banks are required to adhere to the following definitions:

- ten percent or more of a bank's capital is defined as a large exposure; and

- twenty-five percent of a bank's capital is the limit for an individual large exposure to a private sector non-bank counterparty or a group of connected counterparties.

Minor deviations from these limits may be acceptable, especially if explicitly temporary or related to very small or specialized banks.

Banks in Israel are required to comply with these limits, as specified in EC-2. 


\begin{tabular}{|c|c|}
\hline Assessment & Compliant \\
\hline Comments & $\begin{array}{l}\text { Based on comprehensive regulation, BSD makes sure that management correctly } \\
\text { defines, measures, monitors, and controls large credit exposures or concentrations of } \\
\text { other kinds (by sectoral, by geographic area, by collateral and by product). } \\
\text { The policy and the supervisory practice in the area of credit concentration risk are } \\
\text { driven by a single-name/entity/sector approach, which does not give the ability to look } \\
\text { through the entities, sectors or geographic regions singled out for reporting purposes. } \\
\text { As a result, banks and BSD might fail to capture the concentration risk that arises from } \\
\text { distinct but correlated exposures. BSD is strongly recommended to incentivize the } \\
\text { banks to devote more attention to concentration of risk factors, beyond single-name } \\
\text { concentration, and to incorporate such analysis in the context of its own SREP } \\
\text { processes. }\end{array}$ \\
\hline Principle 11. & $\begin{array}{l}\text { Exposures to related parties. In order to prevent abuses arising from exposures } \\
\text { (both on balance sheet and off balance sheet) to related parties and to address } \\
\text { conflict of interest, supervisors must have in place requirements that banks extend } \\
\text { exposures to related companies and individuals on an arm's length basis; these } \\
\text { exposures are effectively monitored; appropriate steps are taken to control or mitigate } \\
\text { the risks; and write-offs of such exposures are made according to standard policies } \\
\text { and processes. }\end{array}$ \\
\hline Description & 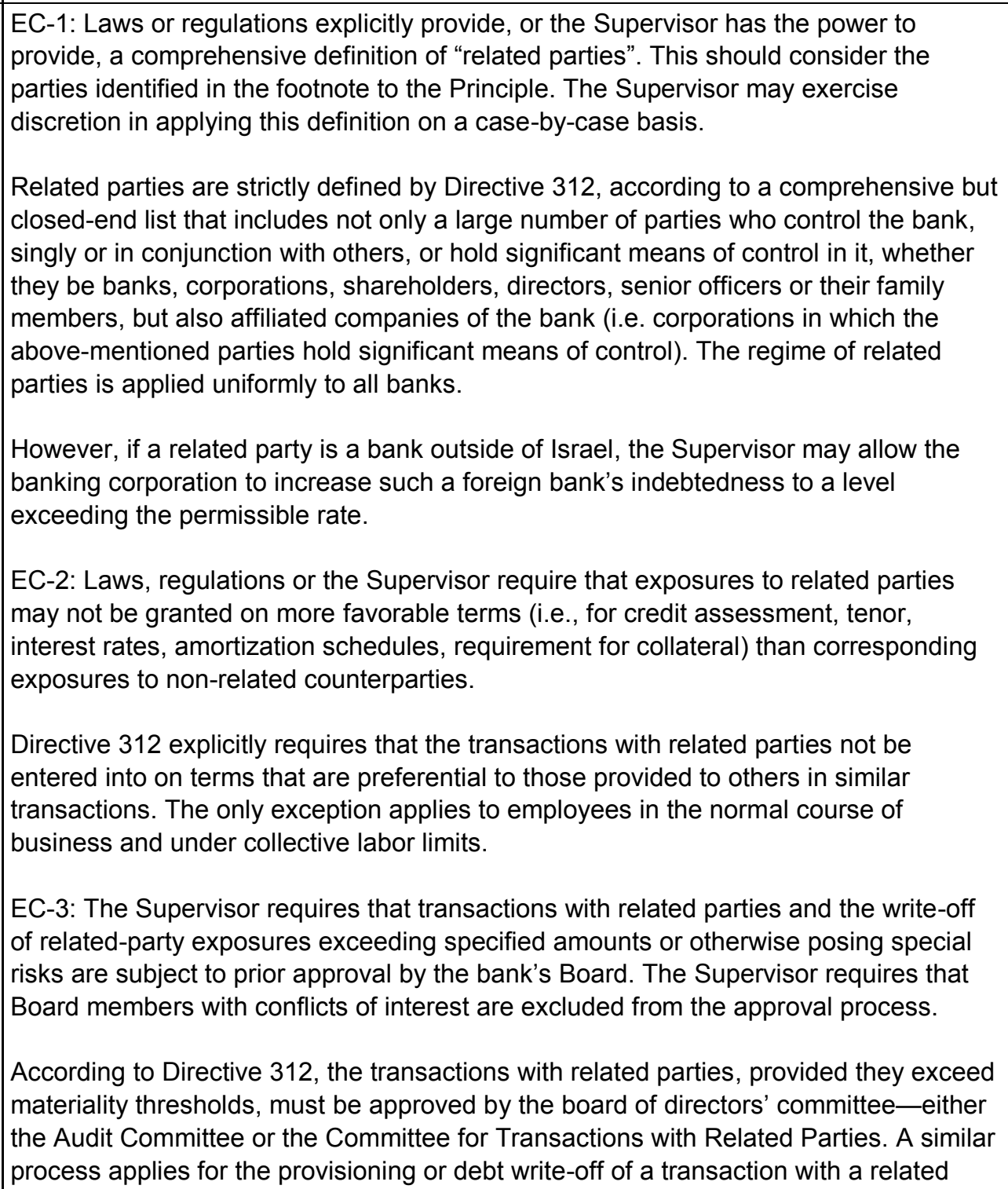 \\
\hline
\end{tabular}


party.

According to Directive 301, a director who has a direct or indirect personal interest in a transaction is bound to declare his personal interest, and prevented from receiving information concerning that interest, attending the board's meeting, and voting on a decision in this matter. More broadly, this directive specifies that, in case of conflict of interest due to his linkage with a corporation that operates in the same specific subsector as a customer, a director shall not participate in the board of directors' discussions in this matter and shall not receive information and reports relating to that customer.

The process applied to transactions with controlling principals, principals and officers is also governed by the Companies Law, which sets certain procedures for approval of the board. .

EC-4: The Supervisor requires that banks have policies and processes in place to prevent persons benefiting from the exposure and/or persons related to such a person from being part of the process of granting and managing the exposure.

Directive 301 establishes the principle that directors should not be involved in the process of executing a transaction in which they have a personal interest. However, no directives demand explicitly that an officer, who is not a director, not be involved in the origination or the management of a transaction (this requirement is included in the credit risk management draft directives, which were sent to the banks for a first round of discussions which was held in December 2011).

EC-5: Laws or regulations set, or the Supervisor has the power to set on a general or case-by-case basis, limits for exposures to related parties, to deduct such exposures from capital when assessing capital adequacy, or to require collateralization of such exposures. When limits are set on aggregate exposures to related parties, these are at least as strict as those for single counterparties, or groups of connected counterparties.

Directive 312 sets out the principle whereby the total aggregate indebtedness of all related parties shall not exceed 10 percent of the bank's capital at any time. This limit is more stringent than the limit applying to single-borrower indebtedness (15 percent) and the limit applying to borrower-group indebtedness ( 25 percent).

In addition to these limitations on the exposures to related parties, Directive 312 imposes limits on the indebtedness of members of a bank's core controlling shareholders, i.e. the "group" (see EC1). The indebtedness of all the components of the "group" to the banking corporation shall not exceed 10 percent of the banking corporation's capital at any time. When the indebtedness of a component in the group is mainly to the same banking corporation, the indebtedness of that component shall not exceed the amount obtained by multiplying its relative share in the core holding by 10 percent of the banking corporation's capital.

The Supervisor has not established rules for the deductions from capital of the indebtedness of related persons. The Supervisor has not issued specific requirements for putting up collateral against such indebtedness. However, since a banking corporation may not conclude a transaction with a related person that is not at arms'length basis, it is expected to obtain appropriate collateral against the credit extended as in most credit transactions.

EC-6: The Supervisor requires banks to have policies and processes to identify individual exposures to related parties as well as the total amount of such exposures, and to monitor and report on them through an independent credit review process. The 


\begin{tabular}{|c|c|}
\hline & 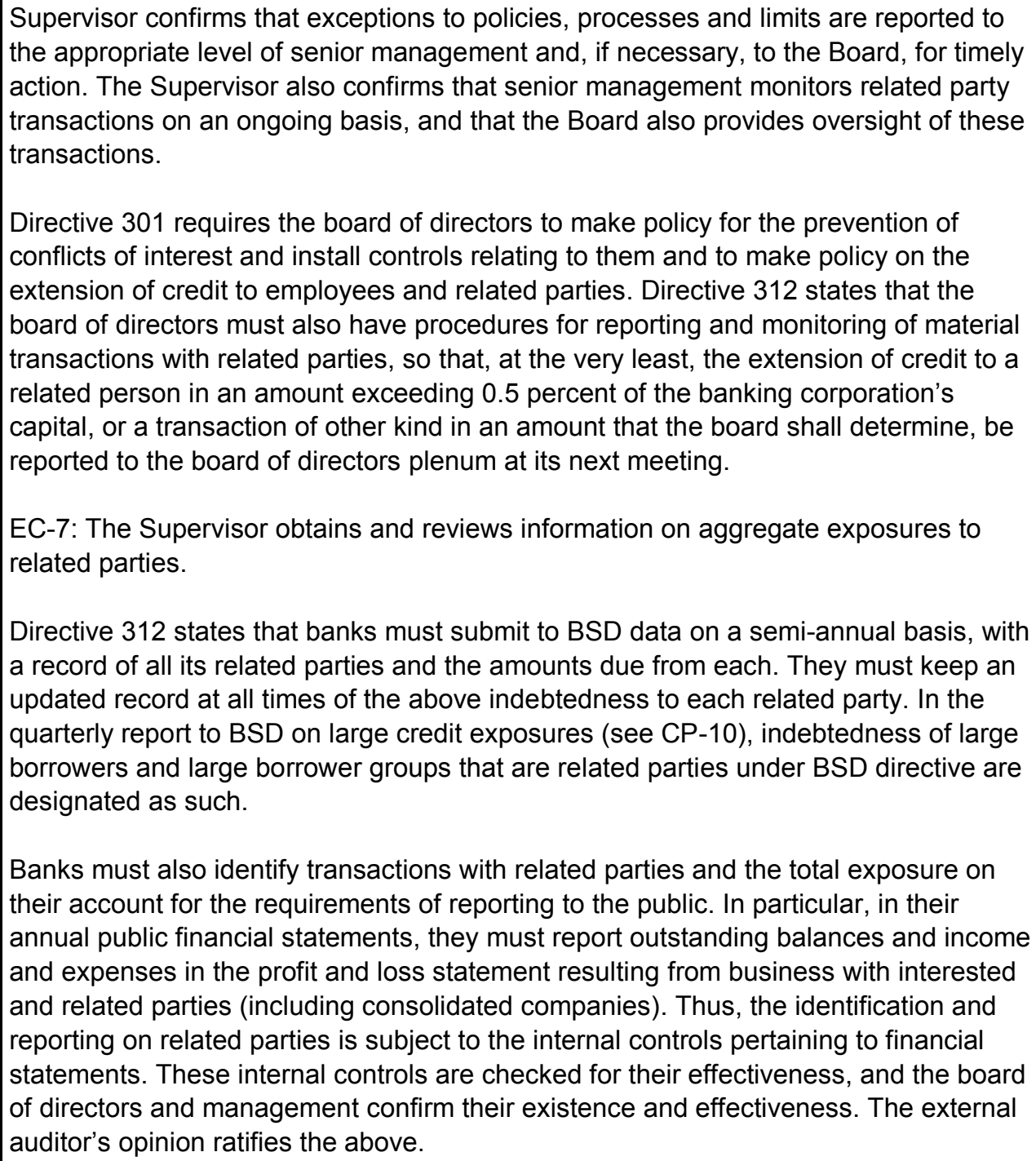 \\
\hline Assessment & Compliant \\
\hline ments & $\begin{array}{l}\text { The list of related parties is large, but closed and based on very precise criteria, so } \\
\text { that it does not provide the Supervisor with sufficient discretion to apply the definition } \\
\text { (EC1). Worth noting, however, is that the definition of related parties includes not only } \\
\text { parties who individually control the bank, but also those who control it in conjunction, } \\
\text { as a group of core controlling shareholders. } \\
\text { The Supervisor should also be able to demand explicitly that an officer, who is not a } \\
\text { director, not be involved in the origination or the management of a transaction. } \\
\text { While not essential, consideration could be given to the establishment of rules for the } \\
\text { deduction of related party lending from regulatory capital or collateralization of such } \\
\text { exposures. }\end{array}$ \\
\hline Principle 12. & $\begin{array}{l}\text { Country and transfer risks. Supervisors must be satisfied that banks have adequate } \\
\text { policies and processes for identifying, measuring, monitoring and controlling country } \\
\text { risk and transfer risk in their international lending and investment activities, and for } \\
\text { maintaining adequate provisions and reserves against such risks. }\end{array}$ \\
\hline Description & $\begin{array}{l}\text { EC-1: The Supervisor determines that a bank's policies and processes give due } \\
\text { regard to the identification, measurement, monitoring and control of country risk and } \\
\text { transfer risk. Exposures are identified and monitored on an individual country basis (in } \\
\text { addition to the end-borrower/end-counterparty basis). Banks are required to monitor } \\
\text { and evaluate developments in country risk and in transfer risk and apply appropriate }\end{array}$ \\
\hline
\end{tabular}


countermeasures.

BSD directives refer to the management of country risk mainly within the framework of concentrations of credit risk. The directives require the setting of policies, procedures, and processes for the management of credit risk, including country risk (see CP-8).

In its discussion of credit policy, the board of directors must address, among others, risk tolerance and desired limits to the level of exposure to risk. This includes exposures to target markets, geographic exposure and exposures to currencies (Directive 301).

As part of its ICAAP, a bank must have effective internal policies, systems, and controls to identify, measure, monitor, and control credit risk concentration. This explicitly applies, among others, to those concentrations arising from credit exposures to counterparties operating in the same geographic region (Directive 211).

The general requirements pertaining to risk management in Directive 339 (see CP-7) appear to be implicitly relevant to country risk, too. They relate to the need for a bank to invest resources in understanding, evaluating, and quantifying the full range of risk exposures, to base risk management on a comprehensive management information system and to anchor risk management in clear working procedures. Furthermore, a bank's risk management system must encompass its branches in Israel and abroad and take account of the risk exposures of its subsidiaries in Israel and abroad.

Also, BSD rules on capital adequacy take account of country risk in the risk-weights that are assigned to the various risks.

Another aspect of this risk is treated by means of the supervisory requirements relating to a bank's activity via subsidiaries and branches abroad. BSD requires a bank to have a policy, approved by the board of directors, which includes reference to the deployment abroad, its objectives, and its contribution to the banking group. The board must determine the risk appetite as it pertains to the activities of subsidiaries and branches abroad, at the levels of the individual organ and total activity, and must set limits on the subsidiaries' and branches' activities. BSD also requires this limit to reflect the concentration of exposure in a given geographic area, an individual country, and an individual entity, and insists that the limit be fully integrated into the bank's policy on exposure to country risks and to the limits that it has set in this respect (Supervisor's letter, August 2008).

Reporting to the public and to BSD directives, which correspond to the accepted U.S. reporting provisions, should help banking corporations to identify, summarize, and measure each individual country's country risk and transfer risk.

In its off-site surveillance, BSD examines and monitors the way banks manage this risk (on the basis of "exposure documents," policies, risk appetite). As part of the ICAAP process, banks are required to present and evaluate their geographic exposure. The geographic exposure that banks create due to their activity via subsidiaries and branches abroad is also checked.

In on-site examinations, BSD may remark about a heightened risk level that borrowers who are active in certain countries should be assigned due to their geographic location. It may even require banks to enhance the policy and risk management procedures regarding such exposures. An example of supervisory intervention in this field is BSD (January 1, 2009), which instructed the banks to make separate reference in their credit policies to borrowers whose main activity takes place in countries that have special risk characteristics and/or who have debt that is to be paid back on the basis of assets located in such countries. 
EC-2: The Supervisor confirms that banks have information systems, risk management systems and internal control systems that accurately monitor and report country exposures and ensure adherence to established country exposure limits.

Exposures to risk must be reported to management and the board of directors as part of the general requirements for periodic reporting on risks (Directives 301 and 339). But there are no specific requirements relating to country risk. Yet, the extensive set of reports to BSD and the public on this matter (see EC4) aims to assure measurement and reporting of such country risk.

Banks are required through the ICAAP-SREP proceedings to manage credit exposures in accordance with the borrower's place of activity.

EC-3: There is supervisory oversight of the setting of appropriate provisions against country risk and transfer risk. There are different international practices which are all acceptable as long as they lead to risk-based results. These include:

- The Supervisor (or some other official authority) decides on appropriate minimum provisioning by setting fixed percentages for exposures to each country.

- The Supervisor (or some other official authority) sets percentage ranges for each country, and the banks may decide, within these ranges, which provisioning to apply for the individual exposures.

The bank itself (or some other body such as the national bankers' association) sets percentages or guidelines or even decides for each individual loan on the appropriate provisioning. The provisioning will then be judged by the external auditor and/or by the Supervisor.

Effective January 2011, in accordance with Reporting to Public directives, every bank has been making, at its discretion, individual credit loss provisions on account of exposures that are examined on an individual basis and are found to be problematic. This includes exposures of foreign banks and of foreign countries. Also, effective January 2011, a bank must, at its discretion, make collective credit loss provisions that take into account, among other things, of indebtedness of less-developed countries and economic, national, political, and environmental characteristics and trends. The requirement to make a supplemental provision, including one on account of undue indebtedness of less-developed countries, has become a minimum floor for the calculation of the collective allowance.

Following on-site examinations on the banks' treatment of the value of collateral and credit to companies that are active in certain countries, the banks received comments about deficiencies in classification and lack of provisions. BSD notably instructed the banks to set especially conservative haircuts in the methodology of credit classification and credit-loss provisioning.

As part of their ICAAP process, banks are required to make a capital charge against risk in the credit portfolio, including country risk where necessary.

EC-4: The Supervisor obtains and reviews sufficient information on a timely basis on the country risk and transfer risk of individual banks.

BSD has a wide range of reporting requirements on country risk exposures that allow analysis and evaluation of the risk in an individual bank and the banking system as a whole: 


\begin{tabular}{|c|c|}
\hline & $\begin{array}{l}\text { - Quarterly Reporting to the Public and to BSD about exposure to foreign countries; } \\
\text { - Quarterly Reporting to the Public and to BSD about operating segments and } \\
\text { geographic regions; } \\
\text { - Quarterly Reporting to the Public and to BSD about exposure to foreign financial } \\
\text { institutions; and } \\
\text { - Quarterly/annual reporting to BSD on activity of the bank's offices abroad } \\
\text { Recently, compulsory reporting to BSD and to the public by banks was expanded to } \\
\text { include monthly/current reporting where necessary. }\end{array}$ \\
\hline Assessment & Compliant \\
\hline Comments & $\begin{array}{l}\text { Israeli regulation entails very demanding requirements in terms of risk measurement } \\
\text { and reporting. While it allows banks to set by themselves the provisions assigned to } \\
\text { country risk, these provisions remain under close scrutiny of BSD, which appears to } \\
\text { be very proactive in this field. }\end{array}$ \\
\hline Principle 13. & $\begin{array}{l}\text { Market risk. Supervisors must be satisfied that banks have in place policies and } \\
\text { processes that accurately identify, measure, monitor and control market risks; } \\
\text { supervisors should have powers to impose specific limits and/or a specific capital } \\
\text { charge on market risk exposures, if warranted. }\end{array}$ \\
\hline tion & $\begin{array}{l}\text { BSD directives define market risk as the risk of losses in on-balance-sheet and off- } \\
\text { balance-sheet positions arising from changes in the fair value of a financial instrument } \\
\text { due to changes in market conditions. For regulatory capital purposes, they set rules } \\
\text { for the estimation of market risks pertaining to interest rate-related instruments and } \\
\text { equities in the trading book and foreign exchange risk throughout the banking } \\
\text { corporation. } \\
\text { It should be noted that trading activity is modest in volume and traditional in its } \\
\text { characteristics (no trading in securitization or writing credit derivatives, low volume of } \\
\text { market making activities and equities trading). } \\
\text { EC-1: The Supervisor determines that a bank has suitable policies and processes that } \\
\text { clearly articulate roles and responsibilities related to the identification, measuring, } \\
\text { monitoring and control of market risk. The Supervisor is satisfied that policies and } \\
\text { processes are adhered to in practice and are subject to appropriate Board and senior } \\
\text { management oversight. } \\
\text { Directives } 301 \text { and 339, which deal with risk management in a general way, establish } \\
\text { guidelines that are relevant in the particular case of market risk, as regards: } \\
\text { - the responsibility of the board of directors for outlining the corporation's overall } \\
\quad \text { strategy, approving policies, and supervising management's actions; } \\
\text { the basic principles for the management and control of risks; } \\
\text { - the requirements for models validation (see EC-4.); and } \\
\text { the conduct of stress testing (see CP-7 and EC-4.). } \\
\text { Directive } 208 \text { sets out the guidelines on risk measurement for capital adequacy } \\
\text { purposes, in accordance with the Standardized Approach of Basel II (Directive 208). } \\
\text { BSD has not yet published comprehensive rules for internal models. } \\
\text { As part of their ICAAP, banks are required to conduct a comprehensive risk } \\
\text { assessment that includes market risks (Directive } 211 \text { ). } \\
\text { The Reporting-to-Public Directives require quarterly quantitative and qualitative } \\
\text { comprehensive reporting on exposures to market risks exposures. }\end{array}$ \\
\hline
\end{tabular}


In the course of off-site and on-site examinations, BSD reviews policy documents and relevant procedures, aspects of corporate governance. Through the SREP, BSD examines market risks by means of risk cards, including assessments of the functioning of the board of directors and management, the risk-management policy, and structured risk (see CP-19). There is, however, no distinction between banking and trading books in evaluating this risk in this context].

In 2010, On-Site examination unit conducted a review of all the banks' activity in exotic options and other complex derivatives (that are not "plain vanilla").

EC-2: The Supervisor determines that the bank has set market risk limits that are commensurate with the institution's size and complexity and that reflect all material market risks. Limits should be approved by the Board or senior management. The Supervisor confirms that any limits (either internal or imposed by the Supervisor) are adhered to.

Directives 301 and 339 require the board to discuss and approve policy of exposure to various risks, including market risks. This includes not only the setting of limits, but also the approval of any new activity, following an assessment of the risks involved therein and of the mechanisms which will be used to manage, measure, and control them.

Directives 339 and 301 require the management to report to the board of directors on compliance with the limits or material deviation from the limits.

BSD uses off-site tools to examine, on an ongoing basis, compliance with limits set by the board of directors, including the commensuration of the limits with the volume and complexity of the banking corporation's activity and risk appetite, including their efficacy. Reports to the board of directors about compliance with the limits and infringements of these limits are examined.

EC-3: The Supervisor is satisfied that there are systems and controls in place to ensure that all transactions are captured on a timely basis, and that the banks' marked to market positions are revalued frequently, using reliable and prudent market data (or, in the absence of market prices, internal or industry-accepted models). The Supervisor requires banks to establish and maintain policies and processes for considering valuation adjustments/reserves for positions that otherwise cannot be prudently valued, including concentrated, less liquid, and stale positions.

Directive 339 states that, beyond materiality thresholds, market risks arising from overall banking activities must be managed by means of a comprehensive system. The Supervisor sent a letter to banks in which he required them to abstain from performing a transaction if they do not know how to record it in their books according to the accounting standards (REG 106).

Directive 208, relating to measurement and capital requirements for market risks, determines that a banking corporation must have clear trading book eligibility policies and procedures. To this end, the directive includes a minimum list of main points to be addressed, such as assessing the extent to which an exposure can be marked-tomarket daily by reference to an active, liquid two-way market, and the extent to which a banking corporation can and is required to generate valuations for the exposure that can be validated externally in a consistent manner.

The positions eligible to receive trading book capital treatment are subjected to specific valuation requirements. Banking corporations must set up and maintain appropriate systems and controls, including documented policies and procedures for 
the valuation process as well as clear and independent reporting lines for the desk in charge of the valuation process. They must perform independent price verification and implement valuations adjustments or reserves.

The fair-value estimates are included in the annual and quarterly financial reports to the public and to BSD. The Reporting-to-the Public Directives include detailed instructions concerning the definition of fair value and the application of valuation techniques.

In its on-site examinations, BSD examines the banks' market-risk management systems and the policies and procedures aimed at ensuring the reliability of the trading book positions valuation.

EC-4: The Supervisor determines that banks perform scenario analysis, stress testing and contingency planning, as appropriate and periodic validation or testing of the systems used to measure market risk. The Supervisor confirms that the approaches are integrated into risk-management policies and processes, and results are taken into account in the bank's risk-taking strategy.

Directive 339 requires banks exceeding materiality thresholds to include in their market-risk management systems an ongoing measurement of their market risks via VaR estimates and stress-scenario analyses. Directive 211 sets out the same requirements for the assessment of internal capital adequacy, adding that sophisticated banks should include estimates of concentration risk and assessment of illiquidity under stress scenarios. The latter directive also states that a banking corporation's VaR model should integrate into the overall internal capital assessment and withstand rigorous validation proceedings on an ongoing basis. The VaR model should be complemented by stress tests and additional risk-management techniques, to prove that the bank has enough capital not only to meet minimum capital requirements but also to withstand severe but plausible market shocks. The VaR methodologies and stress tests should evolve to accommodate the changes, if any, in instruments and trading strategies.

Directive 339 also requires banks to establish a risk-control function that is independent of those in charge of managing and trading the various instruments and that reports directly to the CEO. BSD has instructed the banks to properly validate the models in use, inter alia, market risk models, but the BSD does not itself validate the models.

In its on-site examinations, BSD examines whether a bank's market-risk management system includes stress-scenario analysis of market risks, whether the board of directors approved the set of stress scenarios and set limits to them, and whether the scenario outcomes are reported to management on an ongoing basis. In addition, BSD examines whether the independent risk-control unit evaluates and validates the models used and whether it reports the results of its examinations on an ongoing basis.

AC-1: The Supervisor requires that market data used to value trading book positions are verified by a function independent of the lines of business. To the extent that the bank relies on modeling for the purposes of valuation, the bank is required to ensure that the model is independently tested.

Directive 208 requires banks to have a verification of market prices or model inputs performed at least monthly by a unit independent of the dealing room. According to Directive 339, those banks required to manage their market risks according to a VaR model should also have a risk control unit in charge of assessing the adequacy of these models. In December 2008, BSD published guidelines and clarifications about 


\begin{tabular}{|c|c|}
\hline & $\begin{array}{l}\text { internal control of fair value valuation of financial instruments (REG 106). } \\
\text { In its examinations, BSD examines whether the bank specified processes for testing } \\
\text { of the adequacy of the models that it uses, including those used for valuation, and } \\
\text { whether the risk-control function is independent and involved in assessing the } \\
\text { adequacy of the models. }\end{array}$ \\
\hline Assessment & Materially non-compliant \\
\hline Comments & $\begin{array}{l}\text { Prior to the implementation of Basel II, banks were allowed to calculate their capital } \\
\text { requirements in respect of market risks using an internal model upon receiving the } \\
\text { prior written approval of the Supervisor. Yet none of them applied for such an } \\
\text { approval. Since the entry into force of Basel II, the regulatory framework relies on a } \\
\text { two-pronged approach: } \\
\text { - for capital purposes, it requires banks to measure their market risk based only } \\
\text { on the standardized approach; } \\
\text { for risk management purposes, it requires banks to measure, monitor and } \\
\quad \text { manage their market risk exposures based on VaR models, complemented } \\
\text { as appropriate by stress tests and additional risk-management techniques. } \\
\text { Indeed, as may have been the case before the implementation of Basel II, a lack of } \\
\text { experienced resources does not seem to allow BSD to sufficiently assess the banks' } \\
\text { exposures to market risks. The scarcity of resources assigned to market risk in the on- } \\
\text { site examination largely explains the low number of examinations performed in this } \\
\text { field over the last five years, including at some of the very largest banks. It also helps } \\
\text { to explain the insufficient depth of such on-site examinations, which focus on } \\
\text { governance and risk management issues, but do not reveal a significant independent } \\
\text { assessment of the adequacy of trading book eligibility policies, the reliability of data } \\
\text { processing systems, the adequacy of the models' design and implementation, and the } \\
\text { prudence of valuation methodologies. } \\
\text { Furthermore, the off-site assessment of a bank's exposure to market risks for Pillar II } \\
\text { purposes, whether within the framework of the Risk-Based Supervision (risk cards) or } \\
\text { that of the SREP, is biased by the amalgamation of the interest-rate risks arising from } \\
\text { positions in both the trading and the banking books. In consequence, the measures } \\
\text { used for the purpose of assessing a bank's market risk profile may be unduly offset } \\
\text { against each other (see CP 16). }\end{array}$ \\
\hline Principle 14. & $\begin{array}{l}\text { Liquidity risk. Supervisors must be satisfied that banks have a liquidity management } \\
\text { strategy that takes into account the risk profile of the institution, with prudent policies } \\
\text { and processes to identify, measure, monitor and control liquidity risk, and to manage } \\
\text { liquidity on a day-to-day basis. Supervisors require banks to have contingency plans } \\
\text { for handling liquidity problems. }\end{array}$ \\
\hline Description & $\begin{array}{l}\text { Directive } 342 \text { covers mainly qualitative aspects of risk management, such as the } \\
\text { requirements of having policies, surveillance, controls and contingency plan for } \\
\text { handling liquidity problems in place, and covers quantitative aspects by requiring a } \\
\text { minimum liquidity ratio based on the banks' internal models } \\
\text { BSD regularly examines banks' liquidity risk and the quality of their management of } \\
\text { this risk in off-site processes—ongoing surveillance, SREP, and review of ICAAP } \\
\text { reports - and in on-site examinations by a dedicated market and liquidity risk } \\
\text { examination unit that follows an internal manual of examinations relating to the } \\
\text { management of liquidity risks. } \\
\text { EC-1: The Supervisor sets liquidity guidelines for banks. These guidelines take into } \\
\text { consideration undrawn commitments and other off-balance sheet liabilities, as well as } \\
\text { existing on-balance sheet liabilities. }\end{array}$ \\
\hline
\end{tabular}


Directive 342 requires banks to have in place a liquidity-risk management policy that is approved by the board of directors, as well as appropriate information system, reporting, measurement, control, and auditing of the matter.

Banks must also maintain a mechanism for the on-going measurement and control of their liquidity position on a daily basis, on a solo basis (including overseas branches), that shall be performed by calculating the liquidity mismatch according to repayment periods and the ratio of the liquid assets to liabilities for a repayment period of up to one month. The latter ratio, which shall be no lower than 1 , is calculated either by means of a well based internal model, or according to standardized provisions set in the directive. Though not formally, BSD instructed banks to take into account the solo calculation liquidity needs resulting from subsidiaries (BSD is in the process of amending Directive 342 to strengthen the requirements regarding, inter alia, liquidity on a group basis, liquidity for shorter and longer periods.)

For the purpose of calculating this ratio, liquid assets are defined as assets that can be converted into cash quickly, simply and at a reasonable cost or that can be paid when the management anticipates a need for additional liquidity. Such liquid assets include cash and, provided they mature in less than one month, Treasury deposits, deposits with the Bank of Israel, marketable government bonds and deposits with banks, plus a proportion of other marketable government bonds. Banks that use an internal model can also include assets that, according to their model, represent a reliable source for a cash receipt.

Liabilities for repayment up to one month are assessed according to their contractual residual maturity. Banks using an internal model can increase or decrease the balance of these liabilities for a repayment period of up to one month by the level of repayments predicted by the model.

Banks are required to submit monthly reports to BSD on liquidity risk, including data on - and off-balance-sheet items. They may be required to submit liquidity reports more frequently in sensitive times.

However, these reports are on a solo basis. In analyzing reports on a solo basis, the BSD deducts the deposits with the banks which are part of the banking group, that are for a shorter term than one month, from the liquid assets and from liabilities in order to calculate the liquidity ratio. This adjustment is helpful in some regards by avoiding double counting, but does not yield a group liquidity ratio.

EC-2: The Supervisor confirms that banks have a liquidity management strategy, as well as policies and processes for managing liquidity risk, which have been approved by the Board. The Supervisor also confirms that the Board has an oversight role in ensuring that policies and processes for risk-taking are developed to monitor, control and limit liquidity risk, and that management effectively implements such policies and processes.

Three directives deal with internal governance and risk management in a general way that makes them relevant in the field of liquidity risk as well.

Directive 301 holds the board of directors responsible for outlining the corporation's overall strategy, approving policies, and supervising management actions.

Directive 339 mandates the specification of basic principles for the management and control of risks (including liquidity risk). The principles include adequate involvement in and thorough understanding of risk management on the part of the board of directors; management of risks by means of a Chief Risk Officer (CRO) who is a member of management (in the amendment to the directive, as mentioned in CP7-CRO); and having tools in place for the assessment and measurement of risks and setting ways 
of supervising and controlling them.

Directive 211 specifies that, as part of the capital adequacy assessment, every banking corporation must have appropriate systems for the measurement, monitoring, and control of liquidity risk and it must assess its capital adequacy in view of its liquidity profile and the liquidity of the markets in which it operates.

In addition to these cross-cutting directives, Directive 342 deals with the management of liquidity risk specifically and sets forth the following principles and requirements:

- A bank must have in place a comprehensive risk management policy, approved by the board of directors;

- The board of directors is responsible for the supervision of risk management, including at the group level;

- A bank must have an appropriate information system for control, measurement, and reporting on liquidity position, including overall liquidity position in foreign currency and liquidity position in the main currencies in which the bank does business;

- A bank must maintain a mechanism for ongoing measurement and control of liquidity position;

- A bank must set limits on its liquidity estimates (as detailed in the directive), including overall liquidity position in foreign currency.

As with other risks, BSD uses both off-site and on-site tools to confirm that the banks are abiding by the aforementioned directives.

Within the SREP framework, BSD evaluates liquidity risk by means of risk cards (see CP-19.) This evaluation covers, among other things, attention to risk management policies, procedures, and processes, including supervision and control by the board of directors.

EC-3: The Supervisor determines that a bank's senior management has defined (or established) appropriate policies and processes to monitor, control and limit liquidity risk; implements effectively such policies and processes; and understands the nature and level of liquidity risk being taken by the bank.

A bank's management must satisfy the regulatory requirements mentioned in EC-1 and EC-2 in regard to management, measurement, oversight, and control of this risk, including reporting to the board of directors. BSD uses both on-site and off-site proceedings to check compliance with these requirements.

EC-4: The Supervisor requires banks to establish policies and processes for the ongoing measurement and monitoring of net funding requirements. The policies and processes include considering how other risks (e.g., credit, market and operational risk) may impact the bank's overall liquidity strategy, and require an analysis of funding requirements under alternative scenarios, diversification of funding sources, a review of concentration limits, stress testing, and a frequent review of underlying assumptions to determine that they continue to be valid.

Directive 342 includes various qualitative requirements for ongoing measurement and monitoring of funding needs, scenario analysis, diversification of funding sources, limiting concentration of sources, and examining assumptions. In particular, banks must hold periodic discussions about funding sources and funding needs and must make decisions about the composition, characteristics, and diversity of their funding sources. They must also test their forecasted cash flows under various scenarios bank specific scenarios and systemic scenarios and in reference to past experience. They must set limits on the structure of their funding sources that refer, among other 
things, to depositor concentration, depositor types, and repayment period and periodically examine the assumptions that they use to manage liquidity. When determining its overall liquidity policy, the bank must take into account the possible implications of other risks to liquidity, including credit risks, market risks, and operational risks.

BSD has augmented these requirements with additional guidelines: banks must validate their risk-measurement models (Directive 339) and follow a specific guidance for the validation of models and the framework for stress-testing (see details in CP-7, EC-1 and EC-6).

BSD uses on-site and off-site tools to examine the quality of the banks' risk management. In particular, the following parameters are examined: functioning of the organs of corporate governance, internal limits, models, information systems, control, and reporting on the position of liquidity, early-warning mechanisms for deviations from limits or deterioration of liquidity position, stress scenarios, and the composition, characteristics, and diversity of funding sources.

EC-5: The Supervisor obtains sufficient information to identify those institutions carrying out significant foreign currency liquidity transformation. Where a bank or banking group's foreign currency business, either directly, or indirectly through lending in foreign exchange to domestic borrowers, is significant, or where a particular currency in which the bank has material exposure is experiencing problems, the Supervisor requires the bank to undertake separate analysis of its strategy for each currency individually and, where appropriate, set and regularly review limits on the size of its cash flow mismatches for foreign currencies in aggregate and for each significant individual currency.

Directive 342 addresses liquidity positions in domestic and aggregate foreign currency, and main currencies in which the bank does business. Banks are required to have in place a system for management, control, and monitor of the overall state of liquidity in aggregate foreign currency and in main currencies in which they do business. Also, banks must perform an assessment of their foreign currency liquidity needs and set internal limits on total foreign currency liquidity. However, unlike liquidity in shekels, BSD does not currently set explicit limits in respect of foreign currency liquidity. In practice, banks calculate the required liquidity ratio in shekels and foreign currency separately and are required to report it to BSD. (the BSD intends to anchor the requirement to comply with liquidity ratios in both currency groups in the amendment to Directive 342.)

The Reporting to BSD Regulation requires banks to submit a monthly report to BSD with information about future expected cash flows, off-balance-sheet items parsed by terms to maturity, liquidity ratios according to the reporting bank's internal model-in domestic currency, in foreign currency, and in both sectors-and information about deposits: deposit to the public parsed by size and the twenty largest depositors by terms to maturity.

The Reporting to the Public Regulations requires, among others, banks to report the state of short-term liquidity (up to 12 months) and long-term liquidity. Banks must also report assets and liabilities (including derivatives) by indexation bases and terms to maturity (future expected cash flows). The indexation bases are non-indexed domestic currency, indexed domestic currency, domestic activity in foreign currency, and foreign activity in foreign currency.

In addition to these requirements, banks must report immediately any material breach of limits and any other material liquidity problem to the Supervisor of Banks (directive 342). 
BSD examines whether the bank has an adequate information system for measurement, control, and monitoring of the overall positions of foreign-currency liquidity on a daily basis. BSD also examines whether the bank performs ongoing assessment of its foreign-currency liquidity risk, whether it has limits on foreigncurrency liquidity, and whether it examines its position of foreign-currency liquidity under different scenarios.

EC-6: The Supervisor determines that banks have contingency plans in place for handling liquidity problems, including informing the Supervisor.

Directive 342 requires banks to have a contingency plan for dealing with liquidity problems. The contingency plan must include specification of the process to be used in coping with problems, funding sources for coverage of a liquidity gap, and the executive team that is responsible for dealing with a liquidity crisis. The directive also requires banks to advise BSD immediately about a material breach of limits or the occurrence of some other material liquidity problem.

In its on-going supervision, BSD examines the existence of contingency plans for liquidity crises that specify the process to be used in coping with liquidity problems.

AC-1: The Supervisor determines that, where a bank conducts its business in multiple currencies, foreign currency liquidity strategy is separately stress-tested, and the results of such tests are a factor in determining the appropriateness of mismatches.

Directive 342 requires banks to have a system in place for measuring, controlling and monitoring foreign-currency liquidity in the aggregate and by the main currencies in which they do business, and to set limits on the amount of foreign liquidity needs. The bank's system must include, among other things, estimation of the state of liquidity, management of sources, preparedness for a liquidity crisis, and stress testing.

AC-2: The Supervisor confirms that banks periodically review their efforts to establish and maintain relationships with liability holders, maintain the diversification of liabilities, and aim to ensure their capacity to sell asset.

Directive 342 requires banks to periodically review the composition and concentration of their funding sources (see EC-4). Following these reviews, a bank's management must make decisions as to the composition, characteristics and diversification of its funding, with the view to diversifying the liabilities, after allowing for the potential changes in the market attitude towards the bank, in case of changes in its rating, income and profitability.

Directive 342 also requires banks to hold enough liquid assets, i.e., maturing or sellable assets with which cash can reliably be raised. Examination of the types of assets that qualify as liquid assets in the bank's internal model is an integral part of defining and validating the model.

Assessment Largely compliant

Comments

The regulatory framework allows BSD to require sound liquidity risk management policies and processes. Further, based on detailed and frequent reporting, BSD performs intrusive and on-going oversight of banks' exposure to such risk.

However, this oversight is based on information that is calculated on a solo basis only. While care is taken to properly cancel double-counting of liquidity assets, the addingup of solo reportings received from the various entities within the banking corporations should not be viewed as an adequate substitute for an effective consolidated approach to liquidity risk. The regulatory limits (unlike the reports) apply only to overall liquidity, without breakdown by major currencies, and only over a one-month 
horizon.

Furthermore, BSD has not been able to check the quality of data feeds and processing, as evidenced by the very low number of on-site examinations conducted on liquidity risk, even in some of the largest banks. At most, BSD has been led to pinpoint a very basic issue to the industry, i.e. the need to include off-balance sheet liabilities in the scope of reporting.

The reliability of the reported information is all the more questionable since all the banks report on the basis of their internal models, whose results are very much driven by the underlying assumptions. This results in a definition of liquid assets that may not necessarily be adequate. Also, the internal treatment of assets and liabilities which have no contractual maturities or are subject to behavioral optionality may thus significantly impair the outcome of the results on which BSD is checking the banks' compliance with the regulatory limits.

Against this background, BSD should devote more resources to checking the quality of the information which not only supports its own oversight but also is said to drive the bank's management of liquidity risk.

Principle 15. Operational risk. Supervisors must be satisfied that banks have in place risk management policies and processes to identify, assess, monitor and control/mitigate operational risk. These policies and processes should be commensurate with the size and complexity of the bank.

Description

EC-1: The Supervisor requires individual banks to have in place risk management policies and processes to identify, assess, monitor and mitigate operational risk. These policies and processes are adequate for the size and complexity of the bank's operations, and the Supervisor confirms that they are periodically adjusted in the light of the bank's changing risk profile and external market developments.

The directives on risk management, as specified in CP-7, apply to operational risk as well. Within this construct, a bank must have a risk-management policy, approved by the board of directors, and processes for the identification, assessment, monitoring, and mitigation of operational risk. The risk policy and the risk-management system include the bank, its subsidiaries, and its branches abroad, as required with regard to the full range of risks.

Since the adoption of Basel II Framework, Directive 206 sets out guidelines for the measurement of operational risk for capital adequacy purposes and qualitative provisions concerning the manner in which the risk should be managed. All banks in the Israeli banking system with one exception calculate capital by using the Basic Indicator Approach (BIA). But banks must satisfy the February 2003 Basel Committee guidelines concerning Sound Practices for the Management and Supervision of Operational Risk, irrespective of the approach used for capital purposes. (BSD is in the process of issuing a new directive regarding operational risk, based on the Basel Committee June 2011 document. The directive will serve as a framework for operational risk management).

Directive 211 requires banks to develop, as part of their ICAAP, a framework for management of operational risk and to estimate capital adequacy in accordance with this directive and with Directive 206. The framework must reflect the bank's appetite for and tolerance of operational risk and include policies describing the bank's approach toward the identification, assessment, monitoring, and control/mitigation of this risk.

Other BSD directives cover various aspects of operational risk. For example, Directive 309 and the Reporting to Public Directives require a bank's management to have effective controls for financial reporting, to adjust the controls to the nature of the 
bank's activity, to update the internal controls every year and check their effectiveness at the same frequency. These directives also state that an external auditor must verify the effectiveness of the internal control of financial reporting every year. Directive 357 sets out guidelines for sound management of the information technology (IT) system, Directive 360 on the topic of rotation and uninterrupted leave.

BSD uses ongoing supervision techniques, including on-site examinations and off-site monitoring, to evaluate the adequacy of the operational risk management policies and processes. In addition, since a significant portion of operational risk control is covered by an evaluation of the effectiveness of the bank's internal controls on financial reporting, and since the external auditor performs an annual assessment of the controls, BSD receives each year detailed reports from the external auditor that review faults in internal control over financial reporting and how they are rectified.

EC-2: The Supervisor requires that banks' strategies, policies and processes for the management of operational risk have been approved and are periodically reviewed by the Board. The Supervisor also requires that the Board oversees management in ensuring that these policies and processes are implemented effectively.

Directive 301 determines that the board of directors shall discuss, decide, and issue instructions, on the overall strategy and policy and overall risk management policy, including approval of policy and the method of risk management for each of the bank's various risks (credit risks, market risks, operational risks, including IT, liquidity risks, legal risks, etc.), and shall supervise the actions of management and their compliance with the board's policy. The risk policy should cover all its subsidiaries and overseas branches.

With regard to IT management, Directive 357 sets out a specific requirement that a banking corporation's board of directors should hold a periodic discussion and specify an IT management policy, that management hold an annual discussion and make decisions on the implementation and budgeting of the IT management policy and on the implementation of IT security policy.

According to the Reporting to Public Regulations as they relate to financial reporting (Directive 309), the board of directors and management must affirm, each year, the existence of effective and comprehensive controls that include operational risk (see CP-22).

In the course of on-site and off-site examination, BSD reviews a bank's operational risk related strategies, policies, and processes in order to verify that they are current, reflective of the nature of the organization, and formally approved by the board.

EC-3: The Supervisor is satisfied that the approved strategy and significant policies and processes for operational risk are implemented effectively by management.

BSD reviews and evaluates external and internal audit reports and selected management reports to verify that management has effectively implemented boardapproved operational risk management strategies, policies, and procedures. In addition, BSD performs selected off-site/on-site examination of the effectiveness of operational risk management and control policies and processes.

EC-4: The Supervisor reviews the quality and comprehensiveness of the bank's business resumption and contingency plans to satisfy itself that the bank is able to operate as a going concern and minimize losses, including those that may arise from disturbances to payment and settlement systems, in the event of severe business disruption. 
BSD regulates business continuity and preparedness for emergency both generally and in terms of IT, given its status as part of the National Emergency Management Authority and the definition of the banks as "essential enterprises" (Emergency Labor Service Law, 5727-1967).

It has only recently issued a draft directive concerning business continuity management. Currently, the reference to emergencies and business continuity is thus still anchored in the Supervisor's letter of October 2002 PCBB 357 refers to backup and recovery arrangements.

BSD has appointed a staff member in charge of the banking system's business continuity, who centralizes treatment of the matter by issuing guidelines, verifying their assimilation, and obtaining reports from the banks on the topic; he also interfaces with other national and regulatory authorities to enhance the financial system's preparedness for sundry emergencies.

In conjunction with the BOl's Payment and Settlement Systems Division, BSD sent the banks instructions relating to the business continuity plan of the Paper-Based Clearinghouse (Letter of February 2011). Additionally, BSD and the banks took part in a national emergency exercise.

Regarding IT aspects, BSD has performed risk-focused on-site examinations of banks' business resumption and contingency plans. The full coverage of the banking system was done by a comprehensive questionnaire issued in 2004, sent to the internal auditors which were required to conduct the process. After reviewing the banks' detailed responses, BSD conducted dialogues with the banks regarding key findings and required corrective actions.

Additionally, under certain circumstances, the business resumption and contingency plans of banks and holding companies, individually by organization and/or horizontally across groups of banks and holding companies, are the subject of both on-site and off-site supervision.

BSD is not responsible for oversight of national settlement and payment systems.

EC-5: The Supervisor determines that banks have established appropriate information technology policies and processes that address areas such as information security and system development, and have made investments in information technology commensurate with the size and complexity of operations.

Directive 357, concerning IT management, very precisely addresses a range of matters related mainly to aspects of management and control of IT risks, electronic banking, on-line banking, information security, bank reports, foreign banks and system continuity. Beyond the governance of these risks, the directive determines that a bank must establish and update detailed procedures for every stage and for every process that deals with the management, operation, security, backup, continuity and control of IT and shall carry out appropriate control of the performance thereof.

BSD covers the IT area mainly via on-site inspections, carried out by the unit specialized in operational risk, composed of seven auditors. This unit has developed a questionnaire based on best practices in IT governance and a toolkit that facilitates the assessment of gaps in this area. BSD also monitors the IT field in off-site examinations, by studying the minutes of board of directors' discussions and internal or external audit reports (see EC-1)

EC-6: The Supervisor requires that appropriate reporting mechanisms are in place to keep the Supervisor apprised of developments affecting operational risk at banks in 
their jurisdictions.

In the context of their ICAAP, banks are expected to describe their policies, management tools, risk levels, and methodology for capital assignment on account of operational risk. According to Directive 303 , they must also transmit a copy of the annual long form report and complementary report of the external auditor, which include a detailed review of all significant faults in internal control over financial reporting. According to the Reporting to Public directives, banks must make quarterly disclosure of any change during the quarter that had, or is expected to have, a material effect on the internal control over financial reporting.

Reporting to BSD directives include compulsory reporting of exceptional events, e.g. immediate reporting of embezzlement and fraud by employees and officers, any loss that exceeds 1 percent of capital due to an individual action or transaction (Directive 301), and any other material event. Banks must also report to BSD about IT events (Directive 357). On the other hand, while banks have been encouraged to collect operational loss data since the implementation of Basel II, they are not required to report these data to BSD.

EC-7: The Supervisor confirms that legal risk is incorporated into the operational risk management processes of the bank.

Directive 206 defines "operational risk" as "the risk of loss resulting from inadequate or failed internal processes, people and systems or from external events" (stating explicitly that this includes legal risk but excludes strategic and reputational risk). While Directive 206 addresses only operational risk for capital adequacy purposes, it provides a benchmark for the management of operational risk. Accordingly, legal risk has been implicitly (although not explicitly) considered as a component of operational risk in every respect of BSD standards.

EC-8: The Supervisor determines that banks have established appropriate policies and processes to assess, manage and monitor outsourced activities. The outsourcing risk management program should cover:

- conducting appropriate due diligence for selecting potential service providers;

- structuring the outsourcing arrangement;

- managing and monitoring the risks associated with the outsourcing arrangement;

- ensuring an effective control environment; and

- establishing viable contingency planning.

Outsourcing policies and processes should require the institution to have comprehensive contracts and/or service level agreements with a clear allocation of responsibilities between the outsourcing provider and the bank.

At present, BSD has no general directive that deals with outsourcing. This area of activity is covered only in respect of IT outsourcing (Directive 357). Such outsourcing requires the Supervisor's prior consent in some specific cases. Where outsourcing is significant, a bank shall ascertain the service provider's reliability and economic viability and examine in advance the suitability of its qualifications and ability to perform the assignments. Outsourcing is covered also by a new Directive 355 on Business Continuity Management.

BSD examines specific aspects of the functioning of provider's significant services in respect of the management of IT-related risk.

AC-1: The Supervisor determines that the risk management policies and processes 


\begin{tabular}{|c|c|}
\hline & $\begin{array}{l}\text { address the major aspects of operational risk, including an appropriate operational risk } \\
\text { framework that is applied on a group-wide basis. The policies and processes should } \\
\text { include additional risks prevalent in certain operationally intensive businesses, such } \\
\text { as custody and correspondent banking, and should cover periods when operational } \\
\text { risk could increase. } \\
\text { BSD's requirements concerning the existence of risk management policies and } \\
\text { systems against the risk apply to banking corporations and their subsidiaries and } \\
\text { branches abroad. Also the declaration on the effectiveness of internal control over } \\
\text { financial reporting and the external auditor's opinion are expressed on the group-wide } \\
\text { basis. } \\
\text { No specific requirements are set out in respect of operationally intensive businesses, } \\
\text { such as correspondent banking. Custody activity is covered by Directive 461]. }\end{array}$ \\
\hline Assessment & Largely compliant \\
\hline Comments & $\begin{array}{l}\text { Aside from the capital adequacy assessment, the requirements of relevance for the } \\
\text { management of operational risk are scattered across a large number of directives, } \\
\text { which fails to provide a comprehensive view of the relevant principles for assessing, } \\
\text { monitoring and managing the risk. } \\
\text { This may even result in some loopholes in terms of requirements which relate to } \\
\text { certain sources of operational risk, such as external frauds, outsourcing of functions } \\
\text { other than IT, and correspondent banking. } \\
\text { The compulsory reporting requirements, currently focused on events, should be } \\
\text { extended to the related material losses, which already have to be tracked internally, } \\
\text { by business line, according to Directive } 206 \text {. } \\
\text { BSD is encouraged to adopt a comprehensive regulation of operational risk } \\
\text { management and to devote more resources to on-site examination in this field. }\end{array}$ \\
\hline Principle 16. & $\begin{array}{l}\text { Interest-rate risk in the banking book. Supervisors must be satisfied that banks } \\
\text { have effective systems in place to identify, measure, monitor and control interest-rate } \\
\text { risk in the banking book, including a well defined strategy that has been approved by } \\
\text { the Board and implemented by senior management; these should be appropriate to } \\
\text { the size and complexity of such risk.. }\end{array}$ \\
\hline Description & $\begin{array}{l}\text { No BSD directives touch the specific issue of interest-rate risk in the banking book, but } \\
\text { Directive } 211 \text { is meant to translate the Basel II Pillar II principles into Israeli regulation. } \\
\text { EC-1: The Supervisor determines that a bank's Board approves, and periodically } \\
\text { reviews, the interest-rate risk strategy and policies and processes for the identification, } \\
\text { measuring, monitoring and control of interest-rate risk. The Supervisor also } \\
\text { determines that management ensures that the interest-rate risk strategy, policies and } \\
\text { processes are developed and implemented. } \\
\text { In terms of management, monitoring, control and reporting, this risk is mainly treated } \\
\text { as part of the comprehensive requirements that banks have to satisfy in regard to } \\
\text { overall risk management. But no requirements have been set out to specifically } \\
\text { address the interest-rate risk related to the banking book only, other than: } \\
\text { 1) two provisions contained in Directive } 211 \text {, whereby banks should, as part of their } \\
\text { ICAAP } \\
\text { - consider interest-rate risk in the banking book as a potentially significant risk } \\
\text { which merits support from capital; } \\
\text { include in their measurement process, all material interest-rate positions of } \\
\text { the banking corporation and consider all relevant repricing and maturity data. } \\
\text { 2) reporting under Public Directives, which require banks to disclose the sensitivity of }\end{array}$ \\
\hline
\end{tabular}


their capital to a 100bp parallel shift in the interest rates applied to their banking book positions.

While it might in some cases receive specific information related to the interest-rate risk in the banking book (as opposed to the trading book), BSD does not make use of it in its risk-based framework (risk cards), or in the context of its SREP.

EC-2: The Supervisor determines that banks have in place comprehensive and appropriate interest-rate risk measurement systems and that any models and assumptions are validated on a regular basis. It confirms that banks' limits reflect the risk strategy of the institution and are understood by and regularly communicated to relevant staff. The Supervisor also confirms that exceptions to established policies, processes and limits should receive the prompt attention of senior management, and the Board where necessary.

The only specific regulatory requirement is that banks include in their measurement process, as part of their ICAAP, all material interest-rate positions of the banking corporation and consider all relevant repricing and maturity data.

In practice, some banks measure their exposure to interest-rate risk on both the trading book and the banking book together; others measure this exposure by breaking down these two books.

In both its on-site and off-site examinations, including in the context of its SREP, BSD generally does not single out the interest-rate risk in the sole banking book when assessing the adequacy of policies, processes and limits.

EC-3: The Supervisor requires that banks periodically perform appropriate stress tests to measure their vulnerability to loss under adverse interest-rate movements.

There is a general requirement in Directive 211 that banks should perform stress tests and sensitivity tests in respect of their risk exposures, one of which is related to the interest-rate risk in the banking book. A requirement to perform stress tests on overall interest-rate risk is included in Directive 339, section 9, but as a component of market risk.

AC-1: The Supervisor has the power to obtain from banks the results of their internal interest-rate risk measurement systems, expressed in terms of the threat to economic value, including using a standardized interest-rate shock on the banking book.

The Supervisor has general power to order banks to hand over any information pertaining to their business (Banking Ordinance, 1941). Directive 211 states that a banking corporation must present the Supervisor with the results of its internal measurement systems in terms of economic value relative to capital, using a standardized interest-rate shock.

Banks must present information about their exposure to interest-rate changes in their annual financial statements (expanded reporting) and quarterly statements. This information includes a table capturing the sensitivity of the bank's capital to a parallel shift of 1 percent in the interest rates.

AC-2: The Supervisor assesses whether the internal capital measurement systems of banks adequately capture the interest-rate risk in the banking book.

According to Directive 211, in respect of the exposure to interest-rate risk in the banking book, banks are required to provide BSD with the results of their internal measurement systems expressed in terms of economic value relative to capital, using 


\begin{tabular}{|c|c|}
\hline & $\begin{array}{l}\text { a standard interest-rate shock. } \\
\text { In practice, however, BSD does not assess the interest rate risk in the banking book } \\
\text { separately from the interest-rate risk in the trading book. } \\
\text { AC-3: The Supervisor requires stress tests to be based on reasonable worst case } \\
\text { scenarios and to capture all material sources of risk, including a breakdown of critical } \\
\text { assumptions. Senior management is required to consider these results when } \\
\text { establishing and reviewing a bank's policies, processes and limits for interest-rate risk. } \\
\text { As a general rule, stress testing should be an integral part of the risk-management } \\
\text { regime so that their results influence decision-making at the appropriate executive } \\
\text { echelons and that they be an input in determining the bank's risk appetite when } \\
\text { setting exposure limits. } \\
\text { BSD requirements with regard to stress testing in respect of interest-rate risk in the } \\
\text { banking book are included in Directive } 211 \text { but, according to the information available } \\
\text { to the assessors, the BSD does not conduct any specific assessment in this area. } \\
\text { AC-4: The Supervisor requires banks to assign responsibility for interest-rate risk } \\
\text { management to individuals, independent of and with reporting lines separate from } \\
\text { those responsible for trading and/or other risk-taking activities. In the absence of an } \\
\text { independent risk-management function that covers interest-rate risk, the Supervisor } \\
\text { requires the bank to ensure that there is a mechanism in place to mitigate a possible } \\
\text { conflict of interest for managers with both risk management and risk-taking } \\
\text { responsibilities. } \\
\text { While directive } 339 \text { requires banks to establish an independent function to control } \\
\text { market risks that will be independent of others responsible for managing and trading in } \\
\text { various instruments, there is no such requirement regarding the management of } \\
\text { interest-rate risk in the sole banking book. }\end{array}$ \\
\hline 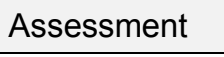 & Non compliant \\
\hline Con & $\begin{array}{l}\text { There are no specific regulatory provisions regarding the treatment of interest-rate risk } \\
\text { in the banking book, except for: } \\
\text { - Directive } 211 \text { which requests the banks to measure such risk in the context of } \\
\text { ICAAP; and } \\
\text { Reporting under Public Directives which require banks to disclose the } \\
\text { sensitivity of their capital to a } 100 \text { bp parallel shift in the interest rates applied } \\
\text { to their banking book positions. } \\
\text { While BSD directives relating to general principles of sound governance and risk } \\
\text { management of market risk (which includes the interest-rate risk on the whole bank's } \\
\text { book) may be considered of relevance in this field, they fail to address the issues } \\
\text { specific to the sole banking book's interest-rate risk. } \\
\text { Against this background, BSD does not perform an assessment of this risk as such. } \\
\text { Furthermore, the inclusion of the banking book positions in the calculation of the } \\
\text { bank's exposure to market risk is likely to substantially undermine the assessment of } \\
\text { the latter by BSD, since it allows these banking book positions to offset trading book } \\
\text { positions for the purpose of assessing the bank's market risk profile in the context of } \\
\text { the SREP. } \\
\text { BSD is strongly recommended to introduce and implement a regulation in this specific } \\
\text { risk area. }\end{array}$ \\
\hline Principle 17. & $\begin{array}{l}\text { Internal control and audit. Supervisors must be satisfied that banks have in place } \\
\text { internal controls that are adequate for the size and complexity of their business. These } \\
\text { should include clear arrangements for delegating authority and responsibility; }\end{array}$ \\
\hline
\end{tabular}




\begin{tabular}{|c|c|}
\hline & $\begin{array}{l}\text { separation of the functions that involve committing the bank, paying away its funds, } \\
\text { and accounting for its assets and liabilities; reconciliation of these processes; } \\
\text { safeguarding the bank's assets; and appropriate independent internal audit and } \\
\text { compliance functions to test adherence to these controls as well as applicable laws } \\
\text { and regulations. }\end{array}$ \\
\hline Description & 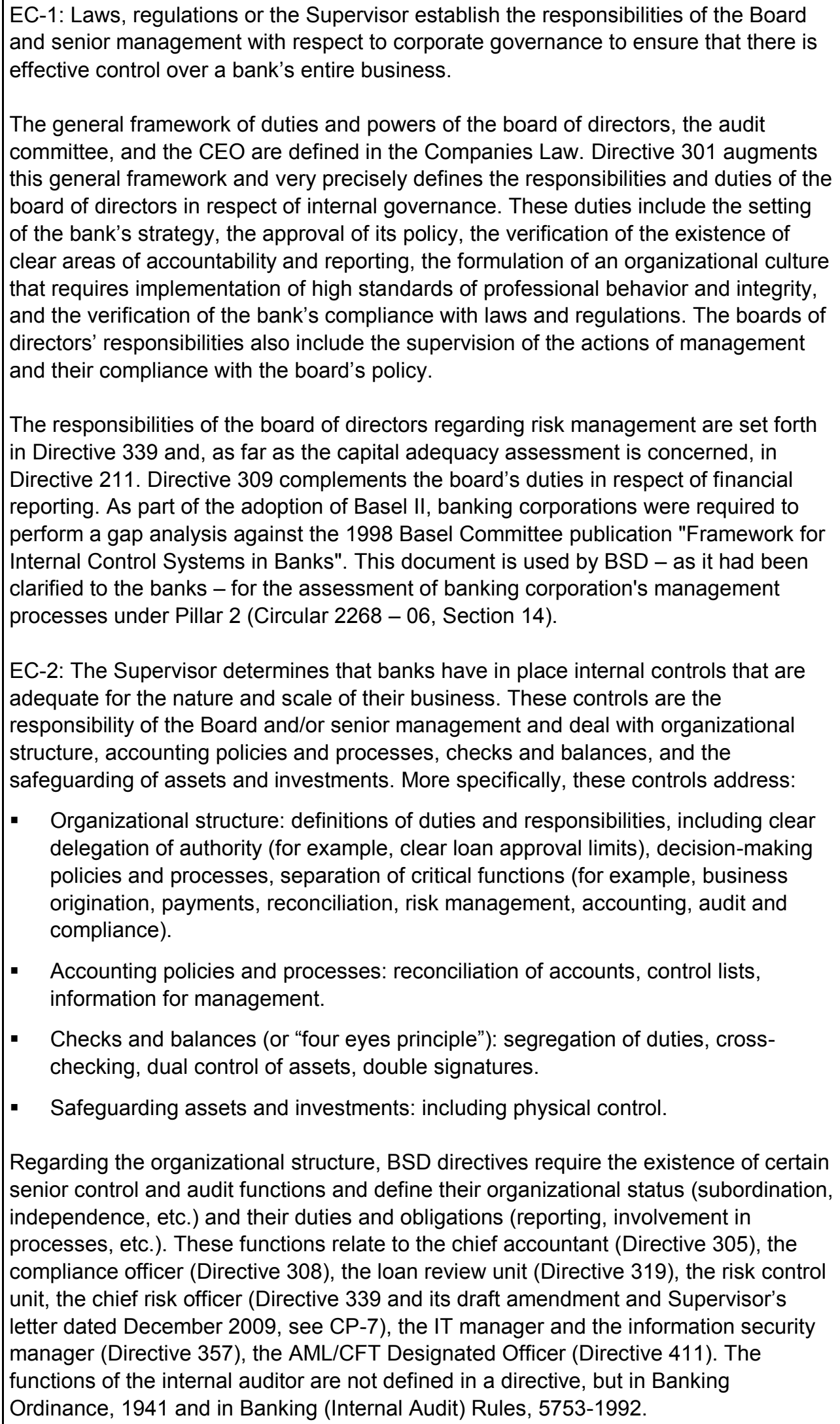 \\
\hline
\end{tabular}


There are presently no requirements for segregating some critical functions, such as business origination, payments and settlements, reconciliation. However, there is a work program in this area.

Regarding financial reporting policies and processes, Directive 309 sets out the controls and procedures relating to disclosure and internal controls over financial reporting.

Requirements regarding the checks and balances to be applied are spread across various directives, which deal with specific activities such as lending policy (Directives 301 and 316), capital market transactions (Directive 322), securities dealing on customers' account (Directive 461), and customer investments in financial assets via portfolio managers (Directive 462). But there is no single directive that lists all requirements relating to internal control.

In its off-site and on-site examinations, BSD verifies compliance with these directives.

EC-3: Laws, regulations or the Supervisor place the responsibility for the control environment on the Board and senior management of the bank. The Supervisor requires that the Board and senior management understand the underlying risks in their business and are committed to a strong control environment.

According to Directive 301 mainly, the board of directors is held responsible for supervising and verifying the banking corporation's efficient use of the work of the audits and control functions, whereas management is responsible for implementing the board's policies and the requirements set forth in BSD's directives.

EC-4: The Supervisor has the power to require changes in the composition of the Board and senior management to address any prudential concerns related to the satisfaction of these criteria.

The Banking Ordinance, 1941 empowers the Supervisor to take measures to prevent the banking corporation from being unable to meet its obligations or from causing harm to its customers or to persons having rights in it. Such measures may be invoked after the Supervisor serves the banking corporation with notice and said corporation fails to correct the defects or prevent their harmful effects. The measures include, but are not limited to, the ability to suspend or limit the powers of a director, manager, or person empowered to sign, and, if the Supervisor finds this insufficient, to terminate said officer's service. Such measures have never been used so far.

Besides, Directive 301 sets prerequisites concerning the composition of the board of directors in order to assure that the board has the requisite characteristics for the performance of its tasks.

BSD sometimes applies informal measures to deal with such deficiencies, if observed in the composition of the board of directors or of management.

In its off-site and on-site examinations, BSD examines the functioning of the board of directors as a whole and of specific directors. It also reviews the functioning of senior management, both collectively and at the level of divisions.

EC-5: The Supervisor determines that there is an appropriate balance in the skills and resources of the back office and control functions relative to the front office/business origination.

There are no specific requirements concerning resources and composition of staff in control and back-office functions in comparison to those of business and front-office 
functions. On the other hand, there are such requirements relating to risk management (Supervisor's letter of December 22, 2009). There is also a supervisory requirement that the remuneration of the functions involved in supervision and control, including financial reporting, be set on the basis of appropriate standards that take into account the importance and sensitivity of the duties that these functions carry out (Supervisor's letter, April 5, 2009).

BSD examines the risk management function comprehensively. The examinations relate, inter alia, to the resources assigned to the $\mathrm{CRO}$ and the risk management functions, the qualifications that their staff must have, and their remuneration.

EC-6: The Supervisor determines that banks have a permanent compliance function that assists senior management in managing effectively the compliance risks faced by the bank. The compliance function must be independent of the business activities of the bank. The Supervisor determines that the Board exercises oversight of the management of the compliance function.

Directive 301 sets a general requirement that the board of directors verify that the banking corporation operates in compliance with laws and regulations. Besides, Directive 308 formally requires the appointment of a compliance officer responsible for matters pertaining compliance with consumer regulations within the banking corporation, i.e. those pertaining to banking activity in Israel with regard to the relations between the bank and its customers, including the Prohibition of Money Laundering Law and the Prohibition of Money Laundering Order.

BSD uses off-site and on-site examinations to assess the functioning of the compliance officer.

On-site examinations in this respect are conducted by a dedicated examination team. For the most part, the matters examined relate specifically to consumer compliance (e.g., mortgage lending and switching banks by customers) and the functioning of the compliance officer.

EC-7: The Supervisor determines that banks have an independent, permanent and effective internal audit function charged with (i) ensuring that policies and processes are complied with and (ii) reviewing whether the existing policies, processes and controls remain sufficient and appropriate for the bank's business.

The Banking Ordinance, 1941 requires every bank to appoint an internal auditor. The board of directors is responsible for the appointment, termination or suspension of this internal auditor, pursuant to a recommendation from the audit committee. Directive 301 sets a number of rules, regarding the independence of the internal audit function, in particular the subordination of the internal auditor to the chair of the board of directors and its accountability to the latter, the whole board of directors and the audit committee

The Banking Ordinance, 1941 also assigns the internal auditor with duties, including the review of the proper functioning of the bank, the preservation of its integrity, economy, efficiency, maintenance of proper banking practice, and its compliance with laws and regulations. A large number of directives complement the duties which fall on the internal auditor, regarding the assessment of the capital adequacy (Directive 211), the risk management (Directive 339), the IT environment (Directive 357), and the Anti-Money Laundering processes (Directive 411). (BSD published at the end of December 2011, a new Directive 307 dealing with Internal Audit. The new directive is meant to serve as a comprehensive framework for the work of the internal auditor and the internal audit function.)

BSD staff reviews the audit work plan, important audit reports, the auditor's reports on 
the correction of faults discovered in $\mathrm{h} / \mathrm{her}$ audit reports, and $\mathrm{h} / \mathrm{her}$ relations and functioning vis-à-vis the audit committee. BSD also examines audit functioning, either generally or as part of the examination of a specific risk (credit, market, operational, compliance, etc.). The unit that examines corporate governance performed comprehensive examinations of the entire banking system in two matters: the organizational structure and control environment of the internal audit function, and the internal auditor's work plan and its compatibility with the scope and nature of the bank's activity.

EC-8: The Supervisor determines that the internal audit function:

- has sufficient resources, and staff that are suitably trained and have relevant experience to understand and evaluate the business they are auditing;

- has appropriate independence, including reporting lines to the Board and status within the bank to ensure that senior management reacts to and acts upon its recommendations;

- has full access to and communication with any member of staff as well as full access to records, files or data of the bank and its affiliates, whenever relevant to the performance of its duties;

- employs a methodology that identifies the material risks run by the bank;

- prepares an audit plan based on its own risk assessment and allocates its resources accordingly; and

- has the authority to assess any outsourced functions.

The appointment of a bank's internal auditor requires the approval of the Supervisor of Banks (Banking Ordinance, 1941). The Internal Audit Law empowers the internal auditor to request and receive any document and information in the possession of the bank. The Banking (Internal Audit) Rules, 5753-1992 also requires the internal audit function to base its work plan on a mapping of the risks inherent to the banking corporation's activities. However, BSD directives do not explicitly address the coverage of outsourcing by internal audit, with the only exception of IT outsourcing (Directive 357). (This explicit requirement is included in the new Directive 307 issued in December 2011 (see EC-7).)

AC-1: In those countries with a unicameral Board structure (as opposed to a bicameral structure with a Supervisory Board and a Management Board), the Supervisor requires the Board to include a number of experienced non-executive directors.

Directive 301 prohibits employees of the bank from serving as members of the board of directors.

AC-2: The Supervisor requires the internal audit function to report to an audit committee, or an equivalent structure.

Directive 301 states that the internal audit function is subordinate to the chairman of the board of directors and reports to the board via the audit committee, and sets the process of discussing audit reports. The Banking (Internal Audit) Rules, 5753-1992 that requires the internal auditor to present the audit committee and the CEO with periodic reports in writing (a semi-annual report and an annual report). The Banking Ordinance, 1941, that requires the internal auditor to submit audit reports and reports on findings to the chairman of the board of directors, the director-general, and the chairman of the audit committee.

AC-3: In those countries with a unicameral Board structure, the Supervisor requires 


\begin{tabular}{|c|c|}
\hline & $\begin{array}{l}\text { the audit committee to include experienced non-executive directors. } \\
\text { Directive } 301 \text { states that a majority of members of the audit committee must be } \\
\text { outside directors and that the chair of the committee must be an outside director. } \\
\text { Furthermore, at least two directors on the committee must have accounting and } \\
\text { financial expertise. } \\
\text { AC-4: Laws or regulations provide, or the Supervisor ensures, that banks must notify } \\
\text { the Supervisor as soon as they become aware of any material information which may } \\
\text { negatively affect the fitness and propriety of a Board member or a member of the } \\
\text { senior management. } \\
\text { Directive } 301 \text { states that any officer who is subject to a fit and proper process } \\
\text { (accordingly a board member or a member of the senior management) must serve } \\
\text { notice through the bank about events or changes in certain details that relate to his } \\
\text { integrity, financial robustness, or an appointment as a director or CEO in additional } \\
\text { corporations. Then the Supervisor considers whether to order the termination of the } \\
\text { office holder's term (Banking Ordinance, 1941). }\end{array}$ \\
\hline Assessment & Largely compliant \\
\hline Comments & $\begin{array}{l}\text { The legal and regulatory framework is characterized by a very large number of laws, } \\
\text { directives and supervisory letters, which reflect a piecemeal approach to the } \\
\text { regulation of internal control and audit function. This leads to a very complex structure } \\
\text { of rules, which are not always consistent between themselves (e.g. regarding } \\
\text { reporting by the internal auditor) and does not allow for a comprehensive rulebook. } \\
\text { The BCP assessors have taken note that BSD is working on a new, comprehensive } \\
\text { directive concerning the internal audit function, which will specify the required } \\
\text { characteristics of this function and strengthen the internal auditor's status. } \\
\text { BSD is strongly encouraged to move forward in this direction. It could take the } \\
\text { opportunity of this revision of its regulatory framework to fill the following gaps: } \\
\text { - the principles relating to the organizational structure in terms of segregation } \\
\text { of critical functions, such as business origination, payments and settlements, } \\
\text { reconciliation (EC2); } \\
\text { the compliance function, the scope of which is limited to consumer } \\
\text { regulations (including AML/CFT regulations) and accordingly does not meet } \\
\text { international standards (EC6), } \\
\text { the ability of a bank's internal audit to access any outsourced functions (EC8). } \\
\text { Despite these shortcomings, it should be emphasized that BSD is devoting a large } \\
\text { amount of supervisory work to the assessment of the effectiveness of the internal } \\
\text { control and audit functions and must be commended for its pro-active approach in this } \\
\text { field. }\end{array}$ \\
\hline Prin & $\begin{array}{l}\text { Abuse of financial services. Supervisors must be satisfied that banks have } \\
\text { adequate policies and processes in place, including strict "know-your-customer" rules, } \\
\text { that promote high ethical and professional standards in the financial sector and } \\
\text { prevent the bank from being used, intentionally or unintentionally, for criminal } \\
\text { activities. }\end{array}$ \\
\hline Des & $\begin{array}{l}\text { EC-1: Laws or regulations clarify the duties, responsibilities and powers of the banking } \\
\text { Supervisor and other competent authorities, if any, related to the supervision of banks' } \\
\text { internal controls and enforcement of the relevant laws and regulations regarding } \\
\text { criminal activities. } \\
\text { AML/CFT provisions and practice are generally of a high standard. A new regulation } \\
\text { to complete and harmonize the regulatory framework was in the process of being } \\
\text { issued at the time of the assessment. Israel's statutory framework has adopted the }\end{array}$ \\
\hline
\end{tabular}


AML/CFT standards of the FATF (Financial Action Task Force) and empowers the Governor to require banks to discharge the obligations and responsibilities of an adequate AML/CFT regime as set forth in the Prohibition of Money Laundering Law (the Law) and as set forth in the Prohibition on Financing of Terrorism Law. The Law empowers the Governor to issue an order containing detailed provisions for the discharge of the obligations of banks (including auxiliary corporations). The powers that these supervisors may exercise vis-à-vis these corporations include receiving information, conducting checks, seizing documents, etc. The Governor is also empowered to establish a sanctioning committee for the financial sanctioning of any violation of the Prohibition of Money Laundering Law.

Consequent to this power, the Governor enacted an Anti-Money-Laundering Order. The Supervisor issued Directive 411 in accordance with the authority vested in him in the Banking Ordinance, 1941 to issue directives to the banking corporations. The Supervisor also sets out requirements through letters and circulars. Concurrently, Israel established a Financial Intelligence Unit-the Israel Money Laundering and Terror Financing Prohibition Authority (IMPA) — tasked with managing, processing, and protecting the database that the law requires and with sharing information with those authorized to receive it.

A dedicated team composed of six examiners was set up to conduct on-site examinations and, in most cases, a general comprehensive examination that covers most issues related to the enforcement of legislation and regulations, including KYC policies, the functioning of the AML/CFT Designated Officer (DO), reporting to IMPA, documents list, opening-of-account procedures (especially the identification and verification of particulars), use of a list to monitor terror organizations and activists, training, monitoring and supervision of high-risk customers, etc. These examinations take place at banks and auxiliary corporations, but never at foreign branches or subsidiaries. Foreign branches or subsidiaries are covered using alternative tools including, inter alia, requirements regarding the connection between the Designated Officer and foreign branches and subsidiaries, evaluating and examining the banking group coverage, reviewing the work of the internal auditors and the host regulators audit reports. The authorities feel that on-site examination in that area would not be useful because the examiners would have to have expertise in AML/CFT and other local laws of each country. In addition, BSD requires that whenever the provisions in the foreign country differ from Directive 411 , then the stricter provisions shall apply insofar as they do not contravene the local law.

EC-2: The Supervisor must be satisfied that banks have in place adequate policies and processes that promote high ethical and professional standards and prevent the bank from being used, intentionally or unintentionally, for criminal activities. This includes the prevention and detection of criminal activity, and reporting of such suspected activities to the appropriate authorities.

Directive 411 requires the board of directors to establish an appropriate AML policy, that will include customer due diligence policy and procedures that should prevent the bank from being used, intentionally or unintentionally, for criminal activities. The purpose is to detect, prevent, and identify criminal activities and report them to the competent authorities.

The statutory framework requires banks to present IMPA with a report by type and size (Currency Transaction Report) and a report on irregular activity (Suspicious Transaction Report) whenever banks detect it. In cases of suspected activity relating to financing of terror, the transaction must be blocked at once and reported to the defense authorities and IMPA. 
BSD bases its AML/CFT on-site examinations on a risk-based approach and a manual that captures the entire range of matters to be checked.

EC-3: In addition to reporting to the financial intelligence unit or other designated authorities, banks report to the banking Supervisor suspicious activities and incidents of fraud when they are material to the safety, soundness or reputation of the bank.

Directive 411 sets reporting requirements to $B S D$, about special events that the banking corporation reported to IMPA, which are material to the soundness and reputation of the banking corporation, such as any investigation with implication related to AML/CTF that is being conducted against the bank and whenever a foreign corporation that the bank controls, or in which it has a substantial interest, or a branch outside Israel, does not act in accordance with the Directive (because the Directive contravenes the provisions of local laws). Banks must also transmit to BSD monthly reports on the number of reports that they sent to IMPA, parsed by types.

According to the Banking Ordinance, 1941, banks must report to the Supervisor any cases of material embezzlement by their staff and officers. In regard to IT, banks must apprise BSD of aberrant events including attempted intrusions and attacks, actual intrusions to computer systems, system collapses, etc (Directive 357).

EC-4: The Supervisor is satisfied that banks establish "know-your-customer" (KYC) policies and processes which are well documented and communicated to all relevant staff. Such policies and processes must also be integrated into the bank's overall risk management. The KYC management program, on a group-wide basis, has as its essential elements:

- a customer acceptance policy that identifies business relationships that the bank will not accept;

- a customer identification, verification and due diligence program; this encompasses verification of beneficial ownership and includes risk-based reviews to ensure that records are updated and relevant;

- policies and processes to monitor and recognize unusual or potentially suspicious transactions, particularly of high-risk accounts;

- escalation to the senior management level of decisions on entering into business relationships with high-risk accounts, such as those for politically exposed persons, or maintaining such relationships when an existing relationship becomes high-risk; and

- clear rules on what records must be kept on consumer identification and individual transactions and their retention period. Such records should have at least a five year retention period.

The board of directors is required (through Directive 411) to establish a KYC policy that includes a "KYC upon opening an account" procedure, classification of high-risk customers, different KYC rules for different kinds of customers, monitoring of account activity, and monitoring of high-risk customers. Management must establish KYC procedures in accordance with the board of directors' policy to assure ethical and professional standards that will prevent the bank from being used, intentionally or unintentionally, for criminal activities.

Pursuant to an examination performed by MoneyVal in 2007-2008, the Governor decided to anchor KYC obligations in legislation by amending the Anti-MoneyLaundering Order. The amendment, still pending, will anchor some provisions set out in Directive 411 (mainly relating to customer due diligence, correspondent banking) also in legislation. 
The AML Order requires the retention of customer identification documents for at least seven years after the account is closed or after the performance of transactions.

Banks must maintain a computerized database of account numbers and identifying particulars of account holders, authorized signatories, beneficiaries, and controlling principals. They must also retain documentation, or record, of any instruction in a sum of NIS 10,000 or more for a period of at least seven years from the date on which it is recorded.

Where high-risk customers are concerned, a banking corporation must establish, in its procedures, special rules for the definition of such customers and must take enhanced KYC measures (Directive 411).

The KYC topic is paid high attention to in AML/CFT on-site examinations.

EC-5: The Supervisor is satisfied that banks have enhanced due diligence policies and processes regarding correspondent banking. Such policies and processes encompass:

- gathering sufficient information about their respondent banks to understand fully the nature of their business and customer base, and how they are supervised; and

- $\quad$ not establishing or continuing correspondent relationships with foreign banks that do not have adequate controls against criminal activities or that are not effectively supervised by the relevant authorities, or with those banks that are considered to be shell banks.

Directive 411 requires banks to adopt a risk-based approach and to understand the essence of the businesses of their respondent banks. Banks must perform enhanced due diligence (including the collection of information about respondent banks' business activity, the place where they do business, their efforts in regard to AML/CFT, their purpose in opening an account, the condition of supervision and regulation related to AML/CFT in the country where the bank and the correspondent, and the obtaining of various documents). In addition, a new correspondent relationship must be approved by a senior manager of the bank.

The directive also forbids the maintenance of correspondent relations with financial institutions that are not supervised in regard to AML/CFT, with a shell bank, and with a financial institution that allows its accounts to be used by a shell bank.

Banking corporations' policies and procedures concerning the management of correspondent accounts are examined in the course of on-site examinations.

EC-6: The Supervisor periodically confirms that banks have sufficient controls and systems in place for preventing, identifying and reporting potential abuses of financial services, including money laundering.

Banks' ability to identify, prevent, and report AML/CFT events is tested in AML/CFT examinations. Such examinations include review of support systems for the detection of irregular activities, including the system's design documents; effectiveness in detecting irregular activities; and how the corporation uses the system. The examinations examine samples of customer transactions via files and samples that contain details on accounts and customers in accordance with the bank's focal points of risk.

One of the objectives is to detect irregular activity that a bank was supposed to report to IMPA pursuant to alerts from the irregular activity detection system, exceptional event reports, or reporting by members of the bank's staff. The examinations also 
examine the contents of the training provided by the bank in terms of its frequency, content, scope, and correspondence of its contents to different types of staff (managers, newly hired employees, etc.); the resources available to the AML/CFT Designated Officer, the controls that $\mathrm{s} /$ he applies over the assimilation of staff knowledge, etc.

EC-7: The Supervisor has adequate enforcement powers (regulatory and/or criminal prosecution) to take action against a bank that does not comply with its obligations related to criminal activities.

The Supervisor is empowered to issue directives to banks by force of the Banking Ordinance, 1941. He may demand the correction of deficiencies and take measures against a bank that fails to comply with these directives (see details in CP-1(4) and CP-23). The publication in May 2011 of new rules enacted by the Governor pursuant to Section 14I(b) of the Banking Ordinance, 1941 has allowed the Supervisor to reduce the amount of financial sanctions he can impose according to Section $14 \mathrm{H}$ of the above-mentioned Ordinance. Thereby the Supervisor is now able to use more gradual sanctions, commensurate with the severity of the violations of Directive 411 .

In addition, the Prohibition of Money Laundering Law empowers the Governor to establish a financial sanctioning committee. The committee is chaired by the Supervisor and is authorized to determine that a bank has violated its AML/CFT obligations (as set forth in the Prohibition of Money Laundering Law and consequently the obligations set forth in the AML Order) and to impose financial sanctions on it. Thus:

- With regard to AML/CFT issues: the sanctioning committee is currently empowered (by section 14 of the Law) to impose a financial sanction on a banking corporation with regard to breaches of varied obligation under the AML Order. The AML Order sets forth comprehensive and detailed obligations. The sanctioning committee is empowered to impose financial sanctions on a bank for a breach of each obligation, separately and it did so in the cases mentioned below. The AML Order is being amended because Moneyval examiners recommended that some of the specifications that are currently included in Directive 411 should be included in the AML Order. A by-product of the amendment may be broadening the range of potential breaches, but this was not the reason for Moneyval to require it. Thus the Supervisor currently has adequate and vast enforcement powers in that area, even prior to the approval of the amendment of the AML Order.

- With regard to other banking activities: although in the past the Supervisor did not use financial sanctions as an enforcement tool, he can now use it if necessary and has recently started to do so.

Between 2008 and 2011, financial sanctions due to breaches of obligations under the Prohibition of Money Laundering Law were imposed on five banking corporations in an aggregate amount of NIS 16.9 million.

In addition, the Supervisor has enforcement powers that derive from his general authority, e.g. addressing demands to the board of directors and management of the bank to correct deficiencies (detected in the course of examinations or from reports to various entities such as IMPA or that come to BSD's knowledge).

EC-8: The Supervisor must be satisfied that banks have:

- requirements for internal audit and/or external experts to independently evaluate the relevant risk management policies, processes and controls. The Supervisor must have access to their reports;

- established policies and processes to designate compliance officers at the 
management level, and appointed a relevant dedicated officer to whom potential abuses of the bank's financial services (including suspicious transactions) shall be reported;

- adequate screening policies and processes to ensure high ethical and professional standards when hiring staff; and

- ongoing training programs for their staff on $\mathrm{KYC}$ and methods to detect criminal and suspicious activities.

The Prohibition of Money Laundering Law requires banks to appoint an officer in charge of satisfying its obligations under this Law. According to Directive 411, this dedicated officer (DO) must be a member of the bank's management or someone directly subordinate to a member of management who is not responsible for an area in which business operations take place.

Directive 411 requires banks to subject the adequacy and effectiveness of the DO's working structure to periodic auditing by internal audit and to assign appropriate resources for the examination of compliance in this matter. BSD has access to the internal auditor's reports on every subject, including AML/CFT. Banks are required to have procedures assuring the maintenance of high standards for the hiring of new employees, commensurate with the nature of the position in the context of AML/CFT (Directive 411). Training programs should be performed on an-going basis on customer identification and due diligence, with due attention paid to AML/CFT regulations.

AML/CFT on-site examinations include reviews of the relations between the $\mathrm{DO}$ and the internal audit function, the AML/CFT policies, procedures, the functioning of the DO and his staff, the staff training programs.

EC-9: The Supervisor determines that banks have clear policies and processes for staff to report any problems related to the abuse of the banks' financial services to either local management or the relevant dedicated officer or to both. The Supervisor also confirms that banks have adequate management information systems to provide managers and the dedicated officers with timely information on such activities.

Directive 411 requires that the bank's management establishes customer duediligence procedures. The DO is held responsible for providing management with frequent and accessible information about AML/CFT activity. To this end, he must have unlimited access to all records and information about customer identification and additional KYC documents, transaction documents, and all other relevant information.

In the AML/CFT examinations, the completeness and currency of banks' policies, proceedings, and procedures in regard to reporting of irregular activity, including internal controls and ongoing oversight for the detection and identification of such activities in all areas of bank business are examined. The effectiveness of the bank's detection and reporting systems in light of the volume of activity, and the adequacy of the AML/CFT unit's activity in identifying, detecting, and reporting irregular activity are also examined. However, BSD examiners do not avail of specific data-processing tools, and work with Excel spreadsheets only.

EC-10: Laws and regulations ensure that a member of a bank's staff who reports suspicious activity in good faith either internally or directly to the relevant authority cannot be held liable.

The Prohibition of Money Laundering Law states that good-faith reporting in accordance with the provisions of this Law does not constitute a breach of confidentiality and trust and that such a whistle-blower shall not incur criminal, civil, or 
disciplinary liability for having taken such action.

EC-11: The Supervisor is able to inform the financial intelligence unit and, if applicable, other designated authority of any suspicious transactions. In addition, it is able, directly or indirectly, to share with relevant judicial authorities information related to suspected or actual criminal activities.

The IMPA is not included in the scope of the authorities to whom, according to Section 15A of the Banking Ordinance, 1941, the Governor is empowered to forward information, among which, any suspicious transaction entered into by a bank. However, based on Section 9 of the Prohibition and Money Laundering Order and by virtue of his powers vested in him by Section 5 of the Banking Ordinance, 1941, the Supervisor is able to instruct a bank to report such a suspicious transaction to the IMPA.

On the other hand, according to Section 15A of the Banking Ordinance, 1941, information related to criminal activities can be forwarded to judicial authorities by the Governor provided he deems it necessary for the purposes of a criminal charge or if such information was received from a bank that consents to its disclosure.

EC-12: The Supervisor is able, directly or indirectly, to cooperate with the relevant domestic and foreign financial sector supervisory authorities or share with them information related to suspected or actual criminal activities where this information is for supervisory purposes.

The Banking Ordinance, 1941 enables the Supervisor to forward information in his possession to a foreign supervisory authority that is responsible for supervising a branch or a subsidiary of a banking corporation that is incorporated in Israel or a branch of a foreign bank that operates in Israel, or a foreign bank that is controlled by a banking corporation. However, such information may be shared only if the competent authority needs it for the discharge of its duties in supervising the stability of the relevant entity and if this authority confirms that it is subject to confidentiality requirement similar to Israeli ones or it has undertaken not to share information with any other party. In addition, such information may only be shared if it has not been found liable to impair a pending investigation or state security.

Likewise, the Supervisor may share information with Israeli authorities-the ISA and the Commissioner of the Capital Market, Insurance, and Savings at the Ministry of Finance-provided that the information is needed for the discharge of their duties.

In practice, cooperation with domestic and foreign authorities in regard to irregular activity is handled mainly by IMPA on the basis of existing legislation. Relations with foreign supervisors may also include AML/CFT issues (see also CP25).

AC-1: If not done by another authority, the Supervisor has in-house resources with specialist expertise for addressing criminal activities.

The examiners at the dedicated examination unit receive ongoing training in AML/CFT issues that arise as a result of the examinations of banking corporations. They participate in training, workshops, and in-service activities and read material that is published in Israel and abroad on the topic.

\begin{tabular}{|c|l|}
\hline Assessment & Largely compliant \\
\hline Comments & $\begin{array}{l}\text { The supervisory practice seems well-suited and has resulted in nine financial } \\
\text { sanctions, on five banking corporations, over the last three years. So far, however, } \\
\text { financial sanctions could only be based on breaches of obligations under the } \\
\text { Prohibition of Money Laundering Law and the AML Order. Only after the amendment } \\
\text { to the Order (currently under approval of the Constitution, Law and Justice Committee }\end{array}$ \\
\hline
\end{tabular}


of the Knesset) is passed, will the range of provisions likely give rise to financial sanctions in case of breaches extended. It is important that the new AML/CFT regulation for banks should be adopted and implemented.

The AML policy, including risk management, customer acceptance and identification policies, and monitoring of accounts, are to be applied on a group basis. However, for lack of formal mechanisms with other foreign supervisory authorities (apart from the US authorities), the intensity and depth of the information-sharing with such authorities has not been extensively tested. In view of the limited occasion for on-site examinations to the banks and their branches or subsidiaries incorporated outside Israel, more cooperation with foreign authorities would enhance the effectiveness of policies and processes that banks have put in place on a consolidated basis to meet high ethical and professional standards and prevent them from being used for criminal activities.

Principle 19. $\quad$ Supervisory approach. An effective banking supervisory system requires that supervisors develop and maintain a thorough understanding of the operations of individual banks and banking groups, and also of the banking system as a whole, focusing on safety and soundness, and the stability of the banking system.

Description

$\mathrm{BOI}$ practices risk-based supervision. The framework of risk-based supervision was developed and implemented in 2008 with direct technical assistance from the Office of Supervision of Financial Institutions (Canada) and the Hong Kong Monetary Authority. The bank supervisors have developed a supervisory cycle which underpins the riskbased process. It is a five-stage cycle culminating in two critical processes: developing a view of risk on a consolidated basis for each banking corporation in Israel; and developing a supervisory strategy for each of the institutions. The program enables the bank supervisors to take a more forward-looking view of the risks in each banking corporation based on the type of information evaluated and the risk-based processes employed.

Both the off-site and on-site supervision units play critical roles in the program. The off-site unit is responsible for taking a view of the risk in each banking corporation holistically. Analysts are organized by and assigned to the oversight of a specific banking organization. They are involved actively in gaining an understanding of the risk profile and corporate culture of the assigned institution, and in assessing the risk in the institution both on a consolidated basis, by product line and by type of risk. The evaluation of risk is translated into supervisory products - a risk matrix and a risk map - that reflect the qualitative assessments of risk based on significant banking activities and type of risk.

With the perception of risk established, development of the supervisory strategy is developed. The strategy, called a supervisory plan or work plan, is a joint effort by the off-site and on-site units. The risks are prioritized and decisions made relative to the supervisory activities for the banking corporation. The plan is a mix of on-site examinations and targeted visits, meetings regarding specific supervisory issues or concerns, and other activities as warranted.

At the end of the cycle, an evaluation of the banking corporation is developed indicating the strengths and weakness in the corporation, level and nature of risk in major business lines and risk areas. A management tool utilized in this stage, and in the overall evaluation of risk as manifested in the risk matrix and risk map, is the assignment of quantifiable risk ratings to both business risk and type of risk. As an example, ratings such as Strong, Acceptable, Needs Improvement and Weak are assigned for risk management capacity. The evaluation of risk as contained in the risk matrix, risk map and the overall evaluation are subject to change at any time, based on a perceived change in the risk profile of the banking corporation. It is, therefore, a continuous supervisory process rather than a point-in-time process. 
During the course of the supervisory cycle, analyses of risks in business lines and products, and in specific risks such as liquidity risk are prepared. Such analyses also are prepared on areas of corporate governance and risk management to reflect the capacity of those responsible for oversight, including senior management and the internal auditor in the management of the bank.

On-site work is based on the perceived level of risk emanating from the risk evaluations that are conducted off-site, and the scope of examinations typically reflect the areas and business lines selected for examination because of risk issues. Fullscope examinations are no longer conducted. Unlike the off-site unit, the organizational structure of on-site reflects a division by type or risk. There are five such risk units, with examiners in each specializing in one or more of the risks.

The risk-based framework for banking supervision is complemented by the Supervisory Review and Evaluation Process (SREP) in which a banking corporation's capital adequacy is tested against its risk profile within the framework of Pillar 2 in the Basel II Accord. The emphasis during the SREP process is to identify principal exposures and deficiencies in corporate governance, internal control and risk management processes. To reach conclusions on these issues, the banking corporation's risk profile is quantified in a series of 19 risk cards that grade: the six principal banking risks (credit, market, liquidity, operational, reputational and strategic); capital management and capital stability; and corporate governance Source documents include both on-site and off-site reports and other supervisory evaluation techniques both qualitative and quantitative.. This process enables the supervision staff to compare the performance of each of the banking corporations and identify areas of weakness relative to each of them in any of the areas quantified. The process also assists analysts in determining whether a banking corporation may require additional capital based on its overall score relative to its existing capital base. The results also are fed into the risk matrix and risk map to provide a comprehensive view of risk for each institution.

To further gauge risk, the banking corporations are required to conduct what is in effect a self-assessment of its risk management practices on an annual basis. This self-assessment, or ICAAP, is filed with the Supervisor of Banks, and it is used as another tool to evaluate risk management processes in each banking corporation. The results of these assessments have implications as well for the perception of risk and capital adequacy, and are employed in the risk evaluation documents and the supervisory strategy.

The risk-based approach facilitates the assessment of trends in the banking system. The SREP process has as a prime feature an ability to compare institutions and to assess trends in the industry based on a deeper and wider base of information than was available prior to its introduction. As a result, analyses of developments in the banking industry, on capital adequacy and an array of other issues is prepared on an ad hoc basis, but not necessarily by the off-site unit.

The bank supervisors review compliance with banking laws and regulations employing both risk-based and rules-based supervision. While on site, examiners review compliance with prudential requirements, and off-site staff, combined with the logical mechanisms embedded in the automated platform for the filing of supervisory reports, are able to identify compliance with certain prudential standards and laws. But the principal focus is to ensure that the banking corporation has appropriate risk management practices established, either through a compliance officer, risk management unit or other similar means, to manage and control compliance risk.

Banks are required to notify the Supervisor of Banks in the event of a material change in its activities or structure. The licensing and permit process results in the granting of 


\begin{tabular}{|c|c|}
\hline & $\begin{array}{l}\text { a permit that restricts a bank or its affiliated subsidiaries to activities contained in the } \\
\text { permit if a subsidiary, or contained in the law if a bank. To change its activities, or } \\
\text { modify its ownership structure the subsidiary must seek approval to do so. Moreover, } \\
\text { Directive } 301 \text { requires management to notify the Supervisor of Banks of certain events } \\
\text { that affect the financial condition of a banking corporation or materially damage the } \\
\text { interests of the bank's creditors, customers or shareholders. } \\
\text { The Supervisor has dedicated information systems to facilitate the processing and } \\
\text { monitoring of supervisory data. BOI is nevertheless in the process of upgrading the } \\
\text { information infrastructure to improve the platform under which supervisory reports are } \\
\text { filed because the existing system is old and its overall reliability has come under } \\
\text { question. The upgrades are expected to take several years to complete, however. } \\
\text { Another area under the responsibility of the Supervisor of Banks is consumer } \\
\text { protection activities, consisting principally of the treatment of consumer complaints } \\
\text { and the level of fees charged by banks for various services. For consumer complaints, } \\
\text { the analysts in the unit are involved in the resolution of legitimate complaints about } \\
\text { service and other issues. In the matter of fees, the analysts are involved in the } \\
\text { development of legislation and regulations, identification and correction of systemic } \\
\text { problems relating to fee structures, on-site consumer protection examinations, and the } \\
\text { advancement of consumer awareness. There is some useful information derived from } \\
\text { these responsibilities, particularly from the examination program, that is employed in } \\
\text { the risk-based supervision. Findings from complaints have on occasion served as a } \\
\text { basis for remedying deficiencies in a bank or in the whole banking sector (for } \\
\text { example, in the evaluation of banks' operational risks, including the SREP process, } \\
\text { but also through amendments to consumer protection regulations). }\end{array}$ \\
\hline Asse & Compliant \\
\hline Comments & $\begin{array}{l}\text { BOl's risk-based supervision program, only in existence for three years, has } \\
\text { revolutionized the manner in which the supervisors evaluate banking corporations. } \\
\text { Nevertheless, the program remains in its evolutionary stage and the supervisors still } \\
\text { are transitioning from a compliance-based approach. The supervisors, while gaining } \\
\text { experience in determining critical information and assessing it effectively, must seek } \\
\text { ways to become more efficient in the application of the program. There is recognition } \\
\text { that some aspects of the program are duplicative and that a balance needs to be } \\
\text { achieved in the use of detailed information. On-site examination reports are moving } \\
\text { towards a risk-based approach, but there are elements of them that need to be further } \\
\text { refined that could make them even more risk-focused. These issues were discussed } \\
\text { at length with the supervisors. } \\
\text { More use from a supervisory perspective can be derived from the consumer protection } \\
\text { activities. In particular, data should be sorted from the number and type of legitimate } \\
\text { complaints that would enable the analysts to determine whether there were any } \\
\text { common patterns relative to a consumer practice common to all the banks, from which } \\
\text { a directive or supervisory letter could be issued. Collecting data on complaints by the } \\
\text { number for each bank is relevant in dealing with issues in a particular banking } \\
\text { corporation, but analyzing the data across the system may be more revealing. The } \\
\text { results could also be better used in the evaluation of operational risk. }\end{array}$ \\
\hline Principle 20. & $\begin{array}{l}\text { Supervisory techniques. An effective banking supervisory system should consist of } \\
\text { on-site and off-site supervision and regular contacts with bank management. }\end{array}$ \\
\hline Description & $\begin{array}{l}\text { BOI employs a combination of on-site and off-site supervision to evaluate the } \\
\text { condition of banks, the management of the risks they incur in their operations, and to } \\
\text { determine the supervisory measures that may be needed to address identified } \\
\text { concerns. The appropriate mix of supervisory activities is defined in a supervisory } \\
\text { strategy, or work plan that enumerates the supervisory activities that will be carried } \\
\text { out for each banking corporation. While the plan is developed for a year's duration, it } \\
\text { is continuously revised as circumstances dictate and as perception of risks shift. The }\end{array}$ \\
\hline
\end{tabular}


plan is a collaborative effort between the off-site and on-site units.

Off-site supervision consists of five units, comprised of 27 analysts. Each unit is responsible for one of the five large banking corporations, with several of them having responsibility for one of the smaller banking institutions as well. The units are responsible for formulating the overall risk assessment of each institution, with specific reference to the level and types of risk in the institutions. Sources of information include the Risk Map, SREP and ICAAP, information obtained through routine contacts, data from supervisory returns and public financial reports, and other sources available to them. The overall assessments, in which a view of risk for the entire institution is present, are "living" documents in the sense that the risk profiles of the banking corporations are subject to virtually continuous review based on the analyses of business lines and risk areas in the bank.

On-site supervision is organized along risk lines rather than institutional lines. There are five specialized units whose responsibility is to examine one of the principal banking risks. There are 33 examiners in on-site supervision, with approximately five examiners assigned to each unit. Each unit examines the risk in which there is a specialization across the banking industry, facilitating comparison between institutions and identification of risk issues from an industry perspective.

On-site and off-site processes are integrated into the supervisory plan. During the supervisory cycle (BCP 19), on-site examiners conduct planned examinations addressing risks identified as higher priority, combined with targeted examinations as necessary. Off-site supervision prepares quarterly analyses about the financial condition of each banking corporation, management of risk in lines of activity, and corporate governance functions. To ensure the supervisory plan is valid, the analyses provide recommendations for continued supervisory treatment, expansion of monitoring or on-site activities, or other modifications to the supervisory plan as warranted.

On-site examinations, inter alia, test the credibility of information reported by banks as part of testing of financial records and management information systems. The tests are conducted to verify the quality of risk management and internal controls as well. Depending on examination results, a course of remedial action may be required. The monitoring of deficiencies that warranted the supervisory action occurs in off-site supervision, and may consist solely of a response letter from the bank describing the manner in which corrective measures may be taken, or a series of progress reports if the issues are more complex and serious, and which may take longer to resolve. Targeted follow-up visits by the on-site examiners may occur as well to verify progress, or there may be follow up meetings with senior management.

The bank supervisors at all levels have a nearly constant stream of contact with the banks. The Governor and the Supervisor of Banks hold quarterly meetings with the CEO and Chairperson of the Board for each banking corporation. The Supervisor of Banks has a further annual meeting with the board of directors and has meetings with the CEO and members of the senior management team as required, and to discuss external audit and supervisory examination results. Unit heads and analysts meet as needed with the CEO and senior management to discuss strategic issues, the bank's performance product lines and risk areas, and risk management broadly in connection with the risk assessment process. Examiners hold meetings with senior management and unit managers in connection with the examination process. Another important set of meetings is held in connection with the annual ICAAP results, in which the methodology employed by the bank to calculate capital assigned to each major banking risk, stress testing results and risk management practices are reviewed.

The stream of contact with the board and senior management of each institution 


\begin{tabular}{|c|c|}
\hline & $\begin{array}{l}\text { facilitates an assessment of the capacity of the board and executive management on } \\
\text { an on-going basis. One of the units in on-site supervision focuses on corporate } \\
\text { governance functions, and is well-placed to evaluate their capacity in a more intense } \\
\text { review. These reviews focus on management processes rather than the competence } \\
\text { of senior executives. They have the added advantage of providing perspective on } \\
\text { management capacity across the banking industry. } \\
\text { The internal audit function is one of the areas placed under scrutiny by the corporate } \\
\text { governance examiners and by off-site analysts. Based on the results of these } \\
\text { examinations, the work of the internal audit function may be relied upon, or the } \\
\text { examination work may complement the work of the auditors. The SREP process also } \\
\text { includes a set of risk cards for the internal audit function so that off-site supervision } \\
\text { evaluates the capacity of the function in relation to the overall quality of the risk } \\
\text { management framework in each bank. }\end{array}$ \\
\hline Assessment & Compliant \\
\hline Comments & $\begin{array}{l}\text { Notwithstanding the learning curve the supervision staff is working through in } \\
\text { implementing risk-based supervisory processes, the staff is to be commended in the } \\
\text { progress made to date. While the process can be made more efficient, there is a clear } \\
\text { need to expand the staff so that full implementation can be effected. The few small } \\
\text { banks have been subjected to the risk-based process, but, but on a narrower scope } \\
\text { than the large banks. Work on other critical areas associated with risk management, } \\
\text { such as in-depth examinations of the adequacy of implementation of Basel II and } \\
\text { issues related to market risk have suffered delays as a result of resource shortages } \\
\text { (these issues are addressed elsewhere in the assessment). }\end{array}$ \\
\hline Princi & $\begin{array}{l}\text { Supervisory reporting. Supervisors must have a means of collecting, reviewing and } \\
\text { analyzing prudential reports and statistical returns from banks on both a solo and a } \\
\text { consolidated basis, and a means of independent verification of these reports, through } \\
\text { either on-site examinations or use of external experts. }\end{array}$ \\
\hline Description & $\begin{array}{l}\text { Section } 5 \text { (a) of the Banking Ordinance, } 1941 \text {, provides the Supervisor of Banks with } \\
\text { the authority to require banks, their subsidiaries and controlled companies, to furnish } \\
\text { on a regular basis information and documentation related to the business of the } \\
\text { banking corporation. This section of the Ordinance is complemented by a set of } \\
\text { directives that serves as instructions and rules governing the preparation of the } \\
\text { reports and the accounting standards to be used, commonly referred to as the } \\
\text { Reporting of BSD Directives. } \\
\text { There are in aggregate } 42 \text { supervisory reports, of which } 19 \text { are reports required on a } \\
\text { solo basis, and the balance on a consolidated basis. The reports provide information } \\
\text { on the full spectrum of supervisory information from financial statement data to related } \\
\text { party and large exposure information, credit and other risks incurred by banks, and } \\
\text { shareholder information, both on activities in Israel and abroad. Depending on the } \\
\text { type of report, it is required to be filed either annually, quarterly or monthly. All banks } \\
\text { file the same set of reports. } \\
\text { The filing of all returns is automated, and the data submitted is manipulated for } \\
\text { statistical purposes on an automated platform to facilitate analysis of the data for } \\
\text { individual banks or holistically. The data is used, inter alia, in trend analysis, peer } \\
\text { group analysis, and for special studies. The automated platform possesses a series of } \\
\text { logical and other checking mechanisms to verify the accuracy of the data, both prior to } \\
\text { and after the data is manipulated. There are no issues of timeliness in filing the } \\
\text { reports by any of the banking corporations. } \\
\text { Compliance with filing supervisory returns has not been an issue, but there is a } \\
\text { supervisory process in the event a bank has a history of filing inaccurate reports or } \\
\text { fails to file them in a timely manner. Ultimately a bank cannot be fined. A typical } \\
\text { strategy is to require a special audit by the bank's external auditor, resulting in a }\end{array}$ \\
\hline
\end{tabular}


detailed action plan outlining corrective measures to resolve the issue.

The reports are prepared based on a mix of U.S. GAAP and IFRS, as are all publicly available financial information in Israel, and the banks' own books. Approximately 15 years ago, in an effort to strengthen accounting and reporting standards for banks, the Supervisor of Banks gradually implemented U.S. GAAP for core assets, which are principally earning assets. Israeli banks have continued to practice U.S. GAAP, and have changed or modified standards to reflect such changes in the United States. With the introduction of IFRS accounting standards to Israel in 2008 for listed nonbank companies, the Supervisor of Banks has begun to gradually shift accounting standards to IFRS as well. To date, only certain non-earning assets such as fixed and intangible assets (referred to at $\mathrm{BO}$ as non-core assets) are accounted for under IFRS. The authorities are awaiting the expected convergence of U.S. GAAP and IFRS on financial instruments prior to implementing IFRS fully, because the banking system currently reports core assets under U.S. GAAP, and because U.S. GAAP is considered by them to be more appropriate. In June 2009 , the Supervisor issued a road map for the adoption process of IFRS standards in the banking sector, stating 2013 as the preliminary target year for starting the implementation regarding core issues. This target date is now under reconsideration due to the delays in the convergence process.

Banking corporations are required to account for assets employing fair value accounting when US GAAP requires it. As part of the infrastructure for establishing a new product line or activity where fair value accounting may apply, in addition to a sound internal control environment, skilled management and adequate policies and procedures, the bank must be able to account for such instruments on a fair value basis, by demonstrating that it has the capacity to reliably measure the instrument and report it accurately. Guidelines on the application of fair value accounting have been issued to the banking industry based on observed deficiencies in the industry's practices, in consultation with auditing firms.

Under the power granted in Section 5 (a) of the Ordinance, the Supervisor of Banks has access to all banking data and documents that are deemed material to determine the safety and soundness of a banking corporation. Any type of bank information is covered, including minutes of meetings of boards of directors and committees thereof and customer accounts.

With the exception of external auditors, the Supervisor of Banks rarely employs external experts as a matter of policy, but when they are, their role and output are clearly defined and monitored. The auditors are retained by banks following a requirement by the Supervisor, to conduct special investigations or studies, or to perform audits of targeted activities. Directive 303 requires that the auditors inform the supervisors of the results of such undertakings, irrespective of whether there are material shortcomings. BSD may also retain external consultants, for example, it retained former regulators from other leading bank supervisory authorities to assist in the development of a risk-based supervisory framework.

Assessment

Compliant

Comments

While it is recognized that the authorities are monitoring developments relative to the convergence of US GAAP and IFRS, it is suggested that they have a supervisory strategy in place which should include informing the banking industry of a date certain in which IFRS will be implemented, the filing of progress reports or other forms of ongoing communication to ensure that individual banks are progressing satisfactorily towards implementation, and a requirement that banks operate a "dual accounting system" for an identified period of time subsequent to implementation of IFRS in the event operating problems occur so as to prevent the compromising of data and other information. 
\begin{tabular}{|l|l|l|}
\hline Principle 22. & Accounting and disclosure. Supervisors must be satisfied that each bank maintains
\end{tabular} adequate records drawn up in accordance with accounting policies and practices that are widely accepted internationally, and publishes, on a regular basis, information that fairly reflects its financial condition and profitability.

Description $\quad$ The Supervisor of Banks is responsible for establishing rules that require banks to maintain financial record-keeping systems and reliable data. The regulations, virtually all of which follow US GAAP, clearly establish the responsibility of management and the board of directors to provide qualitative and quantitative information that fairly reflects the bank's financial condition, and that controls and systems have been established to ensure the reliability and completeness of information. A large crosssection of laws and directives govern this requirement. Section 10 of the Banking Ordinance, 1941, provides the Supervisor of Bank's with the authority to require banks to publish audited financial statements, and The Companies Law assigns the responsibility to the board for approving the bank's annual and quarterly financial statements. Several directives further augment management's role, including the requirement to have a Chief Accounting Officer to maintain records, and the production of a report annually by the bank's external auditors identifying and providing recommendations to resolve deficiencies in the controls for financial reporting. The external auditors also are required to issue a public opinion on the effectiveness of the bank's internal controls for financial reporting. The latter directive was issued in reaction to requirements issued by the SEC in the United States in connection with enactment of the Sarbanes Oxley Act.

By law banks are required to have their financial statements audited by an external auditing firm. As a corporation, in accordance with The Companies Law, banks must retain an external auditor, who is expected to express an opinion on the bank's financial statements subsequent to an audit. By directive, auditors are required to express the financial condition of the bank in accordance with "Israeli GAAP" and the Supervisor's directives and guidance (in practice a combination of US GAAP for earning assets and IFRS for non-earning assets).

Banks are required to prepare all relevant supervisory reports and financial statements disclosed to the public in accordance with fair value accounting standards and have been provided risk management guidance through the issuance of directives for the application of the fair value option. Reporting to Public Directives requires banks to allocate sufficient provisions and that they are made in accordance with US GAAP. The directives instruct banks to report profits net of the appropriate reserve.

Under Section 5.1(c) of the Banking Ordinance, 1941, BOI has the power to set the scope and standards of an external audit. On an ad hoc basis, the Supervisor of Banks may require the auditing firm to perform an audit or include a review of a specific issue or include an activity or area of risk in the audit scope. The Supervisor does not have the authority by law to reject the appointment of an auditor. However, $\mathrm{BOI}$ has established a set of standards to promote independence, expertise and professionalism in the auditing profession. Directive 302 sets a standard for independence and describes requirements relative to the quality of the auditor's work. Directive 301 requires immediate reporting to the Supervisor of Banks for the appointment or termination of an external auditor, regardless of the reason.

Audits are required to be performed in accordance standards set by the Institute of CPAs in Israel, and in accordance with directives issued by the Supervisor of Banks, which requires implementation of US auditing standards. The audit of a banking corporation's annual financial statements requires the application of United States auditing standards. Every new audit standard published in the United States is ultimately adopted by $\mathrm{BOI}$. While it has been the practice for $\mathrm{BOI}$ to require banking corporations to apply the financial reporting system employed by banks in the United States, a preliminary target date for the full conversion to IFRS has been set for 
January 1,2013 , provided there has been a convergence of US GAAP and IFRS. Full conversion to IFRS will not occur prior to the convergence of these accounting standards.

BOl's Reporting to Public directives require detailed disclosure to the public in annual and quarterly financial statements, and in the management review, the board of directors' report, and statements or opinions from directors, management or the external auditor. These directives also include compulsory completion of all disclosure required under relevant accounting standards and disclosure of any other material detail. Guidance and instructions contained in the directives are modeled after disclosure requirements in Pillar 3 of Basel II, SEC standards in the United States, and requirements of US bank supervisors. Banks are required to have a formal disclosure policy in accordance with the Reporting to Public Directive. The policy must indicate that disclosure controls and procedures have been established, and that they are assessed quarterly; disclosure statements must affirm that disclosure policies and practices are effective.

Publicly disclosed financial information includes qualitative and quantitative requirements relating to financial performance and position, risk management strategy and practices, risk exposures, transactions with related parties, and a description of the bank's business, senior management and board of directors.

There are supervisory requirements intended to enforce the disclosure standards. Under Directive 304 and BOl's auditing standards, the banking corporation's external auditor must audit the disclosures in its financial statements, issue an opinion about the quality of the disclosures, inform the bank of a material disclosure issue, and indicate whether the disclosure issue could mislead readers of the statements. The banking supervisors utilize digital tools to determine that disclosed information complies with quantitative disclosure requirements, and there is no mismatch between disclosure in the financial statements and disclosure electronically to the supervisors. On a sample basis, the supervisors review the disclosure relative to specific topic or activity. New disclosure requirements would dictate a full scope review of the quality of disclosure in the banks relative to the new requirement.

The Supervisor of Banks publishes an annual survey of Israel's banking system on its website. The survey captures information and analysis of the activities of the banking system, and provides financial data for the system holistically, including the results of stress testing exercises. A press conference is held the day that the survey results are published to inform the public of its existence.

Banking supervisors and the auditing industry maintain a continuing dialogue, but most of the contacts are with the auditing firms that are responsible for auditing the banks in Israel. Contact with the auditing industry broadly takes the form of periodic meetings in which auditing standards and issues of a systemic nature are discussed. Contact with individual auditing firms typically is in connection with their audit work at the banks, but meetings at the conclusion of audits are not routinely held because BOI receives both the audit report and the accompanying management letter as a matter of policy.

The management letter is a detailed report, commonly referred to as a long-form report, which must include information on all events that are required to be reported under United States auditing standards. These include material deficiencies in internal control, financial reporting, and material events or uncertainties that may raise doubts about the continued existence of the banking corporation as a going concern, or other materially adverse events.

Under Directive 302, the engagement partner who is in charge of an audit, and the 


\begin{tabular}{|c|c|}
\hline & $\begin{array}{l}\text { reviewing partner must be rotated after five years, but may rotate back to their } \\
\text { previous position five years later. There is no requirement to rotate audit firms. } \\
\text { The Supervisor of Banks is empowered to require auditing firms to provide access to } \\
\text { their working papers in connection with the performance of an audit. Section } 5 \text { (b) of } \\
\text { Directive } 303 \text { permits the Supervisor to demand and use to the degree necessary any } \\
\text { information created in communication between an external auditor and anyone at the } \\
\text { banking corporation. This power has been used on rare occasions. }\end{array}$ \\
\hline Assessment & Compliant \\
\hline Comments & $\begin{array}{l}\text { The question whether to require banking corporations to rotate external auditors } \\
\text { periodically has been under consideration, but no decision has been made. Practically } \\
\text { speaking, with a minimal number of firms in Israel offering auditing services to the } \\
\text { banking industry, the rotation of external auditors may create some added } \\
\text { competition. }\end{array}$ \\
\hline Principle 23. & $\begin{array}{l}\text { Corrective and remedial powers of supervisors. Supervisors must have at their } \\
\text { disposal an adequate range of supervisory tools to bring about timely corrective } \\
\text { actions. This includes the ability, where appropriate, to revoke the banking license or } \\
\text { to recommend its revocation. }\end{array}$ \\
\hline Description & 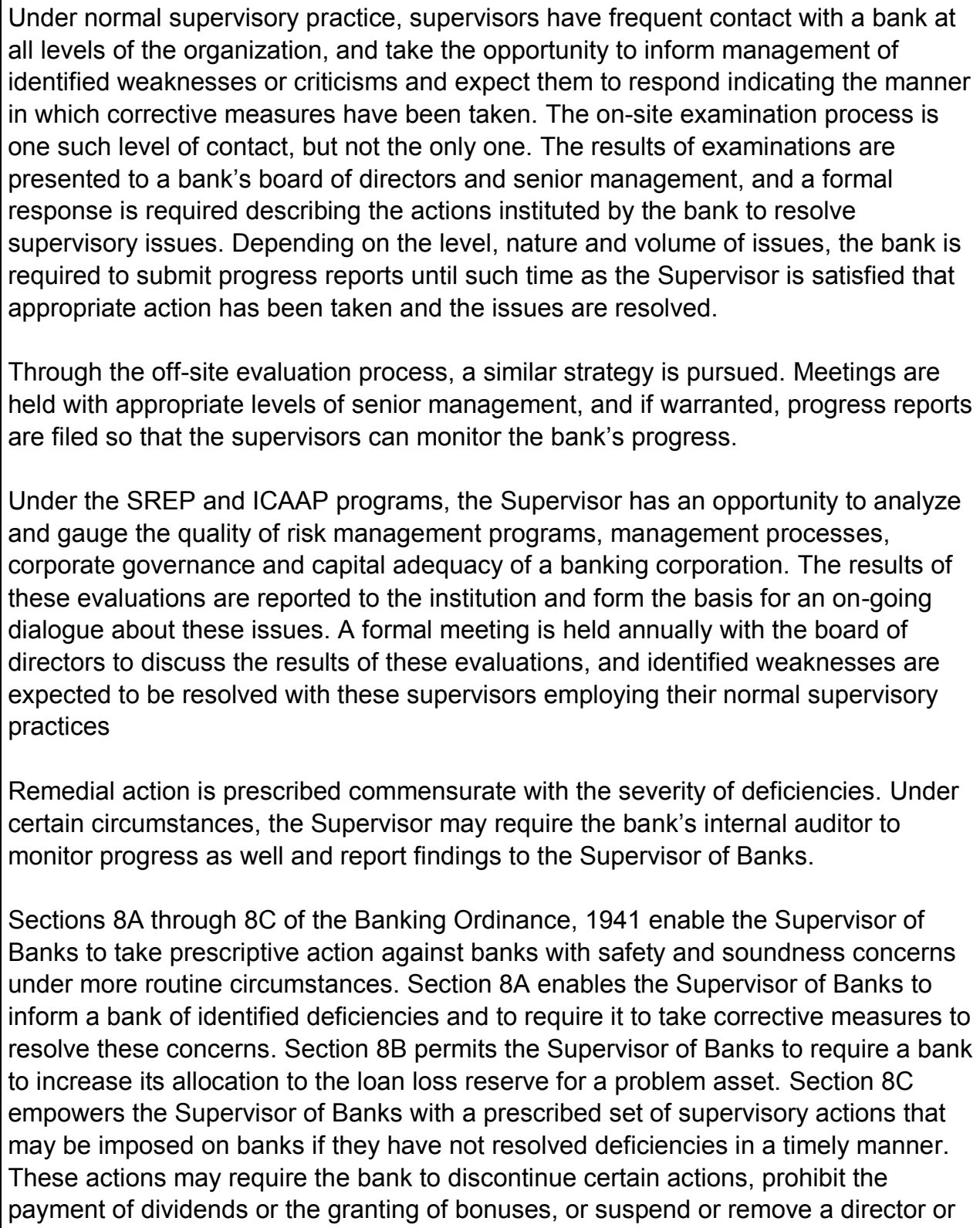 \\
\hline
\end{tabular}


officer of the bank.

In practice, the Supervisor of Banks typically pursues informal supervisory action, which has been effective in resolving safety and soundness issues. These practices take the form of meetings with bank management, monitoring programs that include progress reports and other strategies of this nature.

Under Section 8A of the Banking Ordnance, the Supervisor of Banks can require that a bank rectify "defects" when the bank "has transacted business in a manner likely to impair its ability to meet its obligations or the proper conduct of its business." In practice this has been interpreted to mean that the Supervisor can require a bank to raise capital or submit a capital plan. Directive 211 also empowers the Supervisor of Banks to address capital adequacy issues. Under this directive, a bank may be subject to enhanced monitoring of its capital position, prohibited from the payment of dividends, required to raise additional capital, or required to develop a capital plan to restore capital to a level satisfactory.

Section 8D of the Banking Ordinance, 1941, prescribes the involvement of BOI in administering a troubled bank, but only if the transaction includes the transfer of all liabilities. Under the provisions of this section, the Governor after consultation with the Supervisor of Banks, and with the approval of the Licensing Committee, may appoint an administrator to manage the bank, a special examiner to supervise the bank's management, and a management committee to advise the administrator.

The administrator is required to manage the bank in accordance with directions received from the Governor or the Supervisor of Banks, and his status is that of an executive officer in the bank. After consultation with the management committee, and with the Governor's approval he may consummate the transfer of the assets and liabilities of the bank to another bank. The special examiner is required to supervise the activities of the board of directors and manage the affairs of the institution.

In addition to sanctions applied against individuals under Section $8 \mathrm{C}$, the Supervisor of Banks has other provisions of the Ordinance at his disposal in the event penalties or sanctions are deemed necessary. For example, Section 11A of the Banking Ordinance, 1941 describes circumstances when officers can be terminated, and Section 15(a) (2) describes criminal liability for non-compliance with the ordinance. Various types and amounts of fines and penalties are enumerated in other sections of the Ordinance.

Under the Memorandum of Understanding in effect with the ISA and the Commissioner of the Capital Market, Insurance and Savings at the Ministry of Finance, and based on the Banking Ordinance, 1941 provisions, the Supervisor of Banks would be able to inform these supervisors of enforcement actions, either formal or informal, taken against a bank, and coordinate these efforts with the appropriate Israeli supervisor in the event there are subsidiaries in the banking group under their direct supervision.

\begin{tabular}{l|l} 
Assessment & Largely Compliant \\
\hline
\end{tabular}

Comments $\quad$ While BOI has not exercised its authority under Section 8D of the Banking Ordinance, 1941 since 2002, the Supervisor of Banks recognizes that the powers granted under this section are limited and need to be expanded and strengthened. In connection with their assessment of the existing law, the authorities should consider strengthening it by adding provisions that would provide $\mathrm{BOI}$ with greater flexibility.

Section $8 \mathrm{C}$ of the Ordinance is very explicit with respect to the supervisory actions that may be prescribed in the event a formal enforcement action is needed. However, such prescriptions may not necessarily be appropriate based on the deficiencies or supervisory concerns that the Supervisor of Banks may have. The list of permitted 
actions could be expanded and in any event an additional provision should be added to this section that would enable the Supervisor to apply other supervisory actions commensurate with the deficiencies in the bank. Likewise, Section $8 \mathrm{~A}$ could be enhanced by clarifying that the section authorizes actions based on any violation of law or regulations and that the $\mathrm{BOI}$ may require affirmative remedial actions.

There are no laws that explicitly guard against the Supervisor unduly delaying corrective measures against banks, but the actions of the Supervisor of Banks do not suggest that such delays exist. Nevertheless, resolution of corrective measures may in reality take a protracted period of time, especially since banks have the opportunity, under Section 8A (a) of the Ordinance, to submit its observations and objections to the identified deficiencies.

The Supervisor of Banks may take remedial actions against a bank's affiliated companies, such as a parent organization or a subsidiary when it is also supervised by $\mathrm{BO}$, and there are various provisions of the law that are intended in part to protect the bank against abusive practices. However, there is no explicit power to establish a ring-fencing mechanism as a corrective measure in the event certain types of abusive practices by affiliates occur. The authorities should consider a comprehensive regulation that governs relations with affiliates and the nature and type of intercompany transactions (See CP 24).

Although this point goes beyond the BCP, it should be noted that the law should provide a much broader form of going concern resolution by expanding significantly the power of the administrator and adding a number of resolution tools to provide flexibility in dealing with banks that have reached a level of significant deterioration but are not yet insolvent. Such provision could include some of the following: legislation to facilitate a rapid recapitalization of the bank by an administrator; a purchase and assumption scheme; legislation to require or facilitate a merger where a healthy bank is willing to take over a problem bank; a scheme of payout priorities in the event of a liquidation; the establishment of a bridge bank to extend the time to identify a qualified buyer; and, the establishment of a good bank/bad bank structure operated by a government sponsored asset management company to liquidate bad assets and resolve certain types of liabilities.

Principle 24. $\quad$ Consolidated supervision. An essential element of banking supervision is that supervisors supervise the banking group on a consolidated basis, adequately monitoring and, as appropriate, applying prudential norms to all aspects of the business conducted by the group worldwide.

Description

Israel's five largest banking institutions are conglomerates in the sense that they consist of a combination of one or more banking institutions combined with an array of non-bank financial institutions, some of which are located in Israel, and some of which are located in foreign jurisdictions. The majority of the Israeli banking system activity in foreign jurisdictions is done through branches and banking subsidiaries; only a negligible part of the activity is taking place in non-bank financial institutions. To gain an understanding of the organizational and ownership structure, and the nature and types of activities in which the components of the corporation engages, the Supervisor of Banks has the authority, under Section 5 (a) of the Banking Ordinance, 1941 to require banking corporations to provide information on the banking group, including the nature of the activities of affiliated companies, together with the ownership structure. To ensure that the activities of a banking corporation are solely banking activities or those closely related to banking, the Banking (Licensing) Law, 5741 1981 places restrictions on the types of activities in which the bank or its affiliated companies may engage, and the types of companies that the banking corporation may control. Thus, a banking corporation is limited to controlling affiliates that conduct a banking business or associated service companies, non-bank financial companies that engage in asset management or underwriting activities, an insurance agency marketing home-owners insurance, and domestic and foreign banks. As a further restriction, to establish a subsidiary, either locally or abroad, the Supervisor of Banks 
must, in most cases, grant approval to operate such an establishment, and the approval provides conditions that explicitly state the activities in which the subsidiary may engage. To expand or change its business lines, the subsidiary must receive supervisory approval. The Supervisor of Banks also is empowered to restrict the locations overseas in which activities may be conducted.

As a practical matter, so that it may have an understanding of a banking corporation's holdings, each such institution is required to file an annual report with the Supervisor of Banks indicating the entities that comprise the banking corporation, directly or indirectly, where the ownership interest is 20 percent or more. The report contains information on the activities and business lines of each affiliate, principal financial data, and the corporation's equity interest in the affiliate. Another report also requires the reporting of the banking corporation's non-financial investments. Changes in ownership, resulting from the sale, merger or acquisition of various entities, also are reported.

Under Reporting to the Public Directives, the banking corporation is required to disclose to the public in its annual report its ownership interest in affiliated companies, a description of the activities of the main companies held in the group, and some discussion of the financial condition of the principal affiliates. The supervisors, using this information and other source data, have detailed ownership structure pictorials of the banking corporations.

The supervisors rely principally on off-site activities to gain an understanding of the activities of affiliated companies. Resources employed include reviews of the financial statements of the affiliates, management reports on activities and risk management filed with the Head Office, external and internal audit reports, on-site examination reports of a host country regulator, meetings with senior management of the banking corporation responsible for activities or entities overseas, and meetings with the management of the affiliates themselves. In addition, in assessing the risks in a banking corporation, the supervisors hold meetings with executive management to discuss matters relating to the consolidated group. For each of the banking groups, the supervisors have a dedicated consolidated supervision analyst in off-site supervision supported by a team of four analysts.

The supervisors evaluate the risks in the banking corporation, both on a consolidated basis and for individual affiliated companies, based on BOl's risk-based supervision regimen (BCP 19 and 20). All material non-bank affiliates are subject to the same risk management processes as the commercial banks themselves. (A material financial subsidiary would be subject to the same risk management processes as the banking corporation. In practice however, the non-bank subsidiaries are not material.) Nonbanking activities engaged in by the banking group in asset management and underwriting are not subject to the same intensive supervision by BOI, either in Israel or abroad, because of materiality considerations and because these activities are subject to the supervision of the relevant securities authority (the ISA in Israel). ). BOI relies on the United States supervisory authorities for the supervision of these activities operated in the United States

Aside from the report on the holdings of a banking corporation, there are other supervisory reports that must be filed that provide quantifiable data emanating from risk management practices. These reports are collected under the authority of Section 5 (a) of the Ordinance and under certain directives. The directives address reporting requirements on such areas as capital measurement and capital adequacy, lending limits, concentrations of credit and exposures to related parties. The information is filed on a consolidated basis, and includes foreign branches and subsidiaries.

Information gained from host country supervisors is employed in the supervision of 
both the banking operation located in the host country and in the supervision of the banking corporation on a consolidated basis. These operations also file supervisory reports on a solo basis on their financial condition.

The principal, domestic supervisor with which $\mathrm{BO}$ must coordinate supervisory activities is the ISA, which supervises the activities of subsidiaries engaged in an asset management or underwriting business. A forum to facilitate and coordinate supervisory activities, in addition to the exchange of information, has been established recently, but it has not gained sufficient momentum so as to enable $\mathrm{BOI}$ to receive sufficient information to assess the manner in which risks in these companies are managed, or to determine issues warranting supervisory attention. Moreover, as an authority charged principally with compliance responsibilities, there are gaps in the supervision of these local activities that will have to be closed.

An understanding of the organizational structure and the review of supervisory reports represent only two of the supervisory processes under which a banking corporation's foreign operations are supervised. The linchpin to the supervision of these entities is a series of directives that requires the banking corporation to supervise its activities on a consolidated basis, and places the responsibility to do so with the board of directors. Directive 339 requires banking groups to manage and account for risk exposures for both local and foreign activities on a consolidated basis in its management information systems and that all entities must be subject to an internal audit process in which the auditor is responsible for verifying the adequacy of risk management systems at all group entities. The banking supervisors assess the nature, quality and volume of information available to senior management for its oversight of the banking corporation's activities both on an individual entity and consolidated basis, and the frequency and nature of communications. Functional reviews across the institution are conducted in which the overall performance of the board, management at various overseas operations and the internal audit are evaluated. On-site examinations of branches and subsidiaries by the host country supervisor are relied upon to complement the supervisory approach, as $\mathrm{BO}$ does not perform its own examinations overseas. To round out the supervision of a banking corporation, $\mathrm{BOI}$ meets with management of branches or subsidiaries overseas to discuss risk management or other supervisory issues when the opportunity arises. It meets at a sufficient level of frequency with foreign bank supervisors in countries where Israeli banks have a material presence relative to the size and scope of the banking corporation's operations, and has made a determination relative to the quality of supervision by host country supervisors. Management of the banking corporation is expected to be intensively involved in the risk management and control functions of a subsidiary deemed to be engaged with a higher risk profile.

To facilitate the management of a banking corporation's operations on a group-wide basis, the Supervisor of Banks recently required each such group to establish a risk management unit, usually managed by a Chief Risk Officer, whose responsibility is to evaluate the group's risk on a consolidated basis and make recommendations to the board and senior management when risk management issues are identified. The risk unit develops risk profiles and risk assessments, and monitors the adequacy of risk management practices in the consolidated organization. The Risk Officer, who is required to report directly to the board of directors, must prepare a quarterly report on the group's risk management practices, which is submitted to the group's board and to the Supervisor of Banks.

The Supervisor of Banks is empowered to revoke the permit to operate a foreign branch or subsidiary under Sections 30 (a) and 33 (a) of the Banking (Licensing) Law 5741 -1981. Section 30 (a) provides the authority for revocation in the event the Supervisor determines that there is inadequate oversight, control or monitoring of the entity by the parent institution. Section 33 (a) permits revocation if the Supervisor does 


\begin{tabular}{|c|c|}
\hline & $\begin{array}{l}\text { not receive sufficient information about the entity to supervise it satisfactorily. } \\
\text { The permit issued to operate a bank, in virtually every case, is granted to individuals } \\
\text { who may hold the bank directly, through a holding company or through other } \\
\text { corporate holdings. These individuals are referred to as the ultimate owners, and they } \\
\text { are subjected to an intensive fit and proper test. }\end{array}$ \\
\hline Assessment & Largely Compliant \\
\hline Comments & $\begin{array}{l}\text { In spite of the comprehensive approach to consolidated supervision by the authorities, } \\
\text { there is an important gap in the overall supervision of banking corporations. The gap } \\
\text { relates principally to the supervision of asset management and underwriting activities } \\
\text { in non-bank financial subsidiaries, which are supervised by the ISA, but are owned by } \\
\text { banking corporations. It is of critical importance that BOI and the ISA reach agreement } \\
\text { on the supervisory approach to these companies, and the nature and type of } \\
\text { supervisory information that will be exchanged in connection with their supervision. } \\
\text { BOI cannot take a full view of a banking corporation on a consolidated basis without } \\
\text { greater understanding of the level of risk and the manner in which risks in these } \\
\text { organizations are managed. } \\
\text { Other activities in which a bank may be engaged in, but which are embedded in a } \\
\text { bank's operations, include certain broker-dealer and trustee operations. The ISA does } \\
\text { not have any supervisory responsibilities over these activities. Certain of the larger } \\
\text { banking corporations engage in these operations overseas as well. These activities } \\
\text { have received little attention to date by the supervisors, either because the perceived } \\
\text { risk is low in light of the level of activity or because a host country supervisor provides } \\
\text { active oversight. Nevertheless, supervisors should gain a thorough understanding of } \\
\text { the level of risk and the manner in which they are managed; such operations can be } \\
\text { the source of large losses. } \\
\text { With more intensive scrutiny of liquidity on a consolidated basis in connection with the } \\
\text { Basel III Accord, the current approach to supervision of liquidity will have to be altered } \\
\text { so that a more global approach for each banking corporation will have to be } \\
\text { developed. }\end{array}$ \\
\hline Principle 25. & $\begin{array}{l}\text { Home-host relationships. Cross-border consolidated supervision requires } \\
\text { cooperation and information exchange between home supervisors and the various } \\
\text { other supervisors involved, primarily host banking supervisors. Banking supervisors } \\
\text { must require the local operations of foreign banks to be conducted to the same } \\
\text { standards as those required of domestic institutions. }\end{array}$ \\
\hline Description & $\begin{array}{l}\text { The five large Israeli banking corporations all have a network of operations located in } \\
\text { foreign countries, necessitating the establishment of home-host relationships. Such } \\
\text { relationships are particularly important with regulators in the United States, the United } \\
\text { Kingdom and Switzerland, which host the preponderance of Israeli banks' overseas } \\
\text { operations, and the relationships are governed by either formal or informal } \\
\text { arrangements that facilitate contact between regulators as frequently as needed. } \\
\text { There are five foreign banks with operations in Israel, but in aggregate, these } \\
\text { operations are immaterial to the size of the Israeli banking system and to the parent } \\
\text { institution. As a result, the frequency and level of contact is far less. } \\
\text { Formal written arrangements exist with regulators in the United States and the United } \\
\text { Kingdom. BOI and the Federal Reserve and the FDIC are signatories to a } \\
\text { Memorandum of Understanding that governs the cooperative arrangements between } \\
\text { the supervisors. Under the Memorandum, arrangements have been concluded for the } \\
\text { exchange of information on the operations of Israeli banks operating in the United } \\
\text { States and US banks operating in Israel, and for other relevant cooperative efforts. } \\
\text { The formal arrangement with the United Kingdom takes the form of an exchange of } \\
\text { letters under which, inter alia, the UK supervisor provides information on liquidity } \\
\text { positions and facilities to BOI on Israeli banks operating in the United Kingdom. }\end{array}$ \\
\hline
\end{tabular}




\begin{tabular}{|c|c|}
\hline & 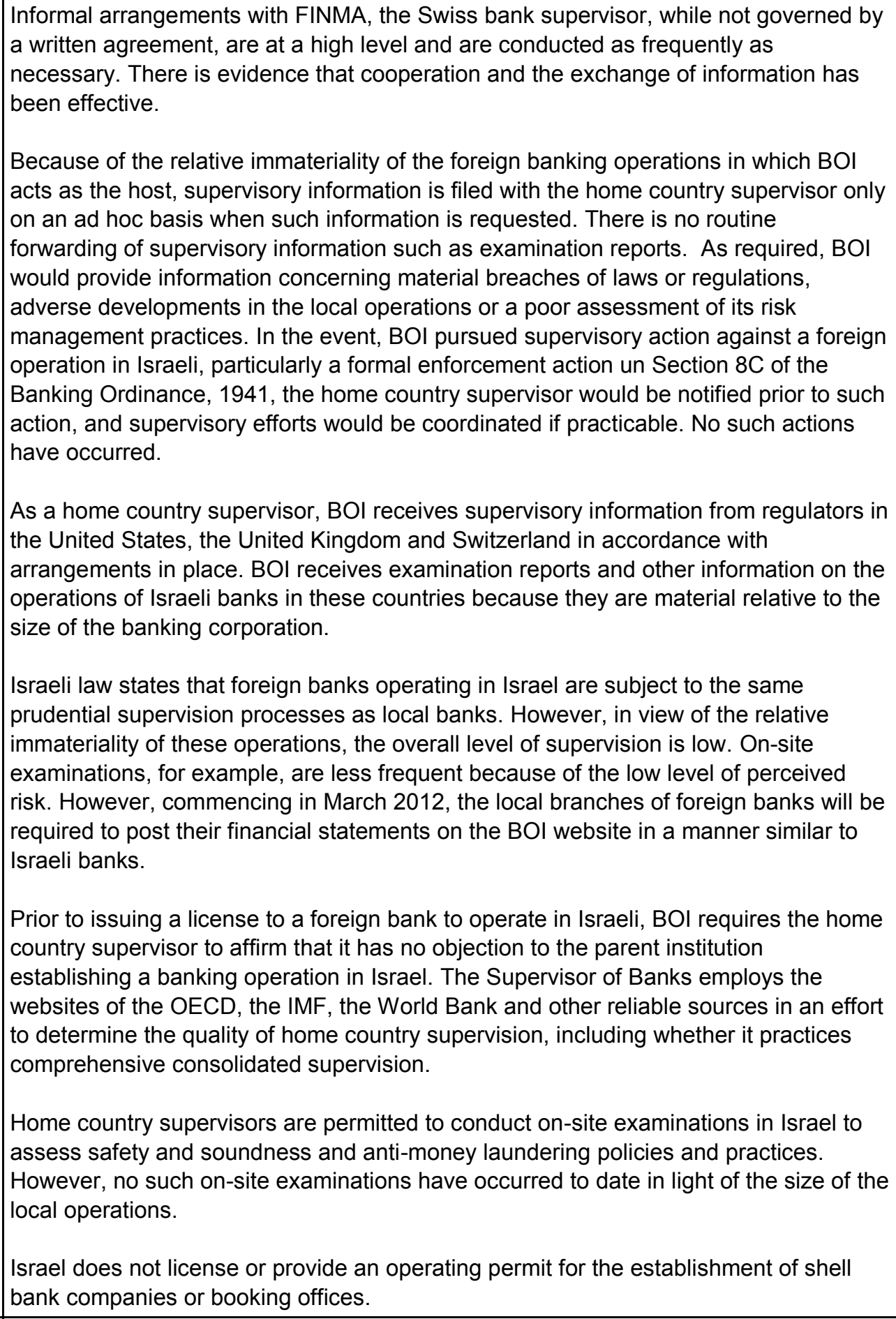 \\
\hline Assessment & Compliant \\
\hline Comments & $\begin{array}{l}\text { While the existing arrangements for the exchange of information with the United } \\
\text { Kingdom have proven to be satisfactory, the authorities may wish to explore } \\
\text { expanding the types of information that is exchanged under the current formal } \\
\text { agreement. EU restrictions on full information exchanges without a formal MOU may } \\
\text { inhibit the complete sharing of information without such a formal mechanism. } \\
\text { The BOI should consider whether it should engage more actively in the supervisory } \\
\text { colleges for foreign banks that it hosts, and whether it should set up colleges for Israeli } \\
\text { banks that have relatively large foreign operations. } \\
\text { A foreign bank operating a wholly-owned banking subsidiary in Israel is under a }\end{array}$ \\
\hline
\end{tabular}


resolution strategy in its home country, and there has been no outreach to date by the home country supervisor. The authorities should consider contacting the home supervisor and inquiring about its strategy relative to its overseas operations, especially its Israeli operations, and attempt to coordinate supervisory efforts during the resolution, so far as is practicable, with respect to the local subsidiary. Contacts of this nature would be in keeping with the policy of having contact with a home country supervisor on an ad hoc basis as circumstances dictate. An on-site visit by a BOI examiner to assess its operations also should be considered. 